Portland State University

PDXScholar

Summer 9-21-2017

\title{
A Conservationist Takes Flight: the Early Career of William Lovell Finley, 1887-1911
}

Carey Elizabeth Myles

Portland State University

Follow this and additional works at: https://pdxscholar.library.pdx.edu/open_access_etds

Part of the History Commons

Let us know how access to this document benefits you.

Recommended Citation

Myles, Carey Elizabeth, "A Conservationist Takes Flight: the Early Career of William Lovell Finley, 1887-1911" (2017). Dissertations and Theses. Paper 3830.

https://doi.org/10.15760/etd. 5724

This Thesis is brought to you for free and open access. It has been accepted for inclusion in Dissertations and Theses by an authorized administrator of PDXScholar. Please contact us if we can make this document more accessible: pdxscholar@pdx.edu. 
A Conservationist Takes Fight:

The Early Career of William Lovell Finley, 1887-1911

by

Carey Elizabeth Myles

A thesis submitted in partial fulfillment of the requirements for the degree of

\section{Master of Arts}

In

History

Thesis Committee:

David A. Johnson, Chair

Catherine McNeur

William L. Lang

Barbara Brower

Portland State University

2017 
(C) 2017 Carey Elizabeth Myles 


\begin{abstract}
William Lovell Finley was an American conservationist active in Oregon and California from 1894 to 1947 . He was president of the Oregon Audubon Society and a field representative for the National Audubon Society. He also served as Oregon State Game Warden, State Biologist and as a Commissioner on the Oregon State Fish and Game Commission. He wrote for ornithology journals and popular magazines, was an early wildlife field photographer, and made wildlife films. This thesis examines the Finley's career from 1887 to 1911 to demonstrate how Finley, as a self-taught naturalist, forged a professional identity and became part of a social and professional network of conservationists. Using Finley's correspondence and published pieces the thesis presents a detailed account of his photography partnership with Herman T. Bohlman, a Portland plumber and artist, and of Finley's involvement in three ornithology organizations, the Northwest Ornithology Association, the Cooper Ornithological Club, and the National Audubon Society.
\end{abstract}




\section{Acknowledgements}

My path to completing this thesis was long and circuitous, and I was not the only one who had to stay the course. I am grateful to my family and friends for patience and support, especially my dad who introduced me to birds, Yasmeen for role-modeling persistence, Zari for serene confidence in me when I had very little, and Mir for dinners, dancing, and drives in the Saab. Archivists and reference librarians are the best, and among the best are Scott Daniels of the Oregon Historical Society and Ruth Vondracek at Oregon State University Special Collections and Archives. Laura Cray and Mattieu Deschaine at the Oregon Historical Society have worked over the past year to digitize Finley-related material and make it available on-line, which made the final stages of this project infinitely easier. I am also grateful to Worth Mathewson who was generous with time, information, and materials, and Taylor Rose who provided a shot of encouragement and timely feedback at just the right moment. The members of my thesis committee provided thoughtful comments and suggestions on how this thesis could be strengthened and deepened. I am especially indebted to Bill Lang who brought William Finley to my attention, and to David Johnson, who was cheerfully demanding and supportive in just the right measures. 


\section{Table of Contents}

$\begin{array}{lr}\text { Abstract } & \text { i } \\ \text { Acknowledgments } & \text { ii } \\ \text { List of Figures } & \text { iv }\end{array}$

Introduction $\quad 1$

William Lovell Finley

Chapter One 14

Camera Hunting: William L. Finley and Herman T. Bohlman 1887-1903

Chapter Two 45

Flocking Together: Finley and Ornithology Organizations 1894-1910

Chapter Three $\quad 72$

Farther Afield: Finley and Bohlman 1904-1908

$\begin{array}{ll}\text { Epilogue } & 109\end{array}$

Fully Fledged: Finley’s New Direction 1910-1911

ii

v




\section{List of Figures}

Fig. 1 Setting up camp on the Lewis River

Fig. 2 Chickadees

Fig. 3 "Rufous at home"

Fig. 4

"Six of the frowzy-headed kingfishers...."

Fig. 5

"The first day out of the nest...."

Fig. 6 Photographing kingfishers

Fig. $7 \quad$ Wading to the hawks' nest

Fig. 8

With flickers

Fig. 9 "Photographing the Flickers' nest"

Fig. $10 \quad$ Setting up the shot

Fig. 11 Bohlman climbs the "bridge" tree

Fig. 12

Bohlman with camera

Fig. 13 Climbing to the hawks' nest

Fig. 14 Young hawks standing on edge of nest

Fig. 15

Heading to the Oregon coast

Fig. 16

Puffin in Burrow

Fig.17 Camped on Three Arch Rocks

Fig. 18 Reaching the murres

Fig. 19 Hummingbird feeding on the wing 
$\begin{array}{lll}\text { Fig. } 22 \quad \text { Barn owl nest and eggs } & 77\end{array}$

$\begin{array}{lll}\text { Fig. 23 Barn owl chicks on a box } & 77\end{array}$

$\begin{array}{lll}\text { Fig. } 24 & 78\end{array}$

Fig. $25 \quad$ Grebe collecting: cutting off wings 81

Fig. $26 \quad$ Grebe collecting: opening skin down the back 81

Fig. 27 Grebe collecting: scraping the skin 82

Fig. 28 Grebe collecting: wings at the chopping block 82

Fig. $29 \quad$ Pelicans investigate umbrella blind 84

$\begin{array}{lll}\text { Fig. } 30 \quad \text { Finley photographing pelicans } & 84\end{array}$

$\begin{array}{llr}\text { Fig. } 31 \quad \text { Young pelican } & 85\end{array}$

$\begin{array}{lll}\text { Fig. } 32 & \text { Pelican rising from the water } & 85\end{array}$

Fig. 33 Bohlman walking with pelican 86

Fig. $34 \quad$ Condor egg on a ledge nest 89

Fig. 35 The condor chick newly hatched 90

$\begin{array}{lll}\text { Fig. } 36 & \text { The condor pair with chick }\end{array}$

Fig. 37 The condor "General" in camp, Jennings Lodge, Oregon 97

Fig. $38 \quad$ Irene Finley playing tug-o-war with General 98

Fig. 39 Bohlman with General in Portland 99

$\begin{array}{lll}\text { Fig. } 40 & \text { Bohlman at the wheel } & 102\end{array}$

$\begin{array}{lll}\text { Fig. } 41 \quad \text { Bohlman carrying a canvas boat } & 103\end{array}$

$\begin{array}{lll}\text { Fig. } 42 & \text { Finley sitting on a muskrat house } & 104\end{array}$

$\begin{array}{lll}\text { Fig. } 43 \quad \text { California gulls flying } & 105\end{array}$

$\begin{array}{ll}\text { Fig. } 44 \quad \text { Dead grebe with chicks } & 106\end{array}$ 


\section{Introduction \\ William Lovell Finley}

American conservationist William Lovell Finley appears in the historical record of the early twentieth century in a bewildering variety of roles. He was a daring young photographer, high in the trees overlooking San Francisco Bay. As president of the Oregon Audubon chapter and deputy state game warden, he embarrassed downtown Portland milliners - arresting them for using illegal feathers on their hats. He can be found calculating hunting license revenue, putting elk on sleds in Eastern Oregon and teaching Boy Scouts to build bird houses. He strategized on national wildlife legislation, advocated for clean rivers and campaigned relentlessly for bird refuges in the Klamath and Malheur basins. He had a way with words. He made movies. He kidnapped a California condor, and dressed up as a mountain goat. ${ }^{1}$

Most assessments of Finley have focused on individual elements of his work, but before evaluating his impact one must examine the whole of it. This thesis begins this process, using Finley's correspondence and early published work to reconstruct how he began his career and reflect on the relationships among his different activities. During the period between 1887 to 1911, Finley grew from a bird-obsessed boy to a noted popular naturalist and expert amateur ornithologist, recognized for his contributions to the field

${ }^{1}$ William L. Finley and Arthur Newton Pack, Getting Our Goat, digitized from film reels, William L. Finley Papers, 1899-1946 (MSS Finley), Oregon State University Special Collections and Archives Research Center, Corvallis, Oregon. https://oregondigital.org 
by professional scientists and wildlife managers. From his teens to early thirties, he lay his career's foundation with a variety of work, the heart of which was his photography partnership with childhood friend Herman T. Bohlman. Their photography expeditions are described in chapters one and three of this thesis. Finley was also active during this time in several ornithology organizations, honing skills in organizing and leadership, and developing important social and professional connections, as explained in chapter two. The thesis ends in 1911 when Finley, at age thirty-four, took on his first full-time professional job as Oregon State Game Warden.

Finley did not take a typical career path for a naturalist of the period, when the trend was toward professionalization in science and wildlife management. Those who were self-trained faced barriers to moving beyond amateur status. Finley studied history and philosophy, not biology, at university. Yet despite being largely self-taught as a naturalist, Finley worked in broad areas encompassing popular media, wildlife management, science, lobbying, and activism. His career took him back and forth between these different activities for decades. If not for his relentless persistence on the issue of bird protection, Finley might seem, in fact, a little flighty.

When examined together, though, it becomes clear that Finley's various activities supported and reinforced each other. In this way, Finley created his own credentials in lieu of professional training. He was a thoughtful observer of wildlife and produced quality photography, deft writing, and entertaining and informative lectures. These, combined with his skill in collaboration, gave him an entrée into the overlapping communities of ornithology and professional wildlife management. Once accepted, he 
used his connections to gain better opportunities to take photos, share them, and later to influence wildlife management and protection. Finley established this pattern of working while still a university student and continued it throughout his life.

Careful examination of Finley's life and work is an opportunity to improve our understanding of the evolution of American ideas about wildlife and the environment. His story illuminates the social and professional networks through which significant ideas and practices in American conservation developed at the turn of the twentieth century. Finley worked through social and professional connections to further his aims in conservation, creating alliances with prominent actors in the American conservation movement. He placed himself in a position to learn from and to influence the thinking of policy makers, scientists, and wildlife professionals on man's relationship with nature. Through his photography, writing, and filmmaking he also disseminated to the general public emerging ideas about the need to protect wild things and places, and how to both encourage and regulate people's access to nature.

In addition, Finley's work anticipated current practices in conservation, including tensions that remain in today's efforts to protect wildlife. His conservation work encompassed contradictions and left sometimes conflicting legacies. For example, he is celebrated as a founder of both the Portland Audubon Society and the Oregon Department of Fish and Wildlife. These institutions are today occasionally at odds with 
one another over how best to manage Oregon's wildlife, but their current missions can in each case be traced back to Finley's goals and work between 1887 and $1911 .^{2}$

The current funding crisis in state wildlife management is in part a result of decisions made by early wildlife managers such as Finley. Finley's recognition of the importance of habitat put him at the forefront of the development of the partnership between sportsmen and conservationists. As Oregon State Game Warden, he saw hunters and anglers as natural allies in the conservation movement, especially as a source of revenue for state wildlife management. Hunting and angling license fees have enabled the creation of state fish and wildlife departments across the country, but have affected the mission of those agencies and left them vulnerable when sport hunting declined. ${ }^{3}$

Finley also helped forge a path for later popular science communicators and citizen scientists. His photography, filmmaking, and popular writing were precursors to current packaging of conservation messages and education as entertainment. Finley

\footnotetext{
${ }^{2}$ Conflicts between Portland Audubon and Oregon Department of Fish and Wildlife should not be overstated. The two organizations often work together, recently for instance, to educate the public on living with urban wildlife and to create management plans for threatened or endangered species (i.e. the Streaked Horn Lark). Portland Audubon has supported ODFW's efforts to modernize its income stream(s) through a new tax. Like fish and wildlife agencies in other states that developed funding models based on recreational hunting and fishing, ODFW has suffered from declining revenues as participation in sport hunting has fallen off. Portland Audubon has supported proposed taxes on bird seed and binoculars. However, Portland Audubon has also pressured ODFW to strengthen some of its programs, such as protections for forage fish at the coast, and has vehemently objected to ODFW trapping practices and efforts to reduce doublebreasted cormorant predation of salmon through culling of birds.

${ }^{3}$ Hunting and fishing rates have dropped substantially since the 1970s, although they have stabilized in the last 10 years. According to U.S. Fish \& Wildlife, $24 \%$ of the U.S. population fished for sport and $9.9 \%$ hunted in 1975. The 2011 National Survey of Fishing, Hunting, and Wildlife-Associated Recreation found participation rates of $14 \%$ for fishing and $6 \%$ for hunting. Those numbers represented a slight increase over 2006 participation rates. In the 1970s in Oregon 1 in 4 residents fished and 1 in 7 hunted, compared to 1 in 8 and 1 in 17 today. See U.S. Department of the Interior, U.S. Fish and Wildlife Service, and U.S.

Department of Commerce, U.S. Census Bureau, 2011 National Survey of Fishing, Hunting, and WildlifeAssociated Recreation; State of Oregon Secretary of State Audit Report, Oregon Department of Fish and Wildlife: Financial Condition Review, Report Number 2015-09, April, 2015.
} 
preceded others in attempting to balance entertaining stories and visuals with serious information and appeals. Ornithology as a science struggled with the role of amateurs during the period in which Finley was active. Finley and Bohlman's 1906 series of a California Condor mating pair and offspring, produced at a time when the species' extinction seemed all but inevitable, exemplified the value of contributions amateurs made.

Finley has been portrayed as a bird-lover, a passionate activist on behalf of wild places and clean water, exploitive of wildlife in the name of science or entertainment, stubborn and strident, a canny deal-maker, elitist, and popular. He was all of these. Finley fought hard for protected places, recognizing early that education and hunting regulations were insufficient unless nesting grounds and other important bird areas were maintained as refuges for birds. His passion for protection stemmed in no small part from his memory of childhood wonderment of birds passing overhead along the Pacific Flyway and his later experiences at the Klamath and Malheur nesting grounds. Still, he wasn't sentimental or romantic about wildlife. ${ }^{4}$ He supported sport hunting, though he seldom hunted himself. While photographing birds was less destructive than shooting them, Finley and his partners used invasive tactics. He and his partners did not hesitate to uncover nests, handle chicks, or tame wild animals as pets. He was also a firm believer in

\footnotetext{
${ }^{4}$ Years after his 1903 trip with Bohlman to photograph nesting birds on Three Arch Rocks on the Oregon Coast, Finley wrote that they had enjoyed Murre and Cormorant eggs, in omelets and hard-boiled. William L. Finley, "Hunting Birds with a Camera: A Record of Twenty Years of Adventure in Obtaining Photographs of Feathered Wild Life in America," National Geographic (August 1923): 182, 185.
} 
collecting specimens in the interest of scientific advancement. His conservationism was rooted in a destructive boyhood hobby of collecting eggs.

Finley's family background allowed Finley to pursue birds, both in the field and as a calling. With a firm footing in middle-class prosperity, Finley forged connections across a range of social classes. Owing to his father's success, he was able to attend university and thus enter into a network of elites. Finley's father began as a carpenter's apprentice and built a thriving business. Although Finley worked hard he was given the freedom to find his own way. Growing up in the West also allowed Finley the conservationist to emerge as he did. He had access to the outdoors on his grandparents' property in Northern California, and later, the wild areas and wildlife in and around turn of the century Portland, Oregon. Finley promoted an image of himself and early partner Bohlman as an intrepid duo, chasing birds in new territory with their cameras, and this played well with established ornithology organizations in the East.

Finley was born in 1876 in Santa Clara County, California, and was from the beginning fascinated by birds. In 1887 he moved with his family to Portland, Oregon, where he and Bohlman collected bird specimens, nests and eggs. In their twenties, the two turned to field photography. At the turn of the century this was a challenging endeavor, requiring heavy equipment, glass plates, and technical ability. Finley and Bohlman hauled their gear up trees, on horseback, and in boats. Some of the remarkable photographs they obtained influenced President Theodore Roosevelt's selection of wildlife refuges in the West. After attending the University of California Berkeley, Finley wrote about birds for magazines and newspapers, illustrated with photographs he and 
Bohlman took. In the 1900s, as field agent for the National Audubon Society and early leader of the Oregon Audubon chapter, Finley expanded Audubon's influence in the West. In 1906, at the age of thirty, he married Irene Barnhart. He wrote several popular books with his wife, who often joined him in the field. ${ }^{5}$ The Finleys began making short wildlife films in the 1910s. Between 1911 and 1930 Finley worked in various capacities for the State of Oregon's Game Commission (later Oregon Department of Fish and Wildlife). In the 1920s and 1930s he made wildlife films with Irene and partner Arthur Pack of the American Nature Association. After suffering several debilitating strokes in the mid-1940s, Finley died in 1953.

Because he had a colorful career and personality, he is frequently mentioned in a variety of contexts related to the history of conservation in Oregon. However, his career has received limited comprehensive examination. Among key sources, Worth Mathewson provides the fullest treatment of Finley's life to date, with a generous number of FinleyBohlman photographs as well as information gathered through interviews with family members and friends. ${ }^{6}$ Other secondary sources directly related to the time period covered in this thesis include George Jobanek's history of the Northwest Ornithological Association of the 1890s, which includes description of young Finley's leadership role in that organization. ${ }^{7}$ Several authors on California condors have included discussion of

\footnotetext{
${ }^{5}$ William Lovell Finley, American Birds, Studied and Photographed from Life (New York: C. Scribner's Sons, 1907); William L. Finley, Irene Finley, and R. Bruce Horsfall, Little Bird Blue (Boston: Houghton Mifflin, 1915); William L Finley and Irene Barnhart Finley, Wild Animal Pets (New York ; London: Charles Scribner's Sons, 1928).

${ }^{6}$ Worth Mathewson, William L. Finley, Pioneer Wildlife Photographer (Corvallis, Or.: Oregon State University Press, 1986).

${ }^{7}$ George A. Jobanek, “The Northwestern Ornithological Association," Oregon Birds: The Quarterly Journal of Oregon Field Ornithology 24 (Spring 1998): 11-17.
} 
Finley's 1906 condor photography series, including Noel and Helen Snyder, Mark V. Barrow Jr., Robert M. Wilson, Etienne Benson and Peter Alagona. ${ }^{8}$

Finley worked for the Oregon Fish and Game Commission from 1911 to 1919, just after this thesis concludes, and later served as a Commissioner. Finley's wildlife management is mentioned in Larry Maring Rymon's dissertation on wildlife conservation in Oregon, in particular a 1912 elk restoration project in Wallowa County, Oregon. ${ }^{9}$ Lawrence Lipin used Finley's own writings in the Oregon Sportman, a magazine Finley created while State Game Warden, to show how Finley, along with other Progressive conservationists, represented an elitist perspective on protecting nature. ${ }^{10}$ Peter Alagona uses Finley as an example of wildlife managers who argued for the necessity of interagency cooperation. ${ }^{11}$

One of Finley's early successes was securing the designation of the Lower Klamath Wildlife Refuge; however, the Klamath Reclamation Project severely impacted the refuge almost immediately. William G. Robbins emphasized Finley's efforts to protect Klamath Basin nesting grounds, as well as later work to call attention to the

\footnotetext{
${ }^{8}$ Noel and Helen Snyder, The California Condor: A Saga of Natural History and Conservation (San Diego: Academic Press, 2000); Mark V. Barrow, Nature's Ghosts: Confronting Extinction from the Age of Jefferson to the Age of Ecology, (Chicago; London: University of Chicago Press, 2009); Robert M. Wilson, Seeking Refuge: Birds and Landscapes of the Pacific Flyway, (Seattle: University of Washington Press, 2010); Etienne Benson, "Endangered Birds and Epistemic Concerns: The California Condor," in Endangerment, Biodiversity, and Culture, ed. by Fernando Vidal and Nélia Dias (New York: Routledge, 2016); Peter S. Alagona, After the Grizzly:Endangered Species and the Politics of Place in California (Berkeley: University of California Press, 2013): 144-145.

${ }^{9}$ Larry Maring Rymon, “A Critical Analysis of Wildlife Conservation in Oregon” (Ph.D. dissertation, Oregon State University, 1969).

${ }^{10}$ Lipin, Lawrence M. Workers and the Wild: Conservation, Consumerism, and Labor in Oregon, 1910-30, (Urbana: University of Illinois Press, 2007).

${ }^{11}$ Alagona, After the Grizzly, 70.
} 
degraded state of the Willamette River. ${ }^{12}$ Nancy Langston described Finley's bitterness that the federal government did not protect the Klamath and Malheur bird refuges and his calculated use of rhetoric to drum up support for wildlife. ${ }^{13}$ Doug Foster also discusses Finley's role in the creation and management of the refuges in the Klamath Basin, while Stephen Mark relates Finley's later fight to revive Lower Klamath Lake. ${ }^{14}$

Robert M. Wilson claims the Finley and Bohlman 1905 Klamath Basin photographs exemplify Finley's efforts to show wild places as accessible and inviting. ${ }^{15}$ Finley's later filmmaking has received some attention in surveys of early wildlife films. Gregg Mitman analyzes Finley's films of the 1920s and '30s, noting themes of domestication and appropriation of wildlife to sell nature tourism. For the cover of his second edition Mitman used a photograph of Finley and his pet bear cubs Cuffy and Tuffy. ${ }^{16}$ Palle B. Petterson also describes Finley’s filmmaking strategies to evoke sympathy and interest in wildlife, such as the inclusion of pets like the bear cubs, along with the Finleys' children, as well as skillful editing to bring out humor and narrative. ${ }^{17}$

\footnotetext{
${ }^{12}$ William G. Robbins, The Oregon Environment: Development vs. Preservation, 1905-1950 (Corvallis: Oregon State University, 1975). Finley also appears briefly in Robbins, Landscapes of Promise: The Oregon Story, 1800-1940 (Seattle, Wash.: University of Washington Press, 1997).

${ }^{13}$ Nancy Langston, Where Land \& Water Meet : A Western Landscape Transformed (Weyerhaeuser Environmental Books. Seattle: University of Washington Press, 2003).

${ }^{14}$ J. Doug Foster, "Necessary co-existence: Lower Klamath and Tule Lake Wildlife Refuges, Part I and Part II" in Shaw Historical Library, Wings That Fill the Sky: America's First Waterfowl Refuge (Klamath Falls, OR: Shaw Historical Library, 2008); Stephen R. Mark, "Conflict and Compromise: William L. Finley and the Revival of Lower Klamath Lake" in Wings That Fill the Sky.

${ }^{15}$ Wilson, Seeking Refuge, 51-54.

${ }^{16}$ Gregg Mitman, Reel Nature: America's Romance with Wildlife on Film (Seattle: University of Washington Press, 2009).

${ }^{17}$ Palle B. Petterson, Cameras into the Wild A History of Early Wildlife and Expedition Filmmaking, 18951928 (Jefferson: McFarland \& Company, 2011).
} 
Emphasizing how Finley used his personal, professional and social connections to further his goals, the thesis proceeds in a rough chronology, reflecting how Finley's photography and organization work supported one another. Chapters one and three are two parts of the story of Finley and Bohlman in the field, while chapter two overlaps these two chapters in time and focuses on Finley's organization work. Finley used their photography as the basis for his writing and lectures. Despite his amateur status, the quality of the work commanded attention in ornithology organizations such as the California Cooper Club and the National Association of Audubon Societies. Finley took advantage of the connections he made in these groups to find more prospects for field photography. His experience in the field gave him credibility in the eyes of professional scientists and wildlife managers he met through these groups, enabling him to take on greater responsibility in the sphere of policy and legislation. The pattern of supporting his policy efforts with creative work and outreach, and vice versa, continued throughout his life and put Finley at the center of developments in American conservation.

Chapter one, “Camera Hunting,” follows Finley and Bohlman from 1887 to 1903 as they begin their photography partnership. For Finley, photography initially was a way to capture and collect birds without harming them, and a pursuit through which he could build his knowledge of wildlife, as well as tangible proof of that knowledge. In many ways, the photographs Finley and Bohlman took were foundational to his conservation career. The chapter ends with one of their early triumphs, a trip out to Three Arch Rocks on the Oregon Coast that resulted in Roosevelt's designation of the Rocks as the first 
national wildlife refuge in the West. Finley saw the potential for photography as a means to advocate for bird protection, as well as the basis for a naturalist career.

Chapter two, "Flocking Together," examines Finley’s involvement between 1894 and 1910 in three key organizations that enabled him to develop standing in the ornithology community, make social connections with professionally trained ornithologists, and gain access to resources he could direct toward the promotion of conservation, especially bird protection. Finley demonstrated an ability to communicate, to persuade, and to lead, early in life. As a teenager in 1894 , he was a founding member of the Northwest Ornithological Association; in 1902 this group became the core of the Oregon chapter of Audubon. With Audubon, he pushed for laws protecting wildlife, implemented those laws, and worked in education and outreach. Under the auspices of the National Audubon Society, in 1904 Finley began lecturing throughout the country, illustrating his talks with glass plate slides of photographs he and Bohlman had taken. From 1900 to 1910 Finley was also an important figure in the Cooper Ornithology Club of California, which he joined while a college student at the University of California Berkeley. Through the Cooper Club he developed relationships with scientists such as Joseph Grinnell, and with ornithologists nationally.

Chapter Three, "Farther Afield," returns to the partnership of Finley and Bohlman from 1904 to 1908 as the men, moving into adulthood, become more ambitious, seeking out rarer species and emphasizing the documentation of species life cycles. With connections through Audubon and the Cooper Club, the scope of their photography expeditions expanded. They learned of nesting areas with potential for photography, 
especially in California. Audubon partially funded photography and site inspections in the Klamath and Malheur nesting areas in Southern Oregon. Finley married in 1906 and Bohlman in 1908. Bohlman became increasingly involved in family life after his marriage. He ran his family plumbing business, expressed himself through oil painting, and was no longer available for field and photography work. However, Finley continued taking photographs and later began making films with his wife, who accompanied him in the field.

The epilogue focuses on 1910-1911, a transitional time for Finley. Later in life, Finley became wealthy enough to build a large country home on the banks of the Willamette River, but in 1910 he and his wife were living in a cabin on the property. Finley's letters at the time reveal a man determined to make a living and preoccupied with money. Although his first book, American Birds (1907), was well-reviewed, he had difficulty finding outlets for his articles and was short of new material. He was frustrated with the limitations of his Audubon role. Moreover, his experience directing wardens for Audubon in bird refuges in Oregon and in pushing for legal wildlife protection had given him ideas about wildlife management he was eager to implement.

When Oswald West became Governor of Oregon in 1911, Finley first helped West design the new state game commission West created, then joined as a commissioner, then resigned, having convinced the other commissioners to hire him as the State Game Warden. This position launched him into a new phase of his career as a civil servant and professional wildlife manager. Finley was poised to take on a new role. He had helped achieve greater appreciation among established East Coast-based 
institutions, such as the National Audubon Societies and the American Ornithologists Union, of the importance of the West in conservation and ornithology. He had also made a name for himself as a popular naturalist through his writing, photography and lecturing, and soon would add filmmaking to his repertoire. In short, he had become a professional conservationist, fully fledged. 


\section{Chapter One}

Camera Hunting: William L. Finley and Herman T. Bohlman 1887-1903

When William Lovell Finley was eleven years old, his family left Santa Clara

County, California, where his extended family had settled a generation earlier, and

moved north to Portland, Oregon. A budding oologist, or egg collector, Finley packed up

his collection of bird eggs and nests to take along. ${ }^{1}$ He was fortunate in his neighbors in

his new home, and became friends with Herman T. Bohlman, a boy about four years

older who also collected eggs and other specimens, such as bird skins, and dabbled in

taxidermy. The two spent years together exploring the outdoors in and around Portland, and later farther afield, hunting to collect bird skins and eggs, honing skills in

observation, and building up considerable knowledge of bird behavior. By 1897 the two became interested in photography. Bohlman quickly excelled at it, and this added a new dimension to their field studies. They pushed one another to do their best possible work, and together, Finley and Bohlman took many excellent photographs.

\footnotetext{
${ }^{1}$ Oology refers to the study or collection of bird eggs. Egg collecting began as an approach to the study of birds. By the late nineteenth century egg collecting was a popular hobby, especially in the United States and United Kingdom, and was still considered an acceptable scientific practice in the field of ornithology. However, egg collection fell out of favor in the early twentieth century due to concerns regarding conservation, and collection and trade of eggs was outlawed. The collections of many individual collectors have been added to collections of natural history museums, where they are still used for research. The Western Foundation of Vertebrate Zoology in Camarillo, California claims to have the world's largest collection, about one million individual eggs. This collection and others were instrumental in determining the impact of DDT on bird reproduction in the 1960s.
} 
The photographs, and the lectures and writing Finley produced based on them, allowed him to demonstrate his expertise as a naturalist in the absence of formal training, and to argue for the value of birds to a general audience. The field work involved in obtaining them convinced him of the importance of setting aside habitat, in addition to regulation of hunting. Field photography was fundamental to his development as a conservationist. It was also a starting point for an unconventional career.

The camera and challenge of getting good shots fulfilled Finley's childhood impulse to collect. In 1901 Finley claimed the oologist's experience lacked "the charm in getting a good picture" and that the value of a good image to the photographer stemmed in part from the challenges overcome in obtaining it. Finley listed among these challenges the need for a background that displayed rather than camouflaged the bird's characteristics, the need for light, the difficulty of catching birds in a place where it is possible to set up a camera, and the likelihood of a bird moving when attempting a time exposure. ${ }^{2}$ Photographs, like specimens, also were a tangible proof of time and effort spent learning about birds and their habits. Years later, Finley wrote "an eagerness for the chase that has been fully satisfied in hunting and shooting with a camera," but also "a lasting joy that has come with the quiet chances to study at bird homes and learn the real character and individuality in these wild children of nature."3

Finley was energetic, quick, and outspoken, easily able to persuade and organize people. He also had a way with wildlife and learned to approach and handle animals,

\footnotetext{
${ }^{2}$ William L. Finley, “Catching Birds with a Camera,” The Condor 3 no. 6 (1901): 137-39.

${ }^{3}$ William L. Finley, "Hunting Birds with a Camera: A Record of Twenty Years of Adventure in Obtaining Photographs of Feathered Wild Life in America," National Geographic, (August 1923): 160.
} 
especially birds. Bohlman was reticent and mechanically inclined—good with tools, machines and materials. They both loved being out of doors and the challenges of hunting with a camera. They also shared a lively sense of humor. Regarding their field expeditions, one can easily imagine Finley chatting up the locals for tips on where to look for birds, especially nesting locations, and acting as bird whisperer, while Bohlman handled the technical details of the photography, figured out how to get themselves and their gear up cliffs and trees, and in later years, kept the car running. ${ }^{4}$

As sons of successful businessmen, Finley and Bohlman had leisure time to dedicate to their efforts as amateur naturalists. These family businesses were becoming established while the young men were in their teens and early twenties, and the example of working hard to build a business likely affected their attitudes toward naturalist work. Although they clearly enjoyed themselves, they strove for quality and chose to work under difficult conditions.

Finley was born in Santa Clara, California in 1876 and maintained close ties to California all his life. His parents, John Pettis Finley and Nancy Finley (née Rucker,) had come across the plains from Missouri as children in 1852 in the same prairie schooner train of five households including the Finleys, Ruckers, Lovells and Campbells, all of whom settled in Santa Clara County. ${ }^{5}$ According to Finley's Uncle Newton, who much

\footnotetext{
${ }^{4}$ Finley included detail about how he and Bohlman worked together in his many published pieces. See also Preston E. Anderson, "Ornithological Photography: An Appreciation of Two Earnest Workers," Camera Craft 14 (1907): 115-124; "Bird Studies and Pictures from Life with a Camera: William Lovell Finley, Herman T. Bohlman," The Craftsman 8 (1905): 613-622; Worth Mathewson, William L. Finley, Pioneer Wildlife Photographer (Corvallis, Or.: Oregon State University, 1986).

${ }^{5}$ Newton Gleaves Finley, 1922, Memories of Travel Across the Plains in 1852. Typewritten manuscript. BANC MSS C-D 5182, Bancroft Library, University of California, Berkeley.
} 
later wrote about the trip from memory, the Finley party included "Black Plim," as teamster, and "Black Sam," an assistant cook. ${ }^{6}$ The families brought livestock to sell in California in order to buy farm and ranchland, about 300 head of cattle, as well as 20 mules and some saddle horses. ${ }^{7}$ Finley's grandfather, James W. Finley purchased eighty acres for farming near San Jose. ${ }^{8}$

Finley's father, John Pettis Finley, began in a relatively humble position as a carpenter's apprentice at the age of sixteen, gaining skills he turned into a successful business in Portland. He built and sold caskets for the Pacific Manufacturing Company in California, and began travelling the West Coast as a company salesman. Later he settled in Portland to set up a Northwest branch of the company. He went into business for himself, first building caskets and then becoming an undertaker. In 1892, when William Finley was sixteen, his father established a mortuary and from 1902 until 1908 also served as Multnomah County Coroner. ${ }^{9}$ J.P. Finley and Son was an increasingly successful business in which both William Finley's brother Arthur and brother-in-law

\footnotetext{
${ }^{6}$ Newton is referring to Plim Jackson and Sampson Gleaves. William L. Finley's grandfather, James W. Finley, appears in the 1850 U.S. Census of Slaves Owners in Saline County, Missouri. Although slavery was legally prohibited in California due to the Compromise of 1850, in practice the status of blacks was less clear. Notes on the men's manumission papers on History San Jose website indicate James W. Finley identified the men as "slaves" in 1952 when Sheriff John Yontz took census. Plim Jackson and Sampson Gleaves were formally freed by James W. Finley in California with papers written in 1854 and filed in 1855 in Santa Clara County. See William Gleaves Family Bible, Gleaves Family Website, http://www.gleavesfamily.com/home/bibles/william_gleaves_bible.html; Asa Finley Will, text only, USGenweb.com http://files.usgwarchives.net/mo/saline/wills/fnlywill.txt; 1850 U.S. Census Slave Schedules, Saline County MO on Ancestry.com; Manumission Certificate: Sampson Gleaves, catalogue no. 1997-214-35, History San Jose, historysanjose.org; Manumission Certificate: Plim Jackson, catalogue no. 1997-297-1, History San Jose.

${ }^{7}$ Newton Gleaves Finley, Memories of Travel Across the Plains in 1852.

${ }^{8}$ Charles Henry Carey. 1922. History of Oregon (3 vols., Chicago: Portland, Ore: Pioneer Historical Publishing Co., 1922), 2: 384-385.

${ }^{9}$ Ibid.
} 
F.A. Kenny were employed. William Finley eventually was named a vice-president of the Finley mortuary and held stock, but does not seem to have been much involved in the family business. ${ }^{10}$

Bohlman was born in 1872 in Portland, Oregon, the son of German immigrants.

His father, Henry C. Bohlman, had trained as a sheet metal worker in Germany, and worked on waterworks projects in St. Petersburg, Russia. Arriving via New York about 1864, Henry Bohlman worked for an uncle in Sacramento, California, but soon moved to Portland through a connection with the Henry Weinhard family, in whose home he married Augusta Von Der Luhe on Christmas Day, 1867. Henry Bohlman worked as a tinsmith in Portland, and in the canning industry in Astoria and Alaska. He spent as much as six months of the year in Alaska, sometimes taking his oldest sons, Edward and Herman, with him. About 1894, with the help of Edward and Herman, he established a plumbing business on Portland. ${ }^{11}$

In 1896 at the age of twenty, Finley graduated from high school with honors in the Latin course. He gave the oration at the graduation ceremony. ${ }^{12}$ Between graduation and entry into University of California Berkeley in 1899 he focused on improving his chances for university admission and doing naturalist field work. Bohlman worked for

\footnotetext{
${ }^{10}$ Ibid. See also Mark, "Conflict and Compromise," 59; "Obituary: William L. Finley," Oregonian, June 30, 1953: 21. Regarding Arthur Finley and F.A. Kenny’s employment, see "Finley Drunk, Charge: Undertaker Arrested on Reckless Driving County: Motorman Says Young Man in Company With Woman Speeded Along Hawthorne Ave," Oregonian, February 22, 1920. 12:3; City Club of Portland (Portland, Or.), "The following applications...." City Club of Portland Bulletin 4 (April 11, 1924): 2.

${ }^{11}$ Joseph Gaston, Portland, Oregon, Its History and Builders: In Connection with the Antecedent Explorations, Discoveries, and Movements of the Pioneers that Selected the Site for the Great City of the Pacific (3 vols., Chicago: S.J. Clarke Publishing Company, 1911), 3: 254.

12 "Hail to the Class!" Oregonian (published as Morning Oregonian), June 20, 1896: 8.
} 
his father but was allowed some extended time away from work. In 1893 Bohlman took a month-long vacation devoted to "hunting and Ornithological work" observing and collecting waterfowl on Camas Prairie near Mt. Adams in Washington State. ${ }^{13}$ This was shortly before going to New York City for a three-month course to learn plumbing as a day student at the New York Trade School, while his brother Edward studied at the Pratt Institute. ${ }^{14}$ When the brothers returned, they used their skills to help their father begin his plumbing business, but Herman still spent a great deal of time in the field, especially after Finley graduated from high school. ${ }^{15}$

In the summer of 1897 Finley and Bohlman took their first extended field expedition. They traveled by canoe along seventy-five miles of the Willamette River, and then overland into the Cascade Range to the headwaters of the Santiam River, observing and taking notes. In the summer of 1898 they repeated the same trip and also spent time along the Columbia River.

It is unclear exactly when Finley and Bohlman began taking cameras along on their trips. Two very similar profiles of the young naturalists appeared in Craftsman magazine in 1905 and a 1907 issue of Camera Craft. These articles portray Finley and

\footnotetext{
${ }^{13}$ Herman T. Bohlman, "Collecting Among Aquatic Birds," Oregon Naturalist 4, (March-April 1897): 27. ${ }^{14}$ Herman Bohlman is listed as a member of the enrolling plumbing class of 1894 at the New York Trade School. At age 22, he would have enrolled in the last year of eligibility. See "New York Trade School," The Metal Worker, January 6 1894: 41; On typical plumbing courses for the period see Edward Combes, Report on Technical Education and Manual Training at the Paris Universal Exhibition of 1889, and in Great Britain, France, and the United States of America, New South Wales: G.S.Chapman, acting government printer, 1891: 228.

${ }^{15}$ Gaston, Portland, Oregon, Its History and Builders, 254.
} 
Bohlman as intense and serious students of the natural world, who spent their evenings on these early trips comparing and discussing notes by the campfire. ${ }^{16}$

Finley and Bohlman decided they would compete with John James Audubon to illustrate as many birds as possible. Their goal was to show the viewer the life of the bird, including its "home life, traits, and habits." They also hoped to create photographs with artistic merit. They recognized that a camera could capture and share aspects of bird behavior in ways that were not possible with stuffed bird skins organized in drawers. Whereas Audubon had generally worked in a studio with dead birds as models, they would capture images of birds behaving naturally in their usual habitats. They could also document the development of young birds over time, with much less sacrifice involved on the part of the birds. ${ }^{17}$ However, success with photography was not immediate.

During the summer of 1899, Finley and Bohlman spent time along the Columbia River, where they located the nest of a hawk they had noticed the previous year but could not figure out how to get up to it. ${ }^{18}$ They also took a trip up the Clackamas River. They climbed up cliffs along the river with their camera and heavy glass plates strapped to their backs, but while photographing bird nests on high rocks along the river, a strap broke, sending the camera and their plates down the bank to be smashed on the rocks below. ${ }^{19}$

\footnotetext{
${ }^{16}$ Anderson, "Ornithological Photography"; "Bird Studies and Pictures from Life."

${ }^{17}$ Ibid.

${ }^{18}$ William L. Finley, American Birds, Studied and Photographed from Life (New York: C. Scribner's Sons, 1907), 58.

${ }^{19}$ Anderson, "Ornithological Photography"; "Bird Studies and Pictures from Life."
} 
During the summer of 1900, Finley and Bohlman canoed down the Columbia River, taking photographs along the way, to the Lewis River. Their canoe overturned in some rapids on the Lewis, ruining their camera. They had thought to put some of their plates in waterproof bags tied to the canoe, and these were saved. ${ }^{20} \mathrm{~A}$ photograph of Finley on a river beach (Figure 1) is likely one of the salvaged plates. He is setting up a rough tent using tree branches as poles. Two oars are propped up on a large tree stump behind him.



Figure 1. Setting up camp on the Lewis River, n.d. Herman T. Bohlman Photograph Collection (P 202: camp), Oregon State University Special Collections and Archives Research Center, Corvallis, Oregon.

20 "Bird Studies and Pictures from Life." 
In the Finley and Bohlman partnership, Bohlman was the lead photographer, especially early on. In a brief 1901 article, his first for The Condor, the journal of the Cooper Ornithological Club, Finley describes Bohlman as the photographer and casts himself in the role of naturalist companion. ${ }^{21}$ Copyrights to photographs in the first few years were sometimes in Bohlman's name alone, and sometimes copyrighted to the two together. ${ }^{22}$ As late as 1908 , when writing about their experience photographing the California condors in the wild, Finley refers to Bohlman as the camera-man. ${ }^{23}$

By 1902 or thereabouts they regularly worked with more than one camera. Camera Craft reported in 1907 that Bohlman had partially built one of their early cameras to better suit their needs in the field, but didn't give details about what kinds of modifications he made. Camera Craft emphasized their equipment was not particularly elaborate. They generally used "a camera of the reflex type, made with an eye to lightness and bellows accommodation that permitted the use of an 8x10, series III Goerz lens, the camera taking a $5 \times 7$ plate. ${ }^{24}$ In his article for the San Francisco Call on photographing golden eagles in 1904, Finley had developed more technical expertise and detailed for the reader the advantages of various lenses: wide-angle for a view the nest in the foreground with the valley behind, single rear lens narrowing the field of the photo to the limb and nest, and telephoto. ${ }^{25}$

\footnotetext{
${ }^{21}$ William L. Finley, “Catching Birds with a Camera”. The Condor 3, no. 6 (1901): 137-39.

${ }^{22}$ However, Worth Mathewson, who spoke with Finley and Bohlman family members of Finley while researching his 1986 book William L. Finley, Pioneer Wildlife Photographer, was told it was Finley who first owned a camera. Personal communication with the author.

${ }^{23}$ William L. Finley, "Home Life of the California Condor," Century Illustrated Monthly Magazine 75 (Jan 1908): 370-380.

${ }^{24}$ Anderson, "Ornithological Photography," 124.

${ }^{25}$ William L. Finley, "The Golden Eagles of Mission Ridge," San Francisco Call, October 21, 1906.
} 
With Finley and Bohlman's earlier interest in collecting eggs and nests, it is not surprising they emphasized capturing the whole nesting cycle with the camera, photographing eggs in nests, parents incubating eggs, and then feeding the nestlings. They were then usually on the spot in hopes of getting good images of the young fledglings as they left the nest. Because the photographers had been watching and photographing them for several weeks, the young birds were often habituated to their presence and the cameras. The chicks would also tire of flying quickly and were then relatively cooperative when lined up with their siblings for a photo. The line up was a favorite shot. Finley and Bohlman used it with a variety of birds including chickadees (Figure 2), kingfishers, and owls. ${ }^{26}$



Figure 2. Chickadees, n.d., William L. Finley Papers (MSS Finley), Oregon State University Special Collections and Archives Research Center, Corvallis, Oregon.

${ }^{26}$ Other bird photographers active at the time such as Chester A. Reed, an ornithologist and artist in Massachusetts, C. William Beebe, an ornithologist best known today for his experimental work with the Bathysphere, and Irish-born, New York-based Arthur Radclyffe Dugmore, artist, author, and adventurer, all used a similar line-up composition. 
In addition to their field expeditions, Finley and Bohlman took photographs of ordinary birds around Portland. As Finley noted, at that time there were not many photographs of common birds so one did not have to venture far for appropriate subjects. ${ }^{27}$ They took pictures of bushtits, scrub jays, chickadees, crows, wrens and robins. ${ }^{28}$ Photography as practiced by the Finley-Bohlman team owed much of its success to patience, persistence, and occasional daring. A series of photographs of a rufous hummingbird on its nest (Figure 3), and later raising its young, came after three years of paying close attention to the hummingbird nesting sites and behavior. ${ }^{29}$

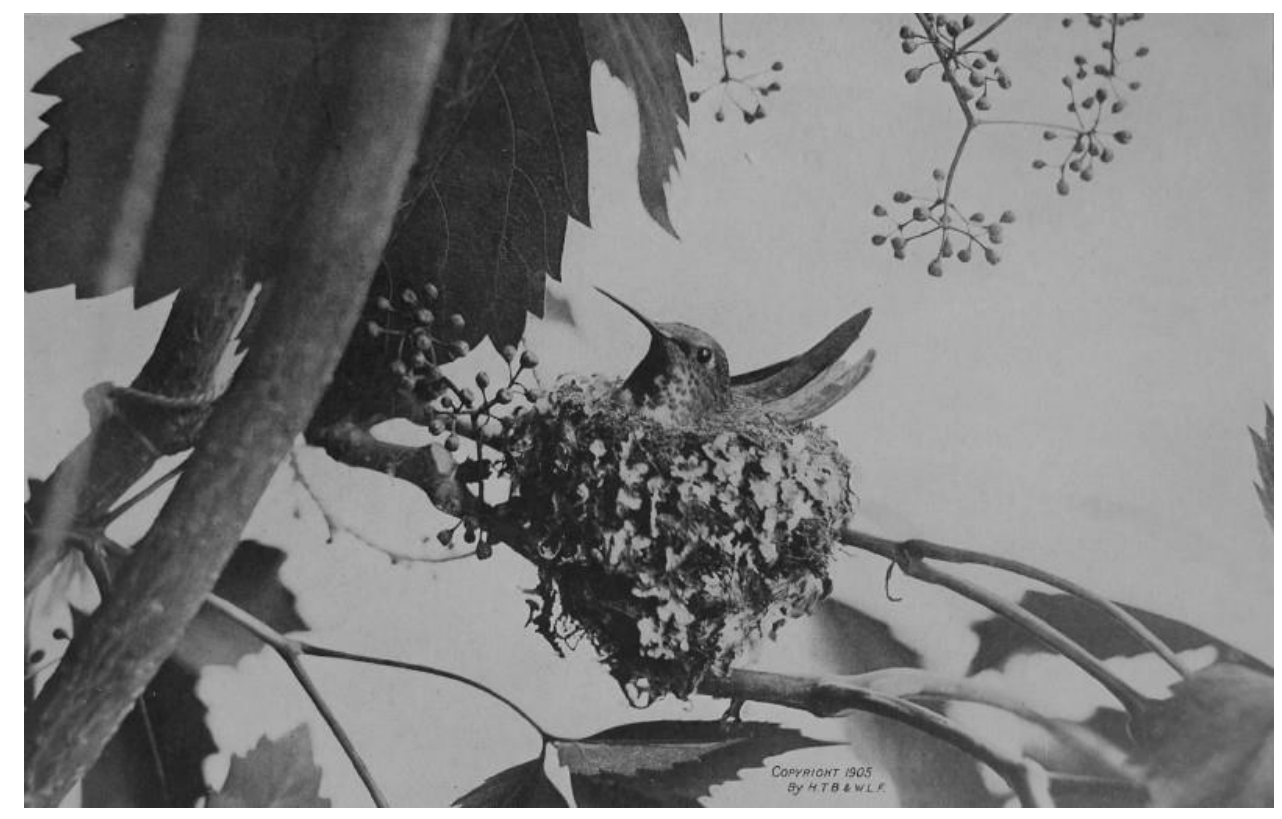

Figure 3."Rufous at home.” From William L. Finley, American Birds (1907) opposite page 8. www.kellscraft.com

\footnotetext{
${ }^{27}$ William L. Finley, "Catching Birds with a Camera."

${ }^{28}$ Finley referred to scrub jays as blue jays.

${ }^{29}$ William L. Finley, American Birds, 3.
} 
Finley and Bohlman spent months watching a pair of belted kingfishers that nested near a place called Ladd's Pond in southeast Portland to get their 1901 kingfisher photographs ${ }^{30}$ Noticing a male kingfisher with a deformed bill, Finley and Bohlman tracked him back to his nest in a bank about half a mile from the pond, dug carefully into the bank to confirm the nest was there, and took some photographs. After re-covering the nest, they kept it under close watch until the nesting pair were both fishing at the same time - a sign the eggs had hatched. When the chicks emerged, Finley and Bohlman were ready.



Figure 4."Six of the frowzy-headed Fishers in a pose." From William L. Finley, American Birds (1907) opposite page 145. www.kellscraft.com

The kingfisher photographs appeared in Finley's 1907 book American Birds. In the first photograph (Figure 4) six young kingfishers perch in a line along a sturdy

\footnotetext{
${ }^{30}$ William S. Ladd had farms in the neighborhoods of Laurelhurst, Eastmoreland and Westmoreland, but this Ladd's Pond is probably today's Laurelhurst Lake in Laurelhurst Park.
} 
branch. It required a whole day for the photographers to set up and get the shot. ${ }^{31}$ The second, (Figure 5). shows the kingfisher fledgings on their first day out of the nest.

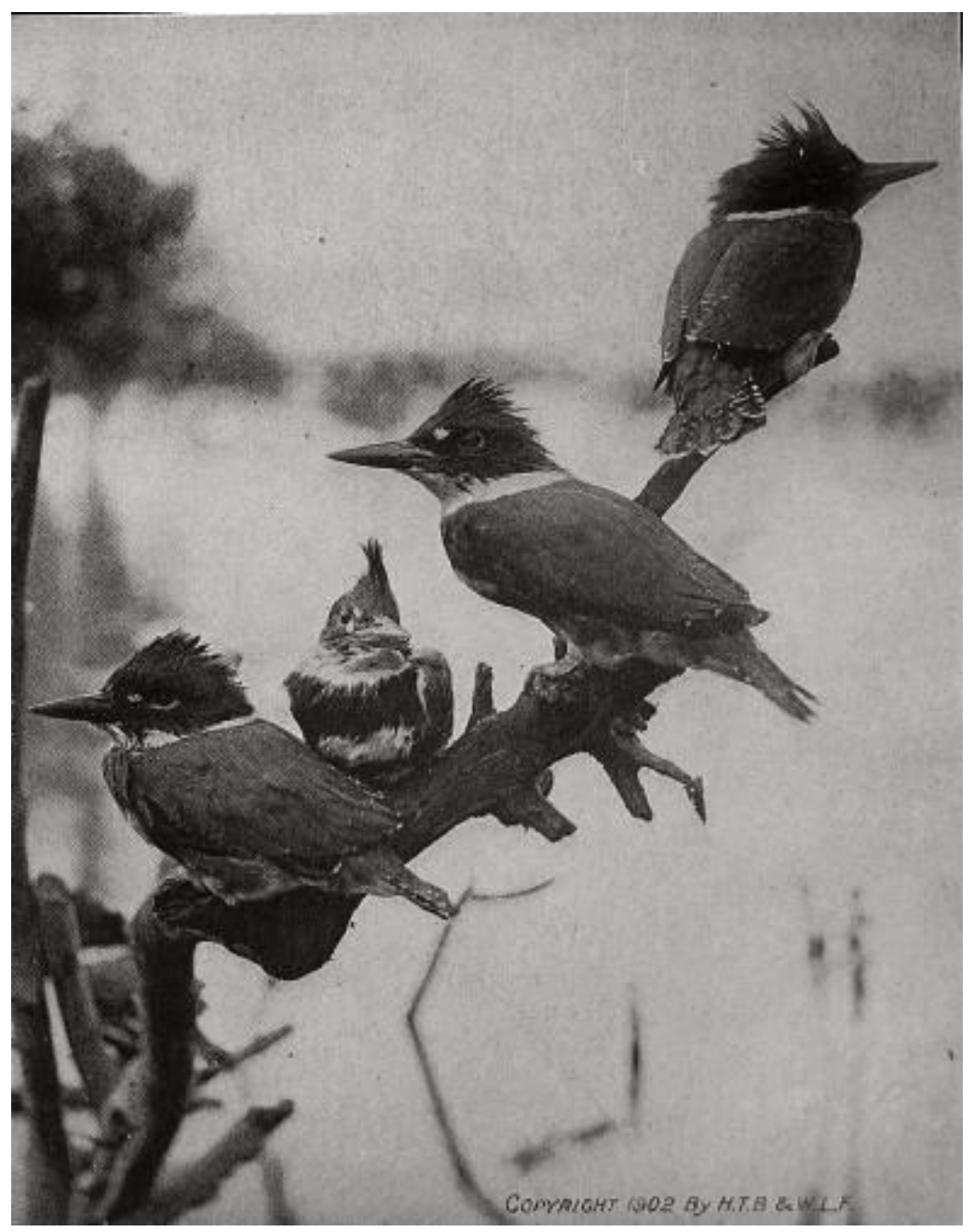

Figure 5. "The first day out of the nest fully fledged." From William L. Finley, American Birds (1907), opposite page 140. www.kellscraft.com

${ }^{31}$ William L. Finley, American Birds, 139-147. 


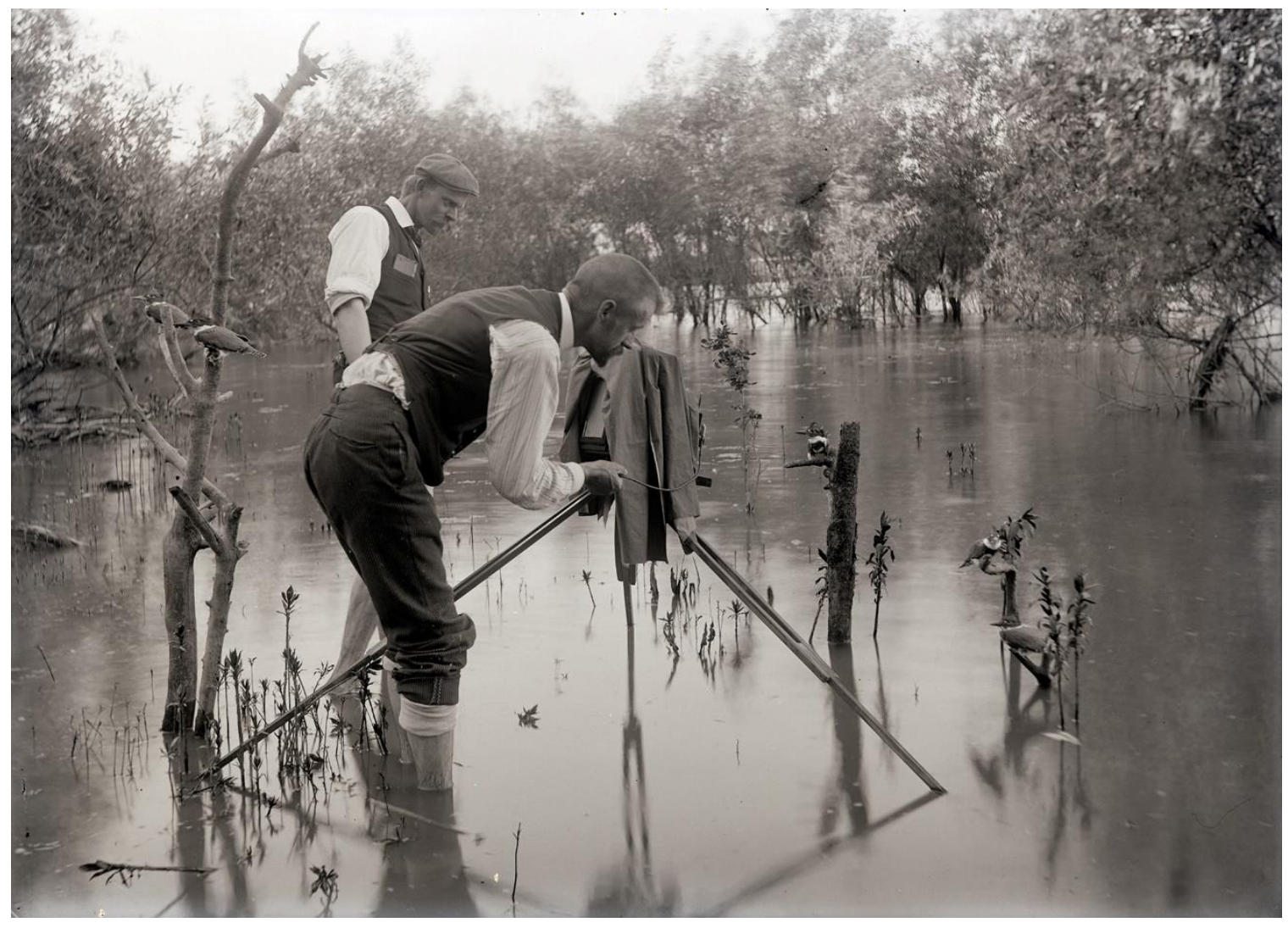

Figure 6. Photographing kingfishers. A.W.Anthony (front) and Herman Bohlman photographing kingfishers ca. 1901, Finley A2723, William L. Finley Photographs Collection, circa 1900-1940 (Org Lot 369) Oregon Historical Society, Portland, Oregon (hereafter OHS).

In a third photograph (Figure 6) Bohlman and friend and fellow naturalist A.W.

Anthony (front) photograph a young kingfisher. ${ }^{32}$ Finley may be taking the photograph

of the photographers; it is a good example of how he and Bohlman liked to capture not

32 Anthony had been a member of the Northwest Ornithological Association and in 1904 served as president of the Oregon Audubon Society chapter. He would go on to a notable career as a collector and naturalist, travelling to Alaska, Mexico and Guatemala. He discovered several new species and served as Director of the San Diego Natural History Museum. He also worked as a miner and as a rancher in Eastern Oregon. 
only birds on camera, but also their own interactions with them. Bohlman and Finley documented themselves at work, climbing trees or cliffs, wading, using different modes of transportation, and camping. There are photographs in which they carry cameras, tripods, and bags of plates. Bohlman enjoyed a technical challenge and appreciated the humor of appearing in his own photographs. He often set up the shots, and pulled the shutter with an attached string (Figure 7).

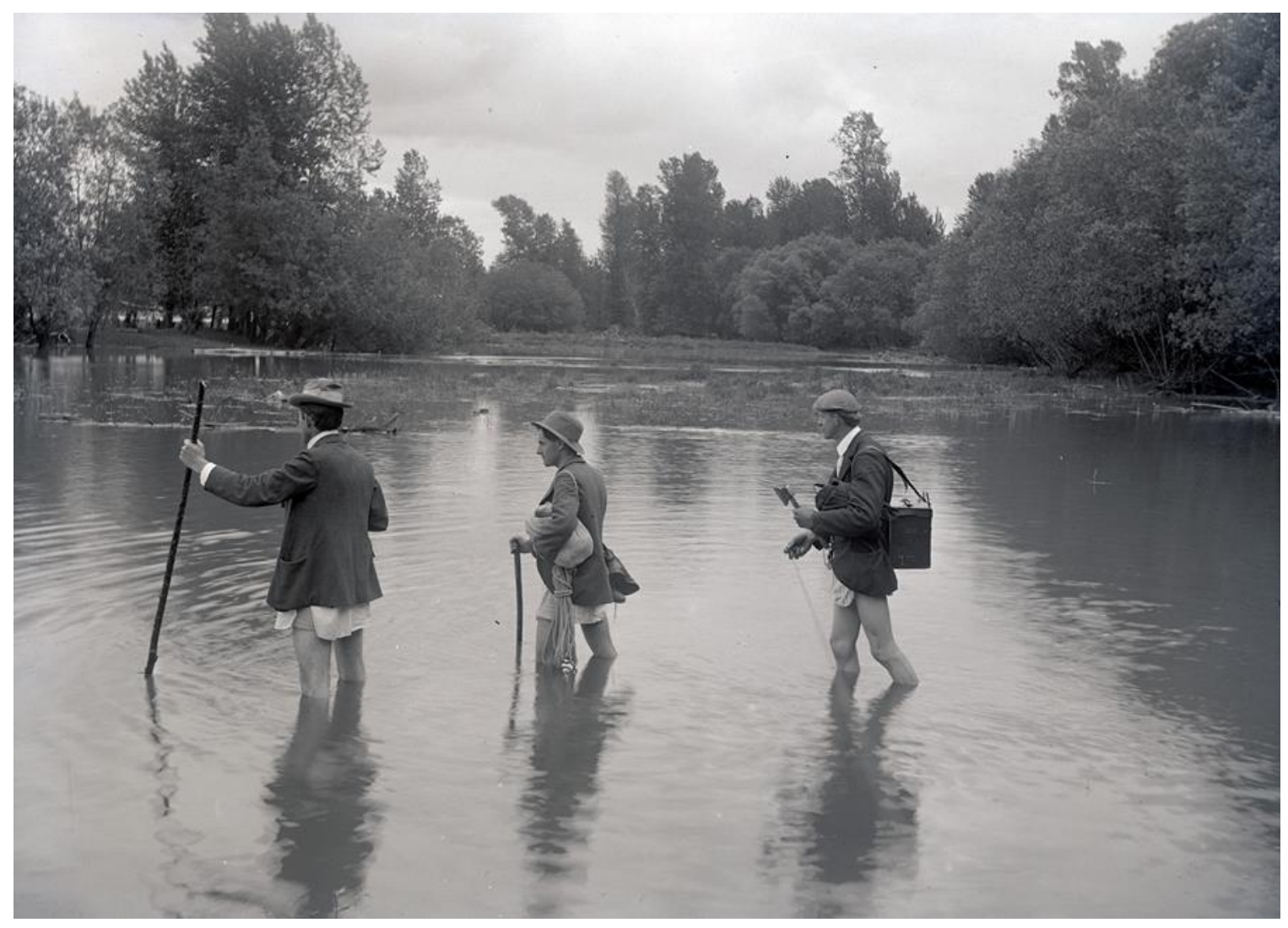

Figure 7. Wading to the hawks' nest. William Finley (center), Herman Bohlman (right) and their friend Ellis F. Hadley of Dayton, Oregon, near the Columbia River ca.1901. Finley has rope which they used to pull down saplings to create a bridge up the taller nesting tree. Bohlman has a camera case over his shoulder, holds an ax in his left hand while his right hand is pulling a string attached to a camera shutter. Finley A2652, William L. Finley Photographs Collection, OHS. 
When Finley submitted articles to magazines he usually selected photographs that included himself and Bohlman in addition to photos of birds. He recognized the promotional value of images of the photographers at work in the treetops or burdened with gear. He wrote affectionately about his laconic partner and created an appealing image of the two as a team by combining his descriptions of their expeditions with the photographs. In addition, the photographs show the men engaging with wildlife. Wild birds are not presented as part of a separate natural world — the title of Finley's 1928 book Wild Animal Pets is foreshadowed by images of Finley and Bohlman handling birds.

Finley often used the expression "camera hunting" in the titles of his published pieces, a popular contemporary term coined by George Bird Grinnell in Forest and Stream in 1892 . Early practitioners desired photographs as trophies demonstrating sportsmanship and hunting prowess. It was more difficult to get a good photograph than to kill an animal but many camera hunters used traditional hunting techniques, such as blinds, treeing animals with dogs or jacklighting — shining a light at night to cause an animal to freeze. The trophy photograph stemmed from a display tradition reflecting man's mastery over animals. George Bird Grinnell's friend Theodore Roosevelt was a strong proponent of camera hunting, claiming the sport allowed the development of virility necessary for continuing success of the nation. ${ }^{33}$

\footnotetext{
${ }^{33}$ Matthew Brower, Developing Animals: Wildlife and Early American Photography (Minneapolis: University of Minnesota Press, 2010), 25-82. Brower notes Theodore Roosevelt himself continued to hunt in the usual way. Grinnell's argument that camera hunting was a superior demonstration of sportsmanship, making the act of killing the animal unnecessary, was not understood by all Forest and Stream readers. For instance, in 1892 in Forest and Stream a Pennsylvania man writing as "Pigarth" describes a camera gun he
} 
The images of Finley and Bohlman do not present an image of triumphant masculinity. They frequently look faintly ridiculous, and intentionally so, sitting in herons' nests, posing with baby birds perched on their heads or wading through water with no pants. Finley's articles often dwelt in a humorous way on the difficulties and discomforts they encountered, and the images they published showed themselves meeting physical challenges in nature, so one can imagine the appeal for Theodore Roosevelt, an ornithologist himself.



Figure 8. With flickers. William L. Finley (above) and Herman T. Bohlman (below). Finley A2597, William L. Finley Photographs Collection, OHS.

invented to capture the image of when a bird in flight is hit by his bullet. Pigarth admitted "you don't get very good 'pictures' by this method, but you will get some very queer photographs." Pigarth, "A Gun Camera," Forest and Stream, 39 (August 1892): 92. 
A photograph of Finley and Bohlman with flickers on a dead tree (Figure 8), demonstrates many of the best elements of the men's photography. Energy and humor are apparent in the composition of the photograph, which also features clarity of the images of the birds and conveys information about how flickers live. Flickers are handsome birds, and, although the photograph does not show the black crescent bib because of the angle of the birds in relation to the camera, other details of the plumage and the shape of the beak are clear. Finley is higher in the frame, while Bohlman's head and shoulders are in the lower left-hand corner of the photograph. Bohlman, with a fledgling perched on his hat, is probably taking the photograph. Finley has a bird on his shoulder and another on an arm.

In American Birds, Finley writes when the men had noticed the birds using the nesting tree, they climbed a neighboring tree to get a better view to identify the exact location of the nest. To get up to the nest, once they found it, they used a twenty-five foot ladder. Getting a good photograph of the large clutch of eggs required sawing a temporary window into the tree opposite the birds' entrance to let in some light. This was "diplomatically" done, and the missing piece replaced when the exposures were made, and although the mother bird flew away during the activity, she later returned and was apparently none the wiser. ${ }^{34}$ There was not enough room to focus the camera at the top of the tree, so they attached it to a board about four feet long, "ready to snap" and carried it

\footnotetext{
${ }^{34}$ Gertrude Metcalfe, "Birds of the Northwest: the Nesting Season," Pacific Monthly, 7-9, (April 1903):
} 221-222. 
that way up the ladder (Figure 9). ${ }^{35}$ A mirror was also used to reflect more light into the hole. ${ }^{36}$ According to Finley, they nearly dropped the camera on the first attempt, and the process had to be repeated a few times before they managed to get a good photograph. ${ }^{37}$

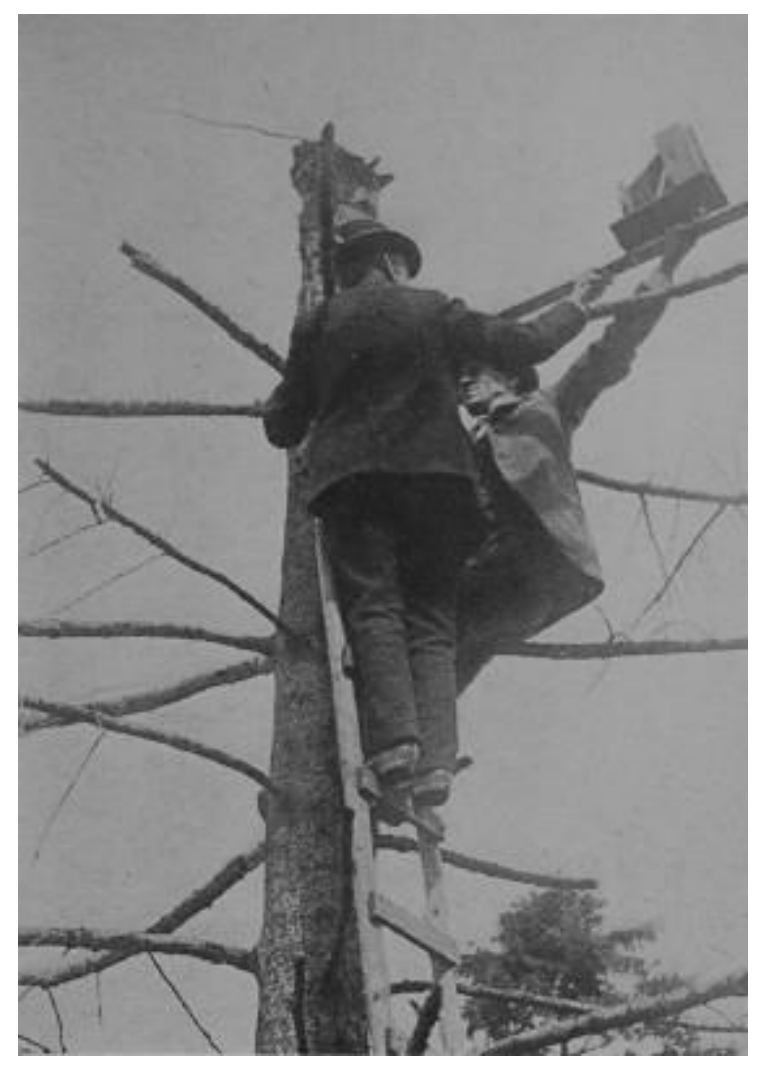

Figure 9. "Photographing the Flickers' nest." From William L. Finley, American Birds, opposite page 28. www.kellscraft.com

Although the selection and layout of photographs in American Birds implies Finley and Bohlman took their close-up shot with the flickers while perched themselves at the top of the tree, another photograph (Figure 10) reveals how the shot was done.

\footnotetext{
${ }^{35}$ Finley, American Birds, 28.

${ }^{36}$ Metcalfe, "Birds of the Northwest."

${ }^{37}$ Finley, American Birds, 29.
} 


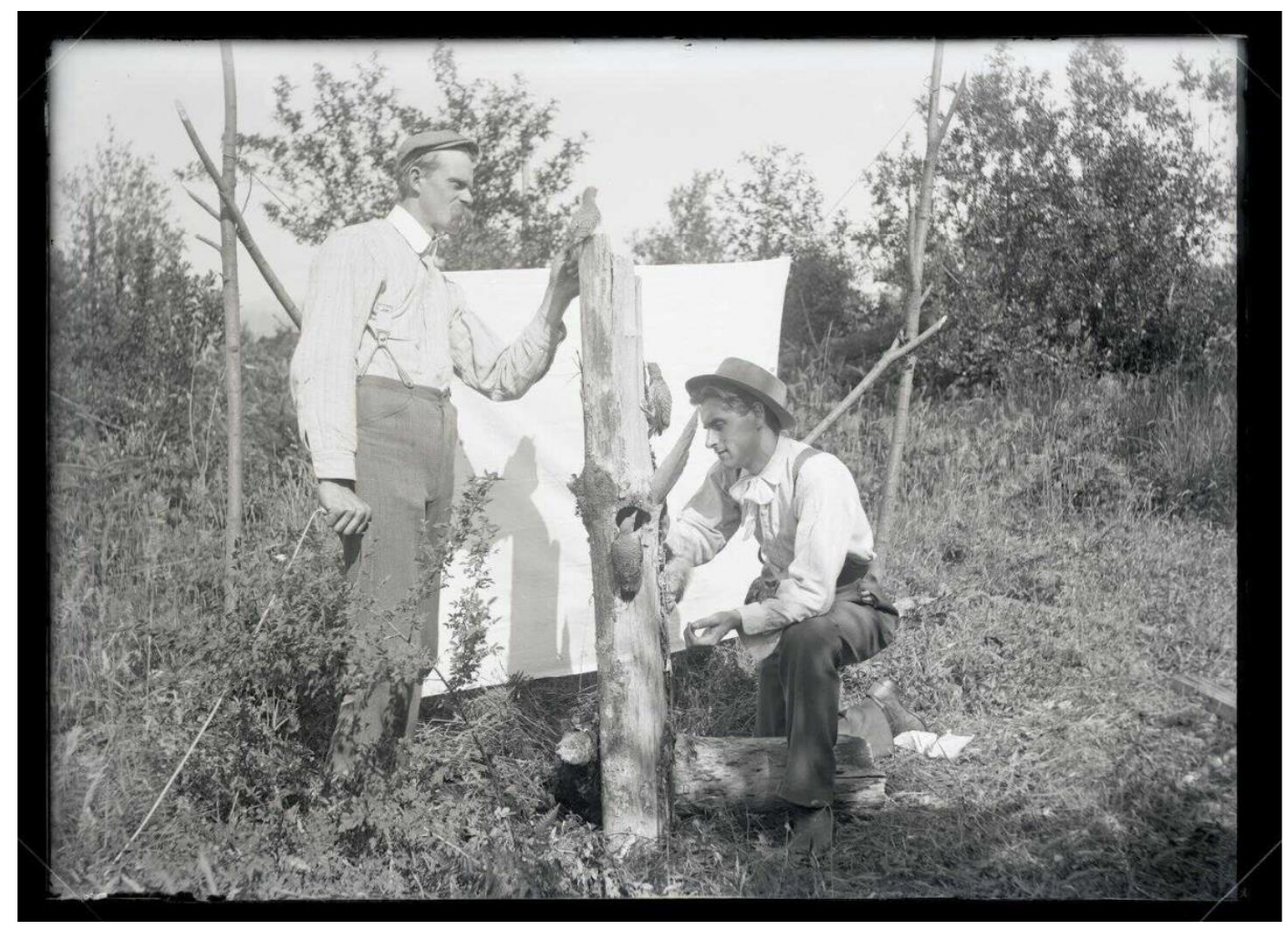

Figure 10. Setting up the shot. Herman T. Bohlman and William L. Finley photographing flickers in Fulton Canyon, Sherman County, Oregon, 1902. FinleyA2595, William L. Finley Photographs Collection, ca.1900-1940, OHS.

Another project requiring planning and ingenuity was a series of red-tailed hawk photographs begun in 1898 and finished about 1902. After several years planning, Finley and Bohlman were able to photograph a red-tailed hawk's nest, and later two young hawks. Red-tailed hawks often mate for life and a pair will use a good nest for years. On a summer hunting trip in 1898 along the Columbia River a local farmer pointed out to Finley and Bohlman an old hawk that always nested nearby. ${ }^{38}$ They returned to the area in the spring of 1899 , and watched a hawk pair engaged in aerial mating displays, soaring

\footnotetext{
${ }^{38} \mathrm{Ibid}, 57$.
} 
together in circles high in the air. ${ }^{39}$ They successfully located the hawks' nest in one of the tallest trees, but, Finley wrote, "one look sufficed to give us both the same opinion: the nest was beyond human reach." ${ }^{\prime 4}$ Finley and Bohlman estimated the nest to be about one hundred and twenty feet up in a cottonwood tree with no low branches that could be used for ropes to aid in climbing up.

According to Finley, "We schemed for three different summers...before we succeeded in levelling our camera at the eggs." ${ }^{41}$ In 1900, Bohlman found a way for them to reach the nest. ${ }^{42}$ First, the men chopped a much smaller cottonwood tree standing near the hawks' nesting tree, most of the way through. Then they used ropes to pull it in the direction they wanted, so that it fell over onto the nesting tree. The smaller tree wedged into the lowest branches of the larger tree, forty feet above the ground, and its angled trunk served as a bridge the men could climb into the taller tree's branches. From there, the two used ropes and climbing-irons to climb the remaining eighty feet to the nest. The camera they were using was large, and one of the challenges in producing clear photographs with timed exposures was keeping the camera steady, not easy to do when perched on a tree branch one hundred and twenty feet off the ground. In this case, they were fortunate. Just above the nest was another spot where branches would support the weight of the camera and photographer. All they had to do was haul everything up.

\footnotetext{
${ }^{39}$ Mathewson, 24.

${ }^{40}$ Finley, American Birds, 57.

${ }^{41}$ Ibid, 58.

${ }^{42}$ Mathewson, 24.
} 
Finley included three photographs in American Birds to document how he and Bohlman got up to the nest. In the first (Figure 10), Bohlman demonstrates their "bridge" by climbing the angled trunk of the smaller tree. Next, he and the camera are strapped to either side of a thick tree branch with the camera angled down towards the nest (Figure 11). The third photograph (Figure 12) shows Bohlman climbing up toward the nest. They needed rope and climbing irons to bridge gaps of eight to 10 feet between branches on their way up.

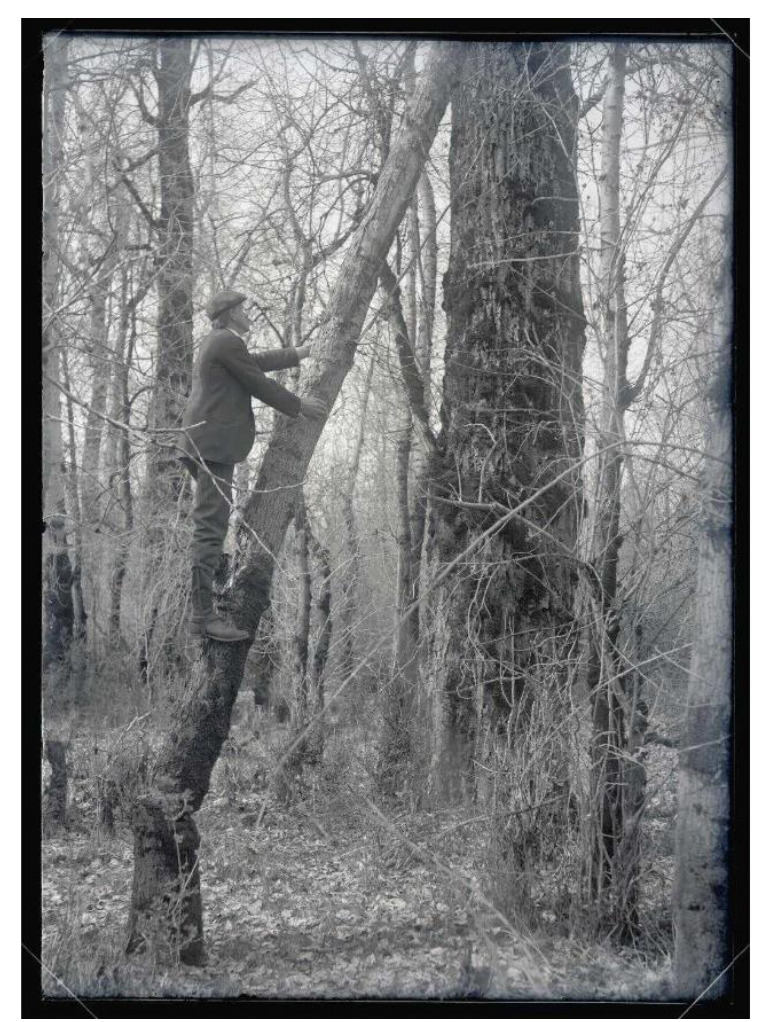

Figure 11. Bohlman climbs the "bridge" tree that leans against the red-tailed Hawks' nesting tree. Finley A2558, William L. Finley Photographs Collection, OHS. 


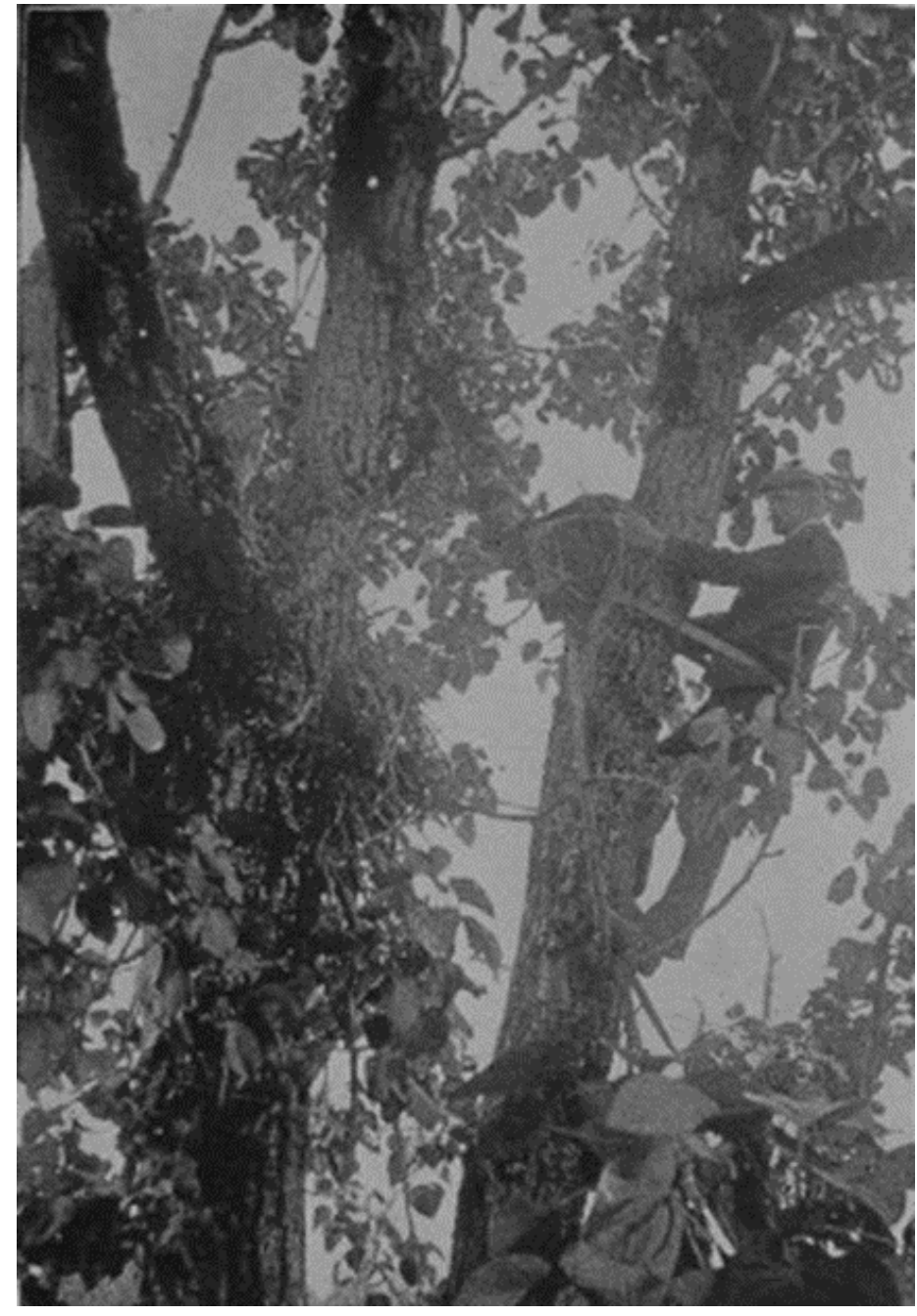

Figure 12. Bohlman with camera strapped to tree trunk. William L. Finley, American Birds, opposite page 58. www.kellscraft.com 




Figure 13. Bohlman climbing to red-tailed hawks' nest. Finley A2654, William L. Finley Photographs Collection, OHS.

In April of 1900 or 1901, Finley and Bohlman photographed two eggs in the nest. They returned in early May to take photographs of the young chicks. Towards the end of May they returned and photographed the young hawks standing on the edge of their nest, ready for flight (Figure 14). By June, Finley, Bohlman, and their friend Ellis Hadley had to wade to reach the tree, because of the natural seasonal river rise (Figure 7). They also scouted areas around the nest, and one morning observed the male red-tail struggling to carry a large fish. When they arrived at the nest that afternoon with their cameras they 
found the fish remains there and managed to get a shot of one of the young red tails in the nest with a carp's tail at its feet. On another visit they discovered seven catfish heads. ${ }^{43}$

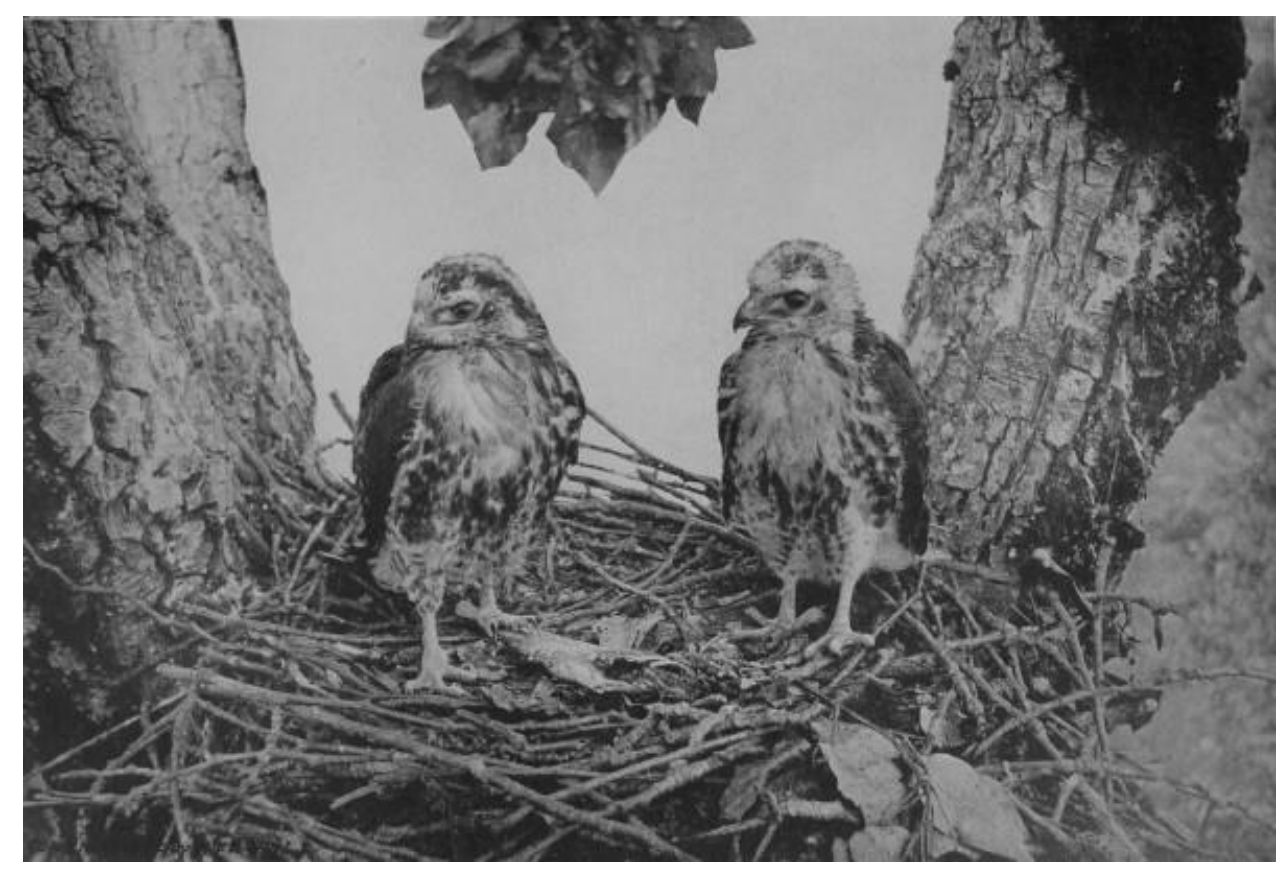

Figure 14. Young hawks standing on the edge of the nest. William L. Finley, American Birds, opposite page 64. www.kellscraft.com

In June 1901, after they finished photographing the young hawks, Finley, Bohlman, and their friends Ellis Hadley and Ross Nicholas went to the Oregon coast for a collecting trip, setting out from Hadley's farm in Dayton (Figure 15) ${ }^{44}$ Finley and Bohlman also wanted to take cameras out to Three Arch Rocks off the beach at Oceanside, which hosted a variety of seabird colonies. According to Mathewson,

\footnotetext{
${ }^{43}$ Finley, American Birds, 57-63; William L. Finley, "Photographing the Aerie of a Western Red-Tail," The Condor 7, no. 1 (Jan-Feb 1905): 3-7.

${ }^{44}$ Ellis Hadley and Ross Nicholas had also been members of the Northwest Ornithological Association, discussed in chapter two of this thesis.
} 
Nicholas was to be chief scientific collector, Bohlman cook and primary photographer, and Hadley would drive. Finley was to assist with both cooking and photography, and keep a written record of their trip for posterity. They brought a bicycle for scouting, and a dog to protect camp. ${ }^{45}$

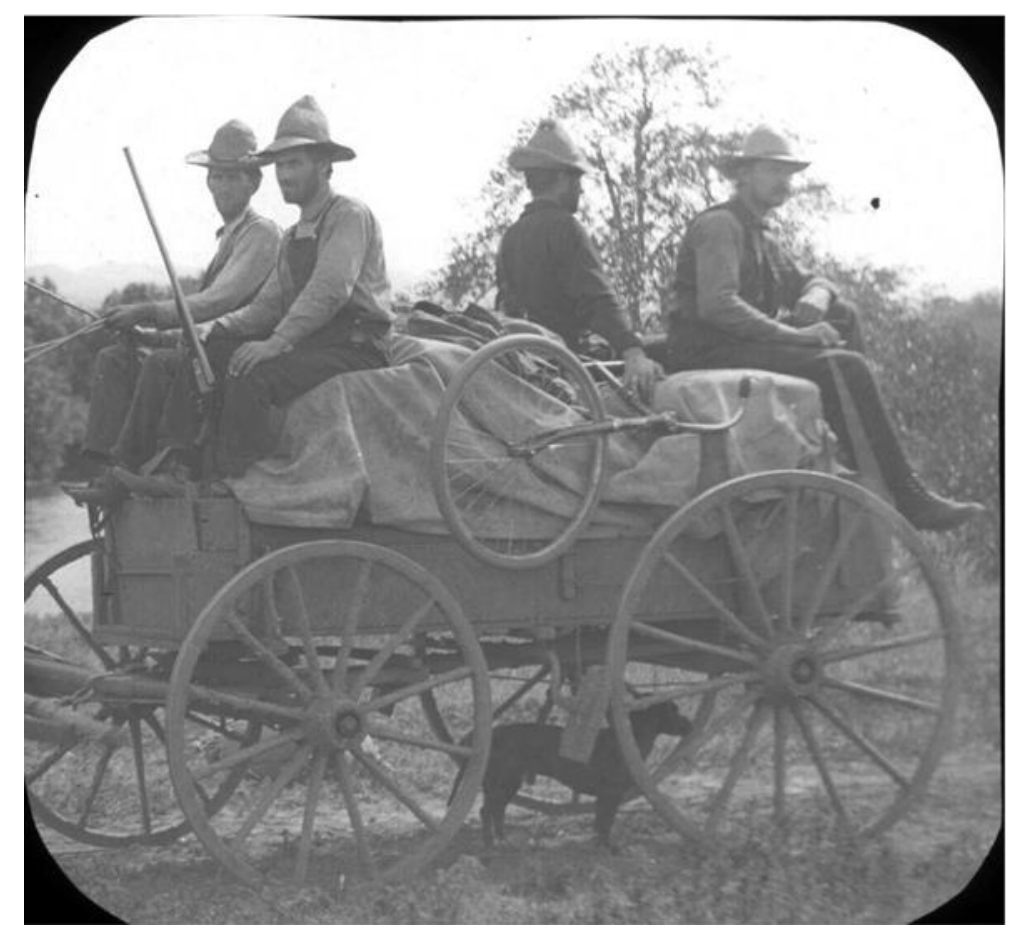

Figure 15. Heading to the Oregon coast. Ross Nicholas, Ellis Hadley, William Finley and Herman Bohlman, 1901. Herman T. Bohlman Photograph Collection (P 202; wagon), Oregon State University Special Collections and Archives Research Center, Corvallis, Oregon.

They camped for a night in the Tillamook area. In the morning they found the road to the beach too difficult for their horses with their heavy wagon. Fortunately, they were able to hire a teamster with a team of four horses to pull them through to Netarts

${ }^{45}$ Mathewson, 33-34. 
Bay. Finley and Bohlman hiked over to Oceanside, where there was a Tillamook fishing camp, and hired a sea lion hunter to take them out to the rocks in his boat. In The Condor, Finley reported the weather was not good; they were only able to make two short trips out. $^{46}$

In terms of photography, the trip was not especially successful. Bohlman's photographs that accompany Finley's Condor article lacked the contrast and clarity of later work on the rocks. Finley wrote "Our time was too short...At every turn scenes of bird life that would have made interesting pictures presented themselves, but the difficulties in the way of success were almost as numerous." A photograph of murres is notable because of the density of birds, and they did manage to photograph a puffin on her nest by carefully uncovering her burrow (Figure 16). ${ }^{47}$

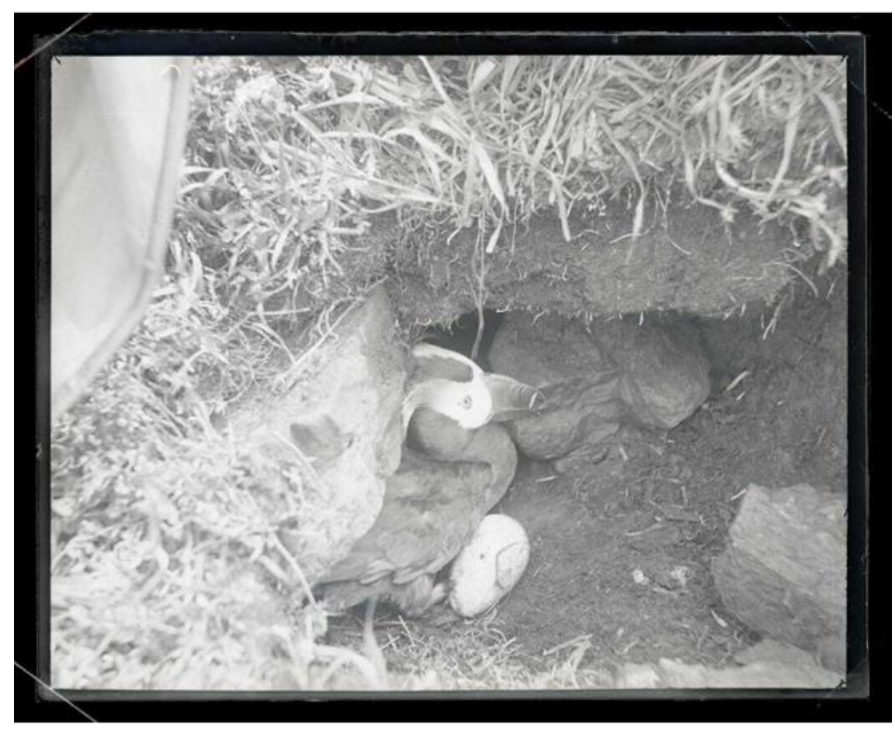

Figure 16. Puffin in burrow. Finley A2526, William L. Finley Photographs Collection, OHS.

\footnotetext{
${ }^{46}$ William L. Finley, "Among the Sea Birds of the Oregon Coast." The Condor 4, no. 3 (1902): 53-57.

${ }^{47}$ Ibid, 55.
} 
The challenges they experienced on their first trip to Three Arch Rocks inspired them to plot ways to achieve a more productive trip. Finley and Bohlman returned in 1903 planning to camp out on a rock ledge on one of the Three Arch Rocks in order to have more time to take photographs. They had prepared camping equipment: waterproof tenting, wood—-both for fuel and planks to create level surfaces—-hand tools such as drills and axes, food, and drinking water. Finley reported they also took a couple of $5 \times 7$ long focus cameras and 150 heavy glass plates. They were not able this time to find anyone willing to row them out to the rocks, but they did get a small dory boat at Netarts. Launching from the beach was difficult, especially with the boat overloaded with their gear. They decided they would have to make two trips, throwing their things out onto the rocks, and then haul the boat up onto a ledge. They needed a relatively calm day. ${ }^{48}$

It was the end of June and raining. They waited, camped on the wet beach for sixteen days, and then tried four days in a row to get the boat beyond the breaker waves before successfully reaching calmer water beyond the surf. They chose the rock furthest out as the one that looked most "campable" as Finley put it, comparing the situation to "hunting for lodging on a winding stair-case." 49 They wedged boards onto rough ledges, to give themselves a place to sit, cook, and sleep (Figure 17). They spent five days on the rock, sleeping on wet weeds and climbing around using ropes to take pictures by day (Figure 18).

${ }^{48}$ William L. Finley, "An Adventure in Modern Photography," The Pacific Monthly 13 (January 1905): 1623; William L. Finley, "Among the Sea Birds off the Oregon Coast, Part I" The Condor 7, no. 5 (1905): $119-27$.

${ }^{49}$ William L. Finley, "Among the Sea Birds off the Oregon Coast, Part I," 122. 


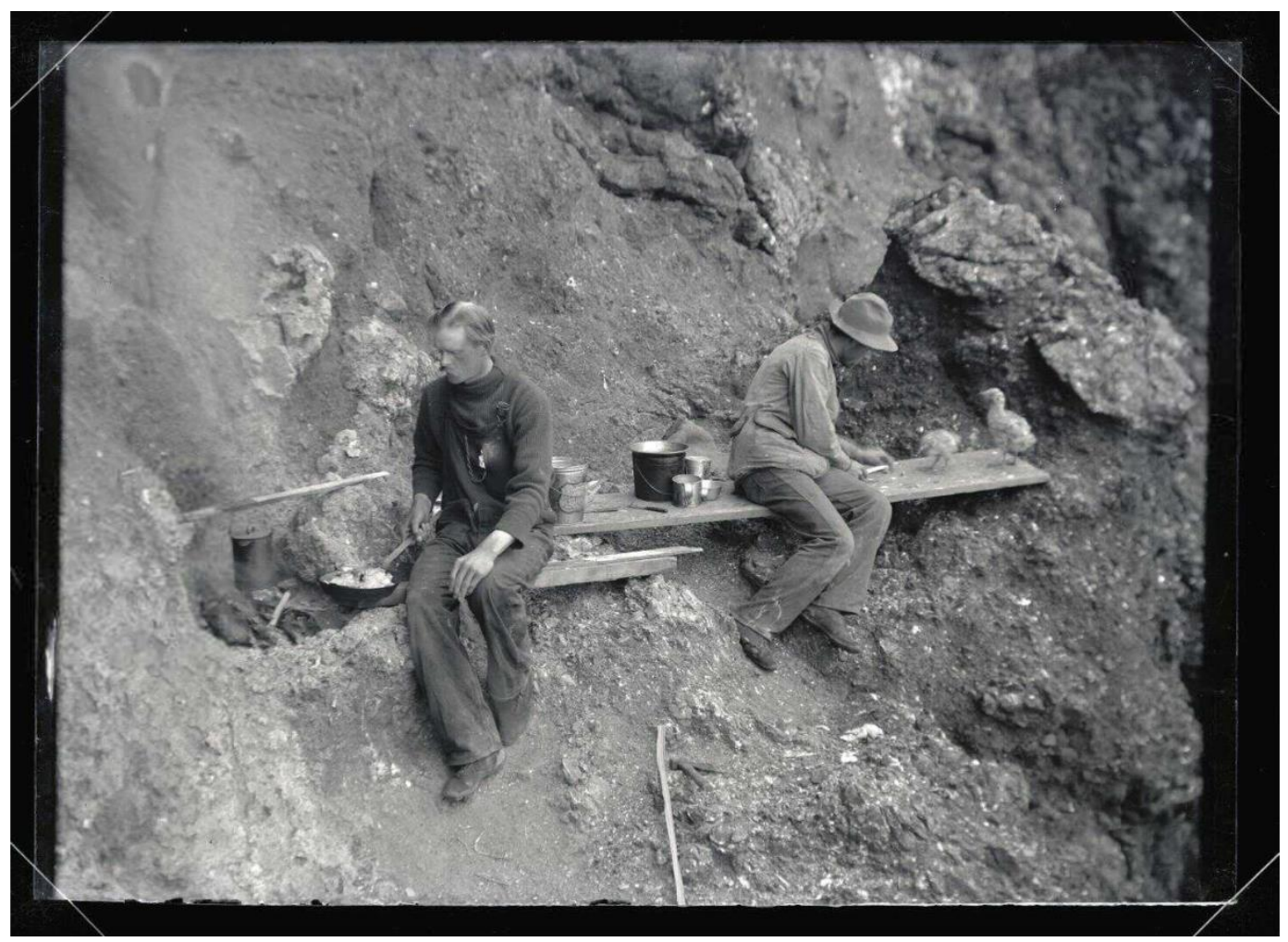

Figure 17. Camped on Three Arch Rocks. Finley is feeding young gulls, while Bohlman cooks and takes the photograph. Finley A2519, William L. Finley Photographs Collection, OHS.

Filled with murres, cormorants, and gulls, each in their own territories on the rock, the noise was "ear-splitting" and the rock stank. They had to watch out for both rubble and baby birds falling from above them. They discovered storm petrels nesting in burrows at the rock's summit, and learned that a petrel dragged from its burrow will spit fish oil at the aggressor. They ruined their shoes. It was an adventure and the photographs they obtained helped convinced Theodore Roosevelt to designate Three Arch Rocks as the first wildlife refuge in the American West. 


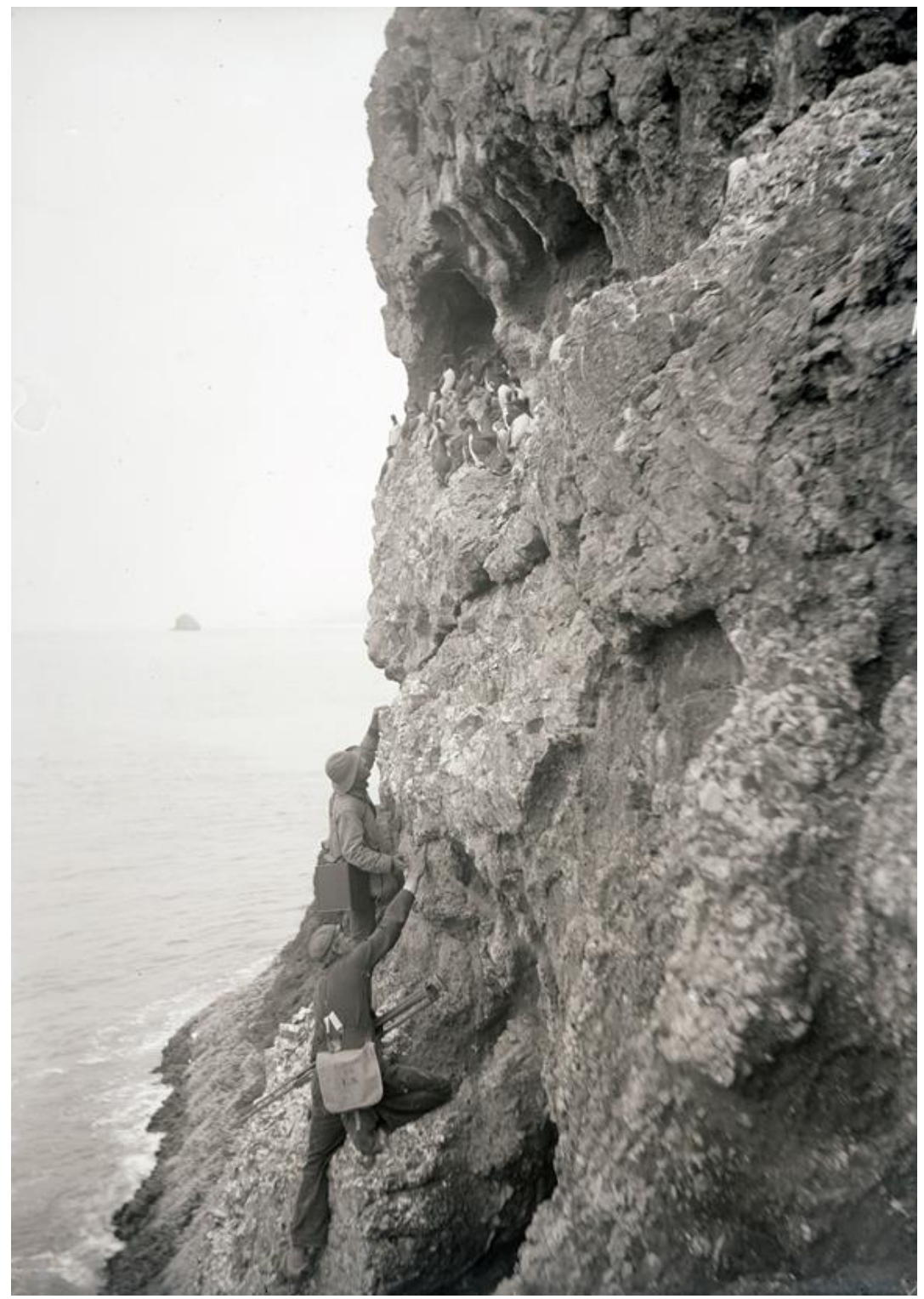

Figure 18. Reaching the murres. Finley and Bohlman climbing up to photograph Murres at Three Arch Rocks in 1903. The string Bohlman used to pull the shutter is faintly visible from his right hand. Finley A2652, William L. Finley Photographs Collection, OHS.

Through his early field and photography work with Herman Bohlman, Finley established himself as an expert among other ornithologists, in spite of his youth and lack 
of a university degree in the sciences. He developed a stock of material with which to launch a career as a popular naturalist, in the process encouraging the public to value birds and other wildlife they encountered. This material served as his entrée into a larger circle of scientists, wildlife managers and exceptional amateurs like himself. His people skills — the ability to recognize talent, collaborate, inspire, and organize — were also essential to his success. These were sharpened though his involvement in several key organizations: the Northwest Ornithological Association, the Cooper Ornithological Club, and the National Societies of Audubon. 


\section{Chapter Two}

Flocking Together: Finley and Ornithology Organizations 1894-1910

An important aspect of William L. Finley's role as a conservationist was his ability to reach a variety of audiences. He had a flair for networking, a knack for collaboration, and was quick to see the potential in various forms of media for influencing public opinion. He became a successful "expert-amateur" in an era of increasing professionalism through a combination of self-education, production of high quality work, and association with professionals and people in influential positions. As a result, he served as a link between urban and rural dwellers, scientists, sportsmen, and wildlife managers, and even the East and West Coasts.

Finley recognized the importance of garnering attention and support of the East Coast-based conservationists to secure protection for wildlife in the West. His photography partnership with Herman Bohlman was foundational to his success, especially as the photographs, and the articles and reports Finley wrote about his work in the field as a naturalist, were his credentials in the absence of formal training. However, also key to Finley's success was his involvement in ornithological clubs and associations, such as the early Northwest Ornithological Association, the Cooper Ornithological Club in California, and Audubon. He learned from people he met in these groups, many of whom had formal education in science, and reached a wider audience through the connections he made. 
The Northwest Ornithological Association (NOA) was an association of collectors with scientific ambitions operating from 1894 to 1897 in Oregon. Teenage boys were the primary collectors of eggs and bird skins, and made up much of the membership of this small group. There were a few members who were not amateurs, however, and the NOA gained enough recognition to be included when the city began providing space for some Portland science associations. The Cooper Club, established in San Jose, California in 1893, grew under the leadership of Joseph Grinnell into a sciencefocused organization closely associated with the American Ornithologists Union. The National Audubon Society emerged from a collection of state level organizations which joined together in 1901 as the National Societies of Audubon, with bird protection and advocacy as primary aims. Finley gained experience both as a naturalist and in leadership through his participation in the NOA, the Cooper Club gave him access and credibility within a group of professional ornithologists, and through Audubon he developed skills in organizing and activism.

Northwest Ornithological Association (1894-1897)

On December 28, 1894 Finley, then eighteen years old and still a high school student, and eleven other young men, including Finley’s friend Herman Bohlman, attended the founding meeting of the Northwest Ornithological Association, the purpose of which was to promote serious amateur study of birds. Its first meeting took place at Finley's home, but the idea originated with Arthur L. Pope, also eighteen years of age. Pope recognized an opportunity to gather together like minds throughout Oregon through 
a small periodical called The Oregon Naturalist. The members of the group were mostly in their teens, boys who collected eggs, nests, and bird specimens as a hobby. ${ }^{1}$

In the fall of 1894 G.B. Cheney of Oregon City began publishing the Oregon Naturalist. Small naturalist journals like these appeared around the country, frequently produced by collector-traders of nests, eggs, bird skins, rocks, and the like, who used the journals to advertise their goods. ${ }^{2}$ Cheney absorbed the subscriptions of The Naturalist of Texas, which had previously acquired the subscribers of a similar natural history publication in Des Moines, Iowa. He successfully solicited submissions and advertising from around the country almost immediately, giving the small journal a national reach. The Oregon Naturalist also enabled bird enthusiasts in Oregon to sell egg sets or bird skins, share findings, and then, to organize. ${ }^{3}$

Announcements of the NOA's formation appeared in the journal, suggesting interested parties contact local oologists Arthur L. Pope and D. Franklin Weeks. At the January 1895 meeting of the NOA Pope was elected president and Finley first Vice President. ${ }^{4}$ The group's immediate goal was to compile an Oregon bird list, as there was no comprehensive list of bird species in the state. The Oregon Naturalist became the NOA's official publication, although it continued to publish news from other small groups, such as the Wilson Ornithological Club, which had begun as a small

\footnotetext{
${ }^{1}$ George A. Jobanek, “The Northwestern Ornithological Association," Oregon Birds: The Quarterly Journal of Oregon Field Ornithology, 24, no. 1 (Spring 1998): 11-17.

${ }^{2}$ Mark V. Barrow, Jr., A Passion for Birds: American Ornithology After Audubon (Princeton University Press: Princeton, New Jersey, 1998), 14-15.

${ }^{3}$ George Jobanek, "The Northwestern Ornithological Association."

${ }^{4}$ Oregon Naturalist (Sept. 1894):8; Oregon Naturalist as The Naturalist (Dec. 1894):14-15; Oregon

Naturalist as The Naturalist (Jan 1895):16.
} 
corresponding group in $1886 .{ }^{5}$ A. B. Averill, a dealer, soon took over as editor. He began an exchange column and offered shells, agates and arrowheads for sale. Other naturalist journals, such as The Nidiologist and Gameland, both published in New York, and dealers in bird skins, eggs, rubber stamps, shells, coins, minerals, taxidermy tools, and "Indian relics" from across the country, all advertised in the Oregon Naturalist. ${ }^{6}$

Pope stepped down as the organization's leader after the first year and Finley, then about nineteen, became president. ${ }^{7}$ Portland area members of the group began meeting monthly at the Finleys' home. Finley pushed for serious papers from the members, concerned that the NOA be perceived as a scientific organization, rather than a group with primarily commercial interests in egg collection. He encouraged members to donate from personal collections to establish an NOA collection that could be used for study by the all members. ${ }^{8}$ A few older and more established ornithologists became associated with the group, including A.W. Anthony and Harvard-educated Frederick. L. Washburn, a zoology and entomology professor at the University of Oregon. ${ }^{9}$ By the beginning of 1896, the group had grown to twenty-two members. Annual dues were 50 cents. $^{10}$

\footnotetext{
5 The Wilson Ornithological Society (WOS) still operates, with a membership of about 2500, and has retained its original support for the contributions of serious amateur ornithologists. The WOS publishes two journals and provides a number of small grants for ornithological research.

${ }^{6}$ Oregon Naturalist, (March 1895).

${ }^{7}$ Shortly after this meeting, Pope sold his entire collection of eggs, in order to put his energy into his work as a journalist at the Yamhill County Reporter. He was also diagnosed with tuberculosis. Jobanek, "The Northwest Ornithological Association."

8"N.O.A." Oregon Naturalist, (May 1896):72; "To the Members of the N.O.A." Oregon Naturalist, (Nov. 1896): 145.

${ }^{9}$ Oregon Naturalist (Oct. 1895):128.

${ }^{10}$ Oregon Naturalist (Jan.1896):3, 6.
} 
For the NOA's third annual meeting in December 1896, the general public was invited to view members' collections, including mounted bird specimens and an extensive display of eggs in the auditorium of Willamette University in Salem. Finley opened the meeting by introducing the organization and its work, and concluded by condemning the "mercenary" selling or exchange of eggs as practiced by "the average pseudo ornithologist."11

At the meeting Finley was once again elected president. Several committees were established. Bohlman was elected chair of the Literature and Museum Committee, which took on the responsibility of classifying specimens sent in by members and working to implement Finley's idea of a NOA collection. Making up a special committee to work to eradicate the English sparrow, Finley and C. F. Pfluger sought "through the agency of the press ...to arouse public opinion against the pest."12

The NOA was one of several naturalist-focused associations being organized in Portland at the time. Portland in the 1890s was growing rapidly. The population more than doubled between 1880 and 1890, and in 1891 the towns of Albina and East Portland joined the city, bringing the city population to about $62,000 .{ }^{13}$ The city had recently connected to the Northern Pacific and Southern Pacific Railways, two bridges spanned

\footnotetext{
${ }^{11}$ The Oologist, Albion, NY. vol. 14-15, (1897-1898): 55; "Report of the Third Annual Meeting of the N.O.A." Oregon Naturalist, (Jan 1897):6-8.

12 Ibid., 7. The English sparrow, today called the house sparrow, is an introduced species that has been highly successful in North America and sometimes displaces native birds.

13 "Growing Up and Growing Old" Riverviews, (Summer 2016), City of Portland, Bureau of Environmental Services, https://www.portlandoregon.gov/bes/article/534311
} 
the Willamette (the Morrison Street Bridge and the original Steel Bridge), and electric streetcars crossed over the Steel to Albina.

Residents were interested in developing the city's cultural institutions, too. The Library Association of Portland had been established in 1864, and other cultural institutions followed, including the Oregon State Horticulture Society (1885), Oregon Alpine Club (1887), Multnomah Amateur Athletic Club (1891), Mazamas (1894), University Club (1898), and the Oregon Historical Society (1898). The Library Association moved into its own building in 1893, and in 1895 the Portland Art Association created a museum in the library. There was also interest in a science museum. In 1890 the Oregon Alpine Club requested support for a city museum from the Portland City Council, which the council declined. ${ }^{14}$ In 1892 a short-lived Oregon Academy of Sciences announced its goal of creating a natural history museum. ${ }^{15}$ By 1897 the Portland City Council had decided to allow various state science groups to use rooms at City Hall, and the NOA had obtained space in to keep specimens and books for study. Finley and Bohlman made significant contributions to the group's collections, including 75 sets of eggs Bohlman donated in early $1897 .^{16}$

In 1897 Arthur Pope died of tuberculosis at the age of twenty. The NOA had always had difficulty scheduling meetings during the summer months when key members were on vacation or out in the field. Finley was preparing to enter University of

\footnotetext{
${ }^{14}$ Richard Thomas Read, "Institutionalizing Science in Oregon: The Role of the Oregon State Academy of Sciences, 1905-1914” (master's thesis, Oregon State University, 1983), 12-15.

${ }^{15}$ Richard T. Read, "In Pursuit of Professionalism: The Oregon State Academy of Sciences, 1905-

1914," Oregon Historical Quarterly 90, no. 2 (1989): 167-98.

${ }^{16}$ Oregon Naturalist (March-April 1897): 26.
} 
California, Berkeley, and in fall 1897 meetings did not resume. The NOA gradually ceased activity. ${ }^{17}$ However, in 1898 a new organization was formed, with NOA members involved, the John Burroughs Club. ${ }^{18}$ The John Burroughs Club later became the Portland-based Oregon chapter of the Audubon Society, in which Finley played a leadership role when he returned to Portland after his time in California.

Cooper Ornithological Club (1900-1910)

While a student at the University of California Berkeley in 1900, Finley joined the Cooper Ornithological Club, where he met Joseph Grinnell, a California naturalist then doing graduate work in biology at Stanford. Finley and Grinnell became good friends. Over the next decade they worked together on a number of projects, including increasing the membership of the Cooper Club, publication of the Club's journal The Condor, Finley's condor photography series with Herman Bohlman, and a farmers' institute demonstration train.

Finley and Grinnell were about the same age, and like Finley, Grinnell loved birds and the outdoors. Grinnell's father was an Indian agency doctor..$^{19}$ One of Grinnell's earliest childhood memories that occurred during a violent encounter between U.S.

\footnotetext{
${ }^{17}$ Although Oregon Naturalist billed itself as the official journal of the NOA through its last issue in January1898, the last issue with items specific to the NOA was May 1897.

${ }^{18}$ Not well known today, in his lifetime John Burroughs was an extremely popular nature essayist, a friend to John Muir, Theodore Roosevelt, and Walt Whitman, and a member of the 1899 Edward H. Harriman Alaska Expedition.

${ }^{19}$ Shugart claims Grinnell's childhood experiences growing up among the Oglala influenced his perspective as a naturalist, tracing Grinnell's understanding of ecology and his later development of the theory of an ecological niche to the Oglala's knowledge of the land and its species. Herman $\mathrm{H}$. Shugart, Foundations of the Earth: Global Ecological Change and the Book of Job (New York: Columbia University Press, 2014), 184.
} 
soldiers and Oglala Sioux at Pine Ridge Reservation. Young Grinnell poked his head out of a tent, fascinated by the dust swirls kicked up by bullets, and Red Cloud's wife Pretty Owl summarily yanked him back in. ${ }^{20}$ Grinnell's mother was a writer-naturalist, and after the family settled in Pasadena, they called their family home "The Birds' Retreat."21 Grinnell had wanted to attend Stanford after graduating from Pasadena High School, but as he later wrote, "my age was sixteen, bulk small, trousers short, and those about me were obsessed with the idea that I was distinctly too infantile to be permitted away from home." ${ }^{22}$ Instead, Grinnell studied biology at Throop Polytechnic Institute (later California Institute of Technology), graduating in 1897. He took two extended trips to Alaska in 1897 and 1898. In addition to collecting bird specimens, he hunted for gold in Nome during the Klondike Gold Rush. Returning to California, he did graduate work at Stanford, receiving his MA in 1901 and a doctorate in 1913. In 1908, he became director of the new Museum of Vertebrate Zoology at UC Berkeley, founded by explorer, collector and philanthropist Annie Montague Alexander, whom Grinnell had impressed with his intelligence and sound advice prior to her own trip to Alaska. ${ }^{23}$

A history of the Cooper Club from 1926 describes with tongue-in-cheek "various radical and startling departures from current usage [that] have appeared from Grinnell's pen at intervals." ${ }^{24}$ At a time when professional ornithologists focused on labwork and

\footnotetext{
${ }^{20}$ E. Raymond Hall, “Obituary: Joseph Grinnell,” The Murrelet 20 (1939): 46-47. Grinnell's mother had left him in Pretty Owl's care.

${ }^{21}$ Hilda Wood Grinnell, “Joseph Grinnell 1877-1939,” The Condor 62, no 1 (Jan-Feb 1940): 4.

22 Jean M. Linsdale, “In memoriam: Joseph Grinnell,” Auk 59 (1942): 269-270.

${ }^{23}$ Annie Alexander to Hilda Wood Grinnell, June 4, 1939, Joseph and Hilda Wood Grinnell Papers, BANC MSS 73/25 c, The Bancroft Library, University of California, Berkeley.

${ }^{24}$ Harry Schelwald Swarth, A Systemic History of the Cooper Ornithological Club (San Francisco: n.p., 1929), 41.
} 
descriptions of physiology he was noted for his original, systematic, and inclusive approach to record-keeping and reporting. A colleague at the Museum of Vertebrate Zoology remembered Grinnell's exhortation to "Put it all down! You may not think it's important but somebody may." ${ }^{25}$ Grinnell stressed the importance of comprehensive observation. Later he developed the significant concept of an ecological niche in relation to species and their habitats. Grinnell also had a reputation as "splitter" (as opposed to a "lumper") for his tendency to divide species into subspecies, based in part on finer distinctions in physiology. ${ }^{26}$ This approach to taxonomy required careful consideration of numerous examples of a species, and Grinnell amassed one of the largest collections of specimens in the country for the Berkeley Museum of Vertebrate Zoology. To do this entailed maintaining relationships with collectors, and Grinnell, like many ornithologists of his day, advocated continued collection for science, while discouraging it as a commercial practice. Grinnell also had extensive knowledge of where specific bird species might be found in California, making him a valuable resource for the photography team of Finley and Bohlman.

This was important to Finley because in the early 1900s he and Bohlman moved from simply camera hunting to focusing on documenting the life cycle of various western

\footnotetext{
${ }^{25}$ Excerpt of oral interview with Ward Russell, the Museum of Vertebrate Zoology's preparator for 40 years; conducted at his home in Berkeley, California, March 4, 1992 by Oliver P. Pearson, Professor Emeritus and former MVZ Director: Audio clip available on Museum of Vertebrate Zoology website, http://mvz.berkeley.edu/Grinnell_Method.html

${ }^{26}$ The terms "splitter" and "lumper" were commonly used in the debate over nomenclature that took place in the late nineteenth and early twentieth centuries. See Barrow, A Passion for Birds, especially chapter four "Nomenclature Reform." For an example of the types of arguments that raged, see Joseph Grinnell and Witmer Stone, "The Functions of the A. O. U. Committee on Nomenclature," The Auk 29, no. 4 (1912): 561-68.
} 
bird species. One of Finley and Bohlman's more ambitious goals as photographers was to do a life cycle series of condors. The bird's increasing rarity was then driving its desirability among collectors, who persisted in spite of a 1905 California state law prohibiting killing condors or taking their eggs. Grinnell shared the location of a nesting pair with Finley, who with Bohlman, in 1906 took an extensive series of photographs of the adults and the developing nestling.

Through his work with the Cooper Club, Finley also established ties with other naturalists and with trained scientists through connections to members of the American Ornithologists Union (AOU) and the Bureau of Biological Survey. In 1901 Joseph Grinnell was elected to the AOU, at age 24 the youngest fellow until that date. As an AOU member, Grinnell pushed for representation from the West and inclusion of information about Western species on official lists. ${ }^{27}$ He published an invitation in The Condor to members of the AOU to attend the Cooper Ornithological Club's celebration of its tenth year, and in May 1903 thirteen members of the AOU, along with 31 family members and friends, went by train from Chicago west to San Francisco to attend. ${ }^{28}$ The California Academy of Sciences in San Francisco hosted the meeting over a period of two days.

At the meeting Finley had the opportunity to meet important people in American ornithology and present his field and photography work with Bohlman. C. Hart Merriman, Director of the Bureau of Biological Survey, a founder of the National

\footnotetext{
${ }^{27}$ Linsdale, "In memorium: Joseph Grinnell."

${ }^{28}$ The visitors also took the opportunity to see some of the sights out West, stopping to see the Grand Canyon, the Petrified Forest and the Mohave Desert, as well as visiting Santa Fe and Los Angeles.
} 
Geographic Society, and friend of Theodore Roosevelt's, opened the meeting. Among the presenters were Frank M. Chapman of the American Museum of Natural History in New York, a photographer and the originator of the Audubon Christmas Bird Count tradition, and well known New York artist, explorer, and ornithologist Louis Agassiz Fuentes. Theodore Sherman (T.S.) Palmer, who also worked for the Biological Survey and later served as president of the National Audubon Society, was present. Finley gave a well received lecture on Oregon birds using lantern slides, emphasizing life cycles of various western species. ${ }^{29}$

For Finley the meeting was a great success. He made connections with people with whom he would later work closely, and who were in positions to influence policy regarding wildlife protection legislation and decisions about specific locations to be protected. Chapman would later use some of Finley and Bohlman's photographs to illustrate one of his books, Finley would go on to do field work for the Biological Survey, and to work with the Survey in his capacity as Game Warden and State Biologist with the Oregon Game Commission. He also worked closely with Palmer, who held key positions in both the Bureau of Biological Survey and National Audubon. In 1905 Finley was elected an associate member of the AOU, a special tier that had been created to accommodate non-professionals without formal scientific training. ${ }^{30}$

\footnotetext{
29“"Joint Meeting of the American Ornithologists' Union and the Cooper Club of California," The Condor 5, no. 4 (July-Aug. 1903): 108-109.

${ }^{30}$ Jno. H. Sage, “Twenty-second Congress of the American Ornithologists' Union,” The Auk 22, no. 1, American Ornithologists' Union, 1905: 71-76.
} 
In Finley's relationship with Grinnell one sees how, despite the development of ornithology as a specialized and professionalized field, important roles remained for the expert amateur. Finley was particularly involved in The Condor. He contributed regularly, and as an associate editor strategized with Grinnell about how to attract more subscribers and weighed on issues such as the merits of simplified spelling. His articles and the Finley-Bohlman photographs were a selling point for potential subscribers. As an organization, the Cooper Club aimed to be a science-based organization that also served the needs and interests of non-professionals. Finley's work was accessible to the layperson, and interesting for the scientist, too. Finley tried to promote the journal and Cooper Club at his lectures while avoiding the appearance of pushing his own written work. He and Bohlman also offered prints of their work as premiums to new members. Finley's association with the Cooper Club allowed him to contribute to ornithological knowledge through his detailed descriptions of photography trips in the field. His first piece appeared in The Condor in 1901, and he served as an associate editor from 1906 to 1909. It was in The Condor that Finley and Bohlman first began publishing their work. Finley published a number of early versions of his stories of his field expeditions with Bohlman that he later adapted for a variety of other publications, including general interest magazines such as Pacific Monthly and Sunset.

Finley went to the 1904 annual AOU meeting in Cambridge, Massachussetts, the year after AOU members came to visit the Cooper Club in California. He gave a lecture to the AOU and "his excellent pictures and his eloquence in describing them" impressed 
the members. ${ }^{31}$ His lectures were valued for the intelligent observations they contained, as well as the exceptional photographs he used to illustrate them. William Dutcher, national Audubon's first president, made Finley a field agent for National Audubon in 1904 in part of the strength of his ability to lecture.

Audubon Society (1902-1911)

In 1898, while Finley was at university in California, a new ornithology group was formed in Portland, the John Burroughs Club. By 1902 the group had changed its name to the Oregon Audubon Society and affiliated with the National Societies of Audubon. Finley joined the Oregon Audubon Society in 1902 and quickly assumed a leadership role. By 1906 he was its president.

Through Audubon, Finley joined other Progressives to campaign for legislation to protect wildlife, fund enforcement of protection legislation, and educate the public about bird protection. In this way, Finley's early Audubon leadership became a proving ground for his later role with the Oregon Game Commission, as well as his later activism on behalf of clean waterways, including wetlands and riparian habitat. His involvement with Audubon led him to one of his defining concerns as a conservationist, the nesting and resting grounds of the Klamath Basin along the Pacific Flyway discussed in chapter three.

In Portland, Audubon was preceded by other organizations of bird enthusiasts. The NOA had emphasized the education of its own members through field work and collections of specimens. The Society for the Introduction of Useful Songbirds (also

31 "New Bird Photographer," Evening star, Washington, D.C., Nov. 22, 1905. 
known as the Songbird Club) was established to introduce European songbirds to the Portland area. ${ }^{32}$ In 1898 Reverend William Rogers Lord initiated the John Burroughs Club, named for the popular nature writer. ${ }^{33}$ Club goals included appreciation and protection of birds. Some of the NOA were charter members. Finley was in the middle of his university program at University of California, Berkeley and spending much of his time in California. However, Bohlman served as treasurer, a role he continued for many years. $^{34}$

The idea of an "Audubon Society" was begun by George Bird Grinnell in 1886 in an editorial in Forest and Stream. ${ }^{35}$ Grinnell soon had thousands of members. He was quickly overwhelmed by work, especially as he also began the Boone and Crockett Club with Theodore Roosevelt in 1887 , so he ended the Audubon project after a few years. In 1896 Harriet Hemenway of Boston and her cousin Minna Hall revived it. They began organizing wealthy women like themselves to boycott feather decorations in fashion.

\footnotetext{
${ }^{32}$ In 1889 the Songbird Club released 275 pairs of songbirds imported from Germany in Portland. In 1892 they released more, attempting to establish thirty different species of European songbirds altogether. Although a Portland resident reported hearing a nightingale singing near his home throughout the summer of 1890 , only the skylarks and starlings survived long. In 1891 A.W. Anthony wrote that Portlanders were unaware of how many native songbirds were in the area and mistakenly ascribed birdsong they heard to introduced birds. In 1908 Dr. Joseph Grinnell termed the Songbird Club "idiotic" with a comment from William Finley that perhaps the enthusiasm stemmed from the successful establishment of Chinese pheasants for sport hunting in Oregon. A.W. Anthony, "Oregon's Imported Songsters," Zoe 2 (1891): 6-11; "Editorials," The Condor10, no. 1 (Jan-Feb 1908): 51-52.

${ }^{33}$ Audubon Society of Portland gives the date for the John Burroughs Club as 1898, but Frances S. Twining states 1900 after consulting the JBC minutes book. Herman Bohlman's treasurer's book for the Oregon Audubon Society shows a transfer of funds from JBC to Oregon Audubon Society as of 1901. The JBC minutes book unfortunately seems to have been lost. Tom McAllister, "Our First 50 Years-19021952," Audubon Society of Portland website, under History. http://audubonportland.org/files/first50; Frances S. Twining "Early History of Bird Societies." Typescript noted Sunday Oregonian, October 9 , 1927, Box 27, MSS 2990, Oregon Audubon Society Records, Oregon Historical Society Research Library, Portland, Oregon (hereafter cited as OAS); Account Book 1901-1930, OAS.

${ }^{34}$ Finley first appears in the account book as a paying member in July 1902. Account Book 1901-1930, OAS.

35“"The Audubon Society,” Forest and Stream 26 (Feb. 11, 1886): 41.
} 
Hemenway and Hall also recruited New England ornithologists and writers to help with the cause. They established the Massachusetts Audubon Society in 1896; other state societies soon followed. In 1901 societies joined together as part of a National Committee of the Audubon Societies, which incorporated in 1905 as the National Association of Audubon Societies. ${ }^{36}$

In early 1902, John Burroughs Club Secretary Gertrude Metcalf sent an inquiry

from Portland to the National Committee about a formal affiliation with the National Committee of the Audubon Societies. Mabel Osgood Wright, Committee Secretary, responded with a request that the John Burroughs Club change its name to Audubon, as the National Committee wanted to ensure each state was represented by just one organization. ${ }^{37}$ In fact, an Audubon Society had recently been organized in Astoria that

\footnotetext{
${ }^{36}$ For the history of the National Audubon Society see Frank Graham Jr., The Audubon Ark: A History of the National Audubon Society (1st University of Texas Press ed. Austin: University of Texas Press, 1992); Oliver H. Orr, Jr. Saving American Birds: T. Gilbert Pearson and the Founding of the Audubon Movement (Gainesville: University Press of Florida, 1992); Jennifer Price, "When Women Were Women, Men Were Men, and Birds Were Hats" in Flight Maps: Adventures with Nature in Modern America (New York: Basic Books, 1999); Kathy S. Mason "Out of Fashion: Harriet Hemenway and the Audubon Society, 18961905." Historian 65, no. 1 (2002): 1-14. Carolyn Merchant Spare the Birds!:George Bird Grinnell and the First Audubon Society (New Haven: Yale University Press, 2016).

${ }^{37}$ Mabel Osgood Wright to Gertrude Metcalf, Feb. 2, 1902, Correspondence, General 1902-1957, OAS. Wright was a self-trained naturalist and writer who founded the Connecticut Audubon Society in 1898 and served as its president for the next twenty-six years. In 1899 Wright began assisting Frank Chapman in editing Bird-Lore, a magazine he created to serve a popular audience, which later became the official publication of the National Audubon Societies. When National Audubon incorporated in 1905 Wright served on the Board of Directors and continued to work on Bird-Lore though T. Gilbert Pearson took over as secretary. For more on Wright's career see Carolyn Merchant, "Women of the Progressive Conservation Movement, 1900-1916," Environmental Review 8 (spring 1984); Kim Perez. "'Nature as a Field for Fiction': Mabel Osgood Wright Responds to the Nature Faker Controversy." Interdisciplinary Studies in Literature and Environment 19, no. 1 (2012): 24-42; Thomas R. Dunlap, In the Field, Among the Feathered: A History of Birders and Their Guides, (New York: Oxford University Press, 2011), 32-33; Daniel J. Philippon, Conserving Words: How American Nature Writers Shaped the Environmental Movement (Athens: University of Georgia Press, 2004), 72-100.
} 
included members from around the state, including the Portland area. ${ }^{38}$ In 1902, the two groups combined as the Oregon Audubon Society.

Initially focused on outreach and raising funds, Oregon Audubon organized regular lectures and accepted donations at the door. The first lecture was on November 8 , 1901 when Bohlman and Ross Nicholas, another former NOA member, gave a "steriopticon entertainment." ${ }^{39}$ Some lectures were more profitable than others. Lord, the Jon Burroughs Club founder, had gone back to his native New England but visited the West Coast several times on lecture tours. His May 7, 1902 lecture in Portland netted over forty-eight dollars, but after his $\$ 35$ fee and various costs for use of the hall, a slide lantern, and so on were paid, Oregon Audubon only made $\$ 5$. On the other hand, on January 7, 1903 Finley was in town, and he and Bohlman gave a steriopticon entertainment without any fee for themselves. That brought in $\$ 23.75 .^{40}$ The group also paid members commissions for the recruitment of new dues-paying members.

In 1903 Finley graduated from University of California Berkeley with a BA in History and Philosophy. He stayed on at Berkeley the following year, enrolled as a graduate student and worked as a Reader in the English Department. He also took an

\footnotetext{
${ }^{38}$ William Dutcher to Gertrude Metcalf, June 19, 1902, Correspondence, General 1902-1957, OAS. ${ }^{39}$ This event was technically a fundraiser for the JBC but all JBC money was transferred to OAS. A stereopticon is a type of so-called magic lantern, a slide projector used to show images on glass plate slides, sometimes hand painted. By the early 1900s, the term was in general use for a variety of slide projectors, including those projecting a single view and those with double lenses allowing for a dissolve effect between images. For a discussion of the usage of the term stereopticon and related words during the nineteenth century see Kentwood D. Wells, "What's in a Name? The Magic Lantern and the Stereopticon in American Periodicals 1860-1900," The Magic Lantern Gazette 20 (Fall 2008): 3-19.

${ }^{40}$ Account Book 1901-1930, OAS.
} 
appointment as a field agent for National Audubon. ${ }^{41}$ The Oregon Audubon chapter was dividing its time between education and enforcement of bird protection laws. Members organized bird talks and field trips, such as a sunrise hike and picnic. Oregon Audubon also distributed printed notices regarding game laws. Oregon's State Game Warden had hired deputy wardens for the Klamath region in southeastern Oregon, with money contributed by both the state and from Audubon. ${ }^{42}$ National Audubon had begun working on enforcement of new game laws by funding the salaries of game wardens and inspections of important bird habitats by Audubon representatives.

In fall of 1905, Finley gave a lecture for the Audubon Society of Washington, DC as a fundraiser for the family of Florida game warden Guy Bradley, who had been killed while trying to arrest a plume hunter. ${ }^{43}$ Finley used lantern slides and explained the methods he and Bohlman used to get their shots, such as habituating birds to the cameras and enticing birds with food. They obtained a photograph of a humming bird feeding from a flower by putting sugar water in the flowers to draw the bird (Figure 19).

\footnotetext{
${ }^{41}$ University of California, Berkeley. (1904) Register-University of California. University of California Press. HathiTrust Digital Library. Finley seems to have been the only at-large agent in 1904, representing the Pacific Coast region. In 1907 Edward Howe Forbush, another self-taught writer naturalist, became field agent for New England.

42 "State Reports: Oregon" Bird-Lore 7, no. 1 (Jan-Feb 1905): 103-108.

43 "New Bird Photographer"; "Lecture on Bird Life," Evening Star, Washington, D.C., November 25, 1905. OAS also sent a $\$ 10$ contribution to the fund. April 2, 1906 entry, Account Book 1901-1930, OAS.
} 


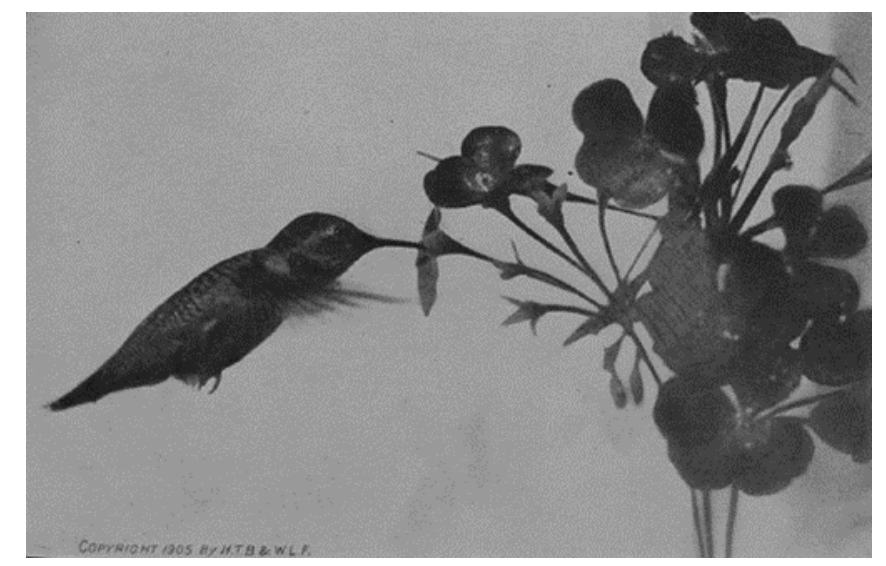

Figure 19. Hummingbird feeding on the wing. William L. Finley, American Birds, opposite page 12. www.kellscraft.com

In 1906 Finley became president of Oregon Audubon, taking over from A.W. Anthony. He pushed for more attention to the situation in the West. The photography trips Finley and Bohlman took to Southern Oregon (covered in chapter three) were partially in response to National Audubon President William Dutcher's request for more information on conditions there. By the time they took a second trip in 1908, the local Audubon chapter was able to cover four hundred dollars of their expenses. ${ }^{44}$

In 1904, from his position as an official representative of Audubon, Finley began giving lantern lectures around the country, taking with him slides of the photographs he and Bohlman had taken. In some cases, his talks were free, arranged under the auspices of Audubon. In other cases, Finley requested a fee to cover his costs. Within a few years, his talks were in demand. During 1908 and 1909, in addition to giving talks in Oregon, Finley gave Audubon-sponsored lectures on the protection of birds illustrated with

${ }^{44}$ Entries for May 2, 1908 and April 10, 1909, Account Book 1901-1930, OAS. 
lantern slides in Grand Forks, Fargo, St. Paul, Madison, Chicago, Indianapolis, Cincinnati and Detroit. He also gave eight talks in Washington State, some at teacher institutes. In August 1909 he spoke at the Annual National Irrigation Congress in Spokane. Finley believed this was an important audience of "practical men" and felt that if farmers and loggers understood the economic value of birds, especially song birds, there would be more support for their protection and more patience with damage to fruit and other crops. Later in August he spoke at the National Conservation Congress in Seattle as a representative of Audubon. ${ }^{45}$

In February 1909 Oregon Audubon put milliners on notice that the 1903 Model Bird Law of Oregon, which prohibited having on hand for sale plumes from protected birds, would be enforced. The milliners believed the law did not apply unless it could be shown that the bird feathers had been taken in Oregon. They asserted their feathers were imported and continued business as usual. However, a recent U.S. Supreme Court decision had indicated possession of a prohibited bird could be prosecuted, even if the bird or bird parts had been imported. ${ }^{46}$ April 2, 1909, "was one rather hectic morning... when the Finleys and Mr. Bohlman made the rounds of a number of millinery houses that persisted in selling aigrettes." ${ }^{47}$ Finley, as Oregon Audubon Society President and a deputy state game warden, arrested ten millinery proprietors for violating the law. A few days later he rearrested milliners at Meier \& Frank and Lipman, Wolfe \& Company department stores for continuing to do so. The action was a success; the

45 "Report of William L. Finley," Bird-Lore 11, no. 6 (December 1909): 301-304.

${ }^{46}$ Silz v Hesterberg, 211 U.S. 31 (1908). See casetext. https://casetext.com/case/silz-v-hesterberg

${ }^{47}$ Frances S. Twining, "Early History of Bird Societies." 
milliners pledged to get rid of the feathers they had for sale and canceled their orders for the next season. ${ }^{48}$

In addition to taking action against milliners, Finley pulled together a patchwork of funding to protect the birds in the Klamath Basin. He reported to the National Audubon organization that Oregon Audubon Society had raised $\$ 300$ to contribute to paying the salaries of wardens at Klamath and Malheur Lakes. ${ }^{49}$ However, the Oregon Audubon Society sent just two hundred dollars to National Audubon. ${ }^{50}$ The remaining $\$ 100$ would be used to create a boat launch for the warden at Malheur Lake. ${ }^{51}$ Finley arranged for Oregon Audubon to send an additional \$12 a month directly to one of the Southern Oregon wardens, L. Alva Lewis. ${ }^{52}$ Oregon Audubon also raised money toward the expense of a boat, "the Grebe" for Lewis to use while patrolling. ${ }^{53}$

In late summer 1910 Finley began planning a cross-country lecture tour for Audubon as he had done in previous years. However, he put it aside after receiving a request from Dr. Theodore S. Palmer, Vice-President of National Audubon. ${ }^{54}$ Palmer was also Assistant Chief for the Bureau of Biological Survey, and Finley had just completed some Survey work for him, inspecting bird reservations in the Southwest while on a

\footnotetext{
48 “Law Enforcement in Oregon,” Bird-Lore 11, no. 4 (August 1909): 188.

49 Ibid.

${ }^{50}$ Entries for May 15, 1909 and Oct. 4, 1909, Account Book 1901-1930, OAS.

51 "State Reports: Oregon," Bird-Lore 11, no. 6 (December 1909): 328-329.

${ }^{52}$ Lewis had served as president of the Oregon Retail Jewelers Association in Klamath Falls and would support Finley in his bid to become State Game Warden in 1910-1911. However, in the early 1920s he was one of the squatters on the California side of Lower Klamath Lake after the lake had dried out, trying to claim the land for small-scale ranching. Doug Foster. "Refuges and Reclamation: Conflicts in the Klamath Basin, 1904-1964," Oregon Historical Quarterly 103, no. 2 (2002): 150-87.

${ }^{53}$ Entries for March 4, 1911 and May 20, 1911, Account Book 1901-1930, OAS.

${ }^{54}$ Palmer was also serving as Secretary to the AOU.
} 
photography expedition with his family. Now Palmer asked him to put together an exhibit car for a demonstration train in California, and to consider it part of his Audubon work.

Demonstration trains were a briefly popular offshoot of farmers' institutes, which aimed to provide farmers with information related to agriculture and other aspects of rural life. California's first train ran in 1909, and included cars with exhibits, set up for demonstrations, as well as a car for lectures illustrated with lantern slides. Dining and sleeping cars were attached for the staff and lecturers who traveled with the train. The 1909 train made 197 stops in California and was visited by 37,270 people. ${ }^{55}$

Palmer suggested Finley, representing Audubon, work with Joseph Grinnell and two other UC Berkeley professors on the project, go to California in mid-September to make arrangements and then provide lectures on the train. ${ }^{56}$ Finley liked the idea. He believed in the economic value of birds to agriculture and wanted to convince farmers of it. On the other hand, accepting the demonstration train project presented Finley with a scheduling problem.

The exhibit car needed to be pulled together quickly and if Finley were to go to California in September, he would have little time to prepare an October lecture tour. Finley had planned to give lectures across the Midwest for Audubon on his way to the annual meetings of National Audubon and the American Ornithologists Union in New

55 Jeffrey W. Moss and Cynthia B. Lass, "A History of Farmers' Institutes," Agricultural History 62, no. 2 (1988): 150-63.

${ }^{56}$ William Finley to William Dutcher, Aug. 1, 1910; Theodore S. Palmer to Finley, Aug 27, 1910, Folder 1: Correspondence, Oct. 1909-Oct. 1910, Box 20, Series 3, William L. Finley Papers, 1899-1946 (MSS Finley), Oregon State University Special Collections and Archives Research Center, Corvallis, Oregon (hereafter cited as Finley Papers, OSU). 
York City in late October. ${ }^{57}$ After the meetings he would do some talks arranged independently, for a fee. He had already begun writing to contacts in New York, Boston, Philadelphia and Chicago offering his services with proposed speaking fees ranged from twenty-five to fifty dollars, depending on circumstances. ${ }^{58}$

Finley was concerned about the tour, though. He had been ill during the family's trip to California and the Southwest. He admitted to Joseph Grinnell that he did not have much fresh material to offer on the lecture circuit and was feeling pressed to get some magazine articles out for pay. On August 1st, Finley wrote National Audubon President William Dutcher to say that Theodore Palmer had suggested Finley take on the demonstration train work in California, and that with that and other matters he would have to cancel his trip East. He seems to have been of two minds about it, however, as he continued to make arrangements for the trip, and then at the end of August began writing to express his regrets that he would be delaying his trip "on account of my publishers." 59

Finley had by 1910 made a name for himself as a photographer-writer-naturalist. He lectured around the country, and had published in many popular magazines. His first book, American Birds, (1907) was a success. Newspapers reported Kermit Roosevelt would be using the "William L. Finley method" of wildlife photography and that

\footnotetext{
${ }^{57}$ Dutcher to Finley, July 22, 1910, Folder 1, Finley Papers, OSU.

${ }^{58}$ William Finley to Franklin W. Hooper, Brooklyn Institute of Arts \& Sciences, June 15, 1910; Hooper to Finley, July 1, 1910; Finley to Hooper, July 15, 1910; Finley to William Rogers Lord, July 27, 1910; Finley to Henry H. Kimball, July 27, 1910, all in Folder 1, Finley Papers, OSU.

${ }^{59}$ Finley to William Dutcher, Aug. 1, 1910; Finley to Francis Harper, Aug. 3, 1910; Finley to F.A. Lucas Aug. 3, 1910; Finley to Franklin W. Hooper, Aug. 3, 1910; Beecher S. Bowdish to Finley, Aug. 16, 1910; Finley to Frederick Skiff, Aug. 27, 1910; Finley to William Rogers Lord, Aug. 27, 1910, Folder 1, Finley Papers, OSU.
} 
Theodore Roosevelt had requested Finley visit his son to give him some tips in preparation for Roosevelt's controversial collecting expedition for the Smithsonian. ${ }^{60}$

However, Finley still worried about money. In 1910 he was receiving a salary of $\$ 1,200$ a year as a field agent for National Audubon, comparable to the salary of a bank clerk or federal government employee. ${ }^{61}$ On the other hand, Finley was expected to cover most of his expenses for Audubon work and did not receive additional compensation for his Audubon lectures. He traveled a great deal to lecture and lobby, and had by then a wife and two young children. During the summer of 1910 Finley worked with his New York writing agent to get articles placed in paying magazines, negotiated with Sunset, then a promotional magazine for Southern Pacific Railroad, for credit or reimbursement of train tickets, and struggled to get the Bureau of Biological Survey to reimburse miscellaneous travel expenses for inspection work done in June in Arizona and New Mexico. ${ }^{62}$

Although he was tired from illness, behind in his writing, and possibly concerned about finances, Finley was enthusiastic about the demonstration train project because he believed that it was essential to have broad support, including from farmers, to ensure

60 "Roosevelt to Secure Photographs of Birds," San Francisco Call, Vol. 105, No. 106, March 16, 1909. "Hunting Wild Birds with the Camera" Camera Craft, 17, no. 3 (March 1910): 127. Although the invitation was reported in the media, an actual visit was not, so may not have occurred. Roosevelt collected many scientific specimens for the Smithsonian, but was accused of killing too many animals and of undertaking the trip more for the joy of the hunt than for the sake of science.

${ }^{61}$ By comparison, in 1910 a civilian employee of the federal government averaged 1071.00 in annual salary, an employee in finance or real estate 1263.00, and a teacher as little as 546.00. See Historical Statistics of the United States Millennial Edition Online, Table Ba4335-4360. https://hsus.cambridge.org ${ }^{62}$ F.M. Holly to Finley, June 10, 1910; Finley to Holly, June 15, 1910; Holly to Finley, July 18, 1910; Finley to Holly, July 27, 1910; Sunset to Irene Finley, April 16, 1910; William Finley to Sunset, Aug. 26, 1920; Sunset to Finley, Sept. 17, 1910; Theodore S. Palmer (Bureau of Biological Survey) to Finley, June 30, 1910; Henry Oldys to Finley, Aug. 16, 1910, Folder 1, Finley Papers, OSU. 
wildlife protection. He welcomed the opportunity to put together a convincing exhibit on the importance of bird protection, especially on the economic value of birds ${ }^{63} \mathrm{He}$ convinced the California Fish and Game Commission to allocate one hundred dollars for materials, which he planned to us for some enlarged prints of photographs and mounted specimens for display car. ${ }^{64}$

However, Finley encountered difficulties in the rest of his arrangements. He went to California in September 1910 to work with John P. Babcock of the California Fish and Game Commission and faculty members at the University of California on preparations for the demonstration train. Trouble abounded. First, he found the UC faculty did not want to work with the California Fish and Game Commission. ${ }^{65}$ Next, he discovered the man Babcock had found to staff the exhibit car was prone to drink. ${ }^{66}$ Then he had difficulty getting specimens, the quality of the taxidermist he found in Oregon was low, and his friend Grinnell at Berkeley was not inclined to help. ${ }^{67} \mathrm{He}$ arranged for Gretchen Libby of the California Audubon Society to take charge of the exhibit car in California, planning to go along on the first trip himself and then turn over the education work to her. However, William Dutcher of National Audubon objected to a woman on the exhibition train. Finley settled this with Dutcher, explaining she would not be the only woman on

${ }^{63}$ Finley to William Dutcher, Aug. 1, 1910; Finley to W.T. Clarke, Sept. 3, 1910; Finley to Dutcher, Sept. 15, 1910, Folder 1; Finley to Gretchen Libby, Nov. 11, 1910, Folder 2, Correspondence, Nov. 1910-Dec. 1910, Finley Papers, OSU.

${ }^{64}$ Finley to John P. Babcock, Oct. 14, 1910, Folder 1; Finley to T. Gilbert Pearson, Nov. 9, 1910, Folder 2, Finley Papers, OSU.

${ }^{65}$ Finley to Dutcher, Oct. 11, 1910, Folder 1, Finley Papers, OSU.

${ }^{66}$ Finley to Theodore S. Palmer, Oct. 14, 1910, Folder 1, Finley Papers, OSU.

${ }^{67}$ Finley to Joseph Grinnell, Sept. 14, 1910; Grinnell to Finley, Oct. 17, 1910, Folder 1; Finley to Grinnell, Nov. 2, 1910; Grinnell to Finley, Nov. 3, 1910, Finley to Grinnell, Nov. 9, 1910, Folder 2, Finley Papers, OSU. 
board. ${ }^{68}$ Dutcher also hoped to avoid much expense to National Audubon on the project and recommended Finley solicit the railroad to provide transportation for himself from Oregon to the demonstration train's starting point. The railroad told Finley this was impossible. ${ }^{69}$

At this point, the project was taken away from Finley by faculty at University of California. The California Fish and Game Commission agreed to fund a scholarship of $\$ 1,200$ for a Berkeley graduate student, Harold C. Bryant, whose duties would include managing the train exhibit. ${ }^{70}$ Finley was forced to telegram Gretchen Libby at the last minute to cancel their plans. Although pleased for Bryant, Finley was embarrassed, and had incurred bills related to the project. He expressed his displeasure in a frank letter to his friend Grinnell, who had been involved in the takeover. ${ }^{71}$

A letter from National Audubon reassuring Finley that Audubon would cover the cost of his train travel arrived shortly thereafter. Although Audubon would no longer be directly represented in the exhibit car, Finley put a positive spin on the affair with the National Office. He informed Theodore Palmer and T. Gilbert Pearson of the new arrangement, including the funding of Bryant's graduate studies by the California Fish

\footnotetext{
${ }^{68}$ William Dutcher to Finley, Oct. 4, 1910; Finley to Dutcher, Oct. 11, 1910; Finley to Gretchen Libby, Oct. 11, 1910; Dutcher to Finley, Oct. 25, 1910; Irene Finley to Libby, Oct. 25, 1910, Folder 1, Finley Papers, OSU.

${ }^{69}$ William Dutcher to Finley, Sept. 26, 1910; Dutcher to Finley, Oct. 4, 1910; W.T. Clarke to Finley, Oct. 17, 1910, Folder 1; Finley to T. Gilbert Pearson, Folder 2, Finley Papers, OSU.

${ }^{70}$ Bryant earned his doctorate in zoology, worked for Grinnell at the Museum of Vertebrate Zoology, Berkeley, and later joined the National Park Service as an educator. He helped organize Olympic and Kings Canyon National Parks, and served as superintendent of Grand Canyon National Park from 1941-1954.

${ }^{71}$ W.T. Clarke to Finley, Nov. 7, 1910; Finley to Clarke, Nov. 9, 1910; Finley to Joseph Grinnell, Nov. 9, 1910; Earnest B. Babcock to Finley, Nov. 11, 1910; Finley to Gretchen Libby, Nov. 15, 1910; Grinnell to Finley, Nov. 16, 1910; Finley to Grinnell, Nov. 18, 1910, Folder 2, Finley Papers, OSU.
} 
and Game Commission. The cooperative effort would be "a splendid thing" for bird conservation in California, Finley wrote, and was due to Finley's conversations with University of California faculty and John Babcock of the Fish and Game Commission about the demonstration train. ${ }^{72}$

Finley was feeling constrained by limitations imposed on his work as an Audubon representative from a lack of resources. His frustration led to his campaign for a role in wildlife management for the State of Oregon, though the Audubon work was one of the keys to him getting the job. His contributions to organizations such as Audubon allowed him to demonstrate his leadership abilities and make connections with influential people. He also gained experience in managing game wardens and enforcing regulations.

His organizational work has had a lasting impact. The Northwest Ornithological Association, begun in 1894, was a small group, mostly young men in their teens and twenties, and it existed only a few years. However, it was the nucleus of the later John Burroughs Club, which transformed into the Oregon Audubon Society. This organization is now the Portland Audubon Society, which maintains bird sanctuaries in Portland and on the central Oregon Coast, as well as a wildlife rehabilitation center and an educational facility in East Portland. Portland Audubon today celebrates William L. Finley as a founder and continues his activism on behalf of birds.

The Cooper Ornithological Club of California, later the Cooper Ornithological Society, merged in 2016 with the American Ornithologists Union to become the

\footnotetext{
72 Theodore S. Palmer to Finley, Nov. 15, 1910; Finley to Palmer, Nov. 17, 1910; Finley to Palmer, Nov. 17, 1910, Folder 2, Finley Papers, OSU.
} 
American Ornithological Society, with a mission to develop and disseminate bird science, to use that knowledge to promote bird conservation, and to support professional ornithologists. One of Finley’s earliest pieces, “Catching Birds with a Camera” appeared along with Herman Bohlman photographs in the third year of publication for the Cooper Club's journal The Condor. Today that journal is The Condor: Ornithological Applications, a peer reviewed journal addressing "the application of scientific theory and methods to the conservation, management, and ecology of birds." 73

Finley's involvement benefited these organizations, and he was shrewd enough to make sure he benefited, too, in realizing his goal of a life working for and with wildlife. Finley took advantage of the knowledge of fellow Cooper Club members to find rewarding locations for bird photography in California, and combined inspection work for Audubon in Southern Oregon with field photography. The next chapter explores how he and Bohlman undertook several ambitious projects between 1904 and 1908, going farther afield both in location and aim.

\footnotetext{
73 American Ornithological Society website, http://www.americanornithology.org/content/condorornithological-applications.
} 


\section{Chapter Three}

Farther Afield: Finley and Bohlman 1904-1908

While Finley developed his career as a professional naturalist by building credibility in organizations such as the Cooper Club and in Audubon, he continued to take photographs. Between 1904 and 1908 Finley and Bohlman completed several significant photography projects. They explored the San Francisco Bay Area with their cameras and used their earlier climbing experience to photograph golden eagles in their nest, documented the development of a California condor, and made two trips to important nesting grounds on the Oregon-California border.

By the end of this period, the two men were moving in different directions. Bohlman traded field work for family life and his business, while Finley launched himself into a professional career as a naturalist. Finley was also profoundly affected by their trips to the nesting grounds at Klamath and Malheur. His experiences there resulted in a new urgency to strengthen bird protection.

After Finley graduated in 1903 he set about establishing himself as a writernaturalist, in part by promoting himself and Bohlman as a team. He published accounts of their work in The Condor, which aimed to be a scientific publication. This did not pay, but his regular contributions enhanced his professional reputation. He also targeted general interest magazines such as Pacific Monthly, Sunset, and Everybody's Magazine.

Finley stayed in California, working as a Reader, or teaching assistant, in the English Department at Berkeley. In March 1904 Bohlman joined him in California for 
four months of field work. Finley had identified good locations for photography. The two put their earlier climbing experience to work, photographing golden eagles and herons high in the trees at the southeast end of San Francisco Bay.

They made the trip to the eagles' nest on Mission Ridge in Alameda County six times. ${ }^{1}$ Finley wrote several detailed articles about how they traveled out to the nest. First, they boarded an early morning train in Oakland heading south with bicycles and camera equipment in the baggage car, then they biked as far as possible, hid the bikes and hiked up the ridge. They took pictures during the afternoon and the following morning, reversing the trip the next day. They documented the journey in photographs, setting up shots of themselves with their bikes and gear (Figure 20).

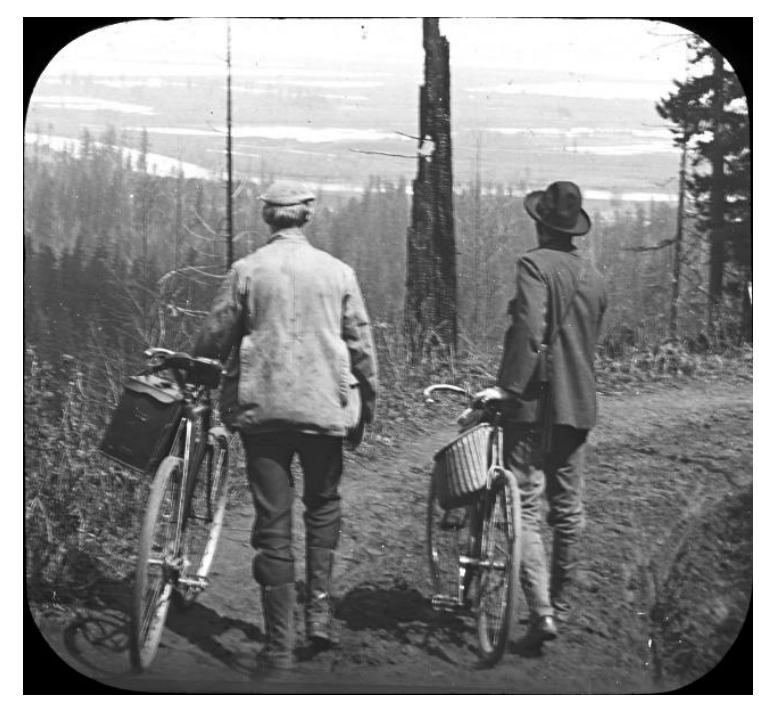

Figure 20. Bohlman and Finley with bicycles in California 1904. Herman T. Bohlman Photograph Collection (P 202: bicycles a), Oregon State University Special Collections and Archives Research Center, Corvallis, Oregon.

\footnotetext{
${ }^{1}$ Today the area is the Mission Peak Regional Preserve in Fremont, California.
} 
They also took photos of themselves in the trees. In one (Figure 21), Bohlman is lying over a branch and passing a plate to Finley who sits farther out on the branch, as two young eagles look on. San Francisco Bay is visible in the distance.

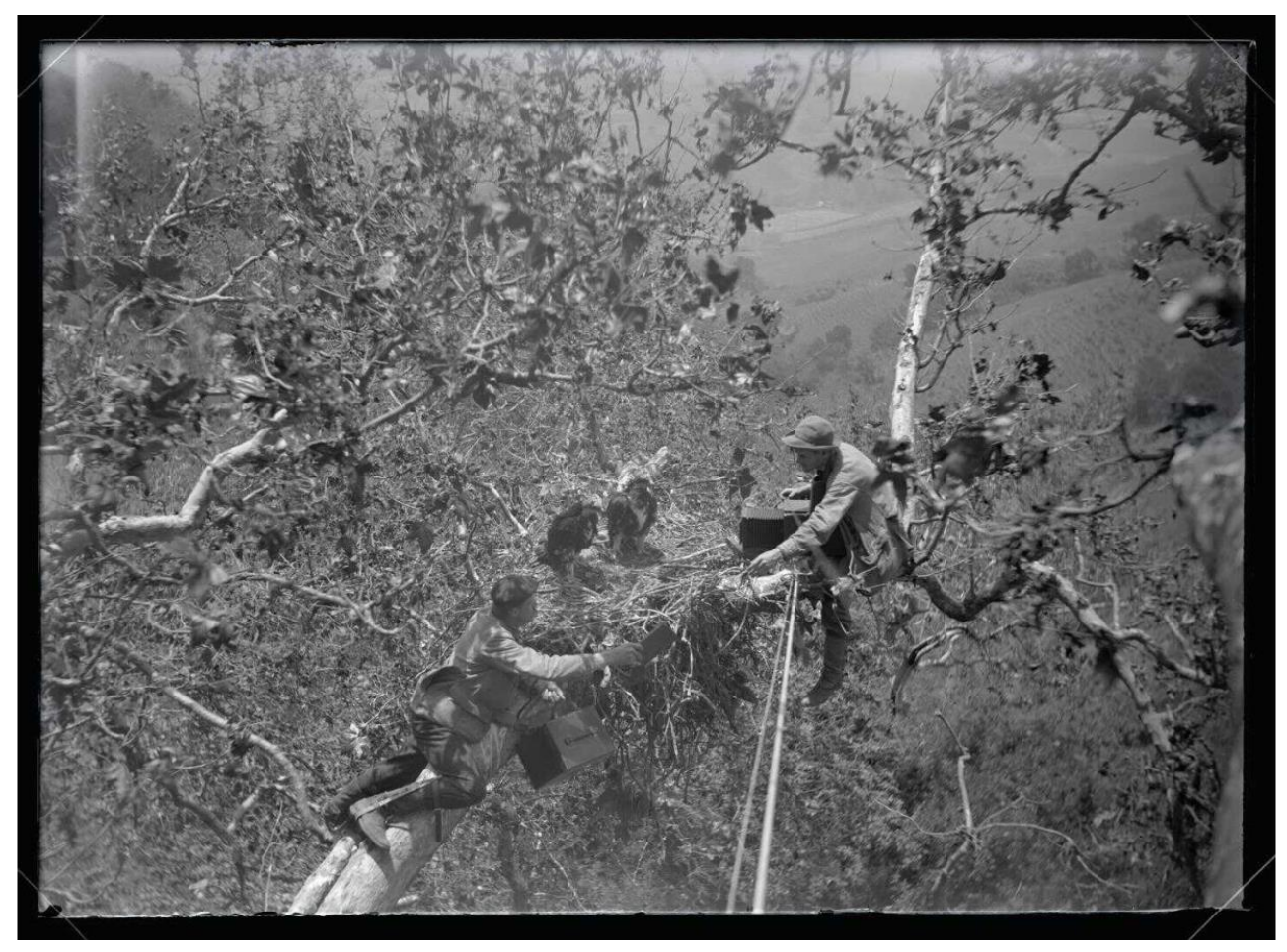

Figure 21. Bohlman passing Finley a glass plate with two Golden Eagles in their nest, 1904. Finley A441, William L. Finley Photograph Collection, OHS.

They nearly lost another camera when a rope broke as they were trying to haul it up; Finley was below and able to break its fall, but the camera was heavy enough to knock him over. They were surprised, and probably relieved, that the adult eagles did not try to defend their nest, but simply moved off when the photographers arrived. They 
attributed this to the growing encroachment of humans on their territory, but noted neither the adults nor the chicks seemed to welcome the attention of the photographers. ${ }^{2}$

Finley and Bohlman used bicycles on their way to take photographs of herons as well. To get to the heron rookery in the swampy part of South San Francisco Bay required crawling through a dense thicket of blackberry, nettles, and poison oak. There were also mosquitoes. They improvised a bug repellant of alcohol and salt, which they put on their faces, hands, and arms, and allowed to dry. Bohlman later wrote, "we both looked like a salt encrusted herring." The improvised repellent didn't work. ${ }^{3}$

Finley and Bohlman also photographed barn owls in the summer of 1904 near his grandparents' property in Santa Clara. Finley later used these photographs, along with some of screech owls and raptors, to illustrate several articles in which he argued for the economic benefit of birds of prey. ${ }^{4}$ The owls' nest was in an old pigeon box in the peak of the barn's roof. Finley and Bohlman climbed a ladder and then swung up from the rafters to the nest. They rigged up a space for the camera by nailing up a ladder to hold a board on which to set the camera. By taking off the back of the nest box, and setting it so it could be removed and reattached, they got a series of photographs of the barn owl chicks developing.

For the chapter on owls in American Birds, Finley chose a photograph of four eggs in a nest (Figure 22) and later pictures of the three surviving owlets lined up (Figure

\footnotetext{
${ }^{2}$ William L. Finley, “The Golden Eagles of Mission Ridge,” San Francisco Call, October 21, 1906.

${ }^{3}$ Mathewson, 48.

${ }^{4}$ William L. Finley, American Birds; Finley, "The Barn Owl and Its Economic Value," The Condor 8, no. 4 (1906): 83-88; William L. Finley, "Feathered Foragers," Sunset 19, no. 4 (August 1907): 382-387.
} 
23). At three weeks the baby owls were covered in white fluffy down with faces strangely resembling the bleached sheep skulls one associates with the desert West. When the owls were fully grown, they were grouped on tree branches, all looking at something away from the camera, nearly in profile. Their adult plumage has come in and so they appear to be wearing white masks, with the air of aloofness and distance enhanced by the way they are looking all three together away from the photographer. Finley also included a beautiful shot of one of the owls in flight and a lovely close portrait of one of the owls at about four weeks of age (Figure 24). The image is sharp and detailed, and the portrait sympathetic. The bird's soft dark eyes and tufts of white fluffy down contrast with its sharp beak, but most of all, the barn owl has a clearly defined face. It gazes at a slight angle away from the camera, giving the impression of perhaps thoughtful melancholy, with an appealing tilt of the head. It seems to have been one of Finley's favorites-he also used it for a retrospective article in the 1920s on his bird photography. ${ }^{5}$

\footnotetext{
${ }^{5}$ William L. Finley, "Hunting Birds with a Camera."
} 


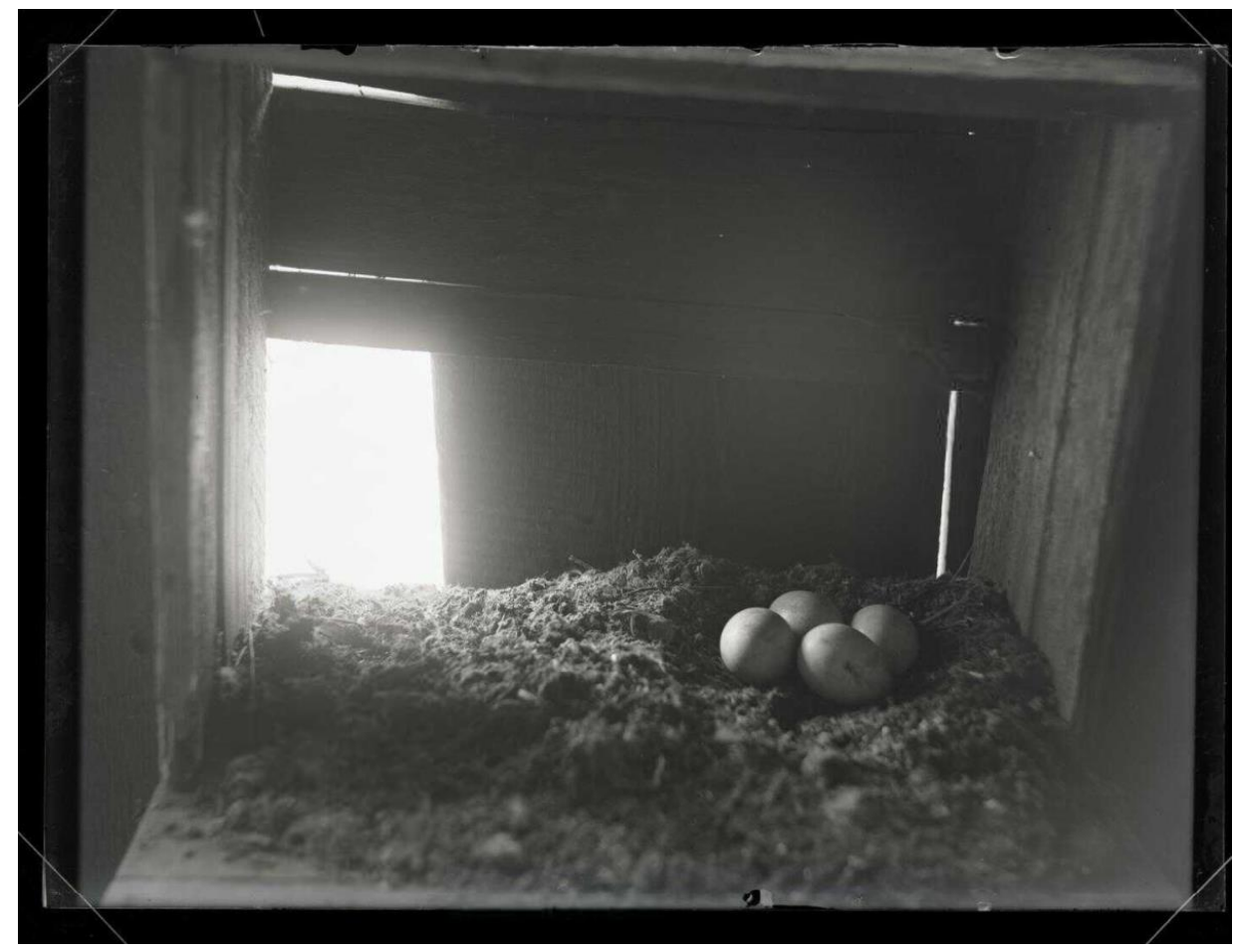

OHS.

Figure 22. Barn owl nest and eggs, 1904. FinleyA0558, William L. Finley Photograph Collection,

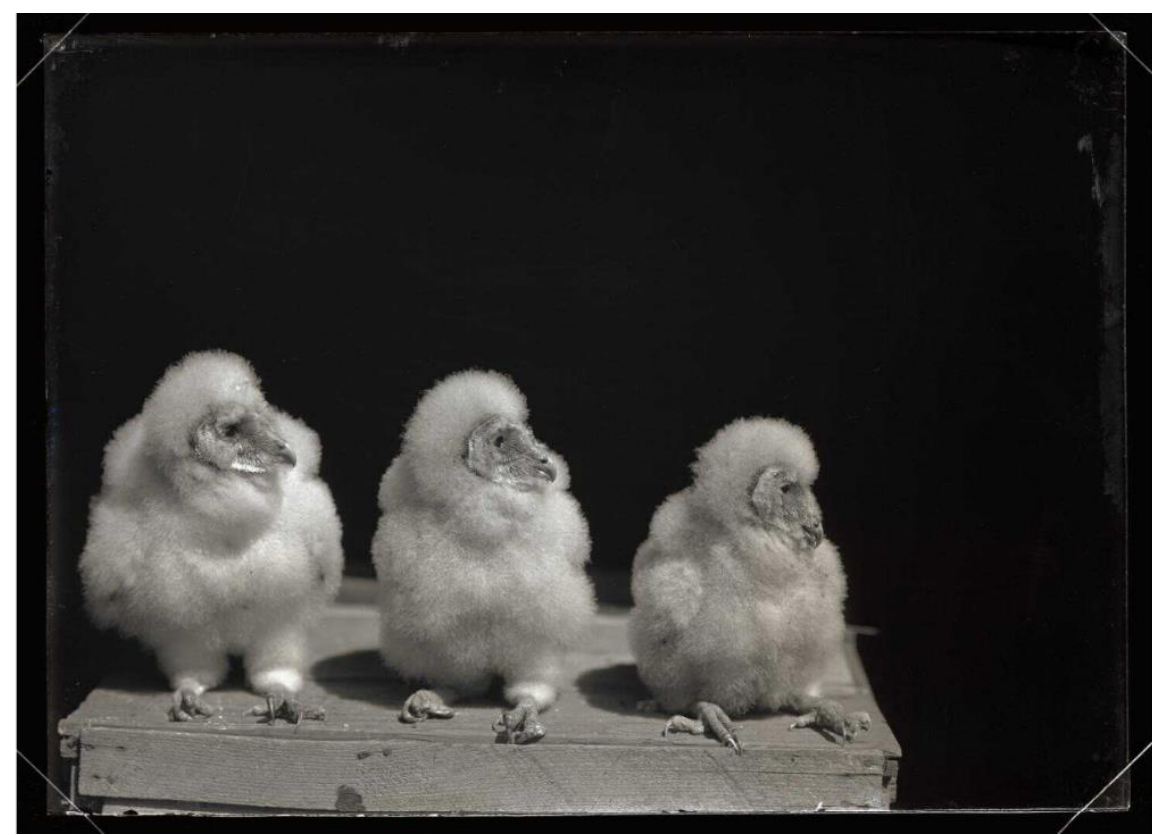

Figure 23. Barn owl chicks on a box, 1904. FinleyA0569, William L. Finley Photograph Collection, OHS. 


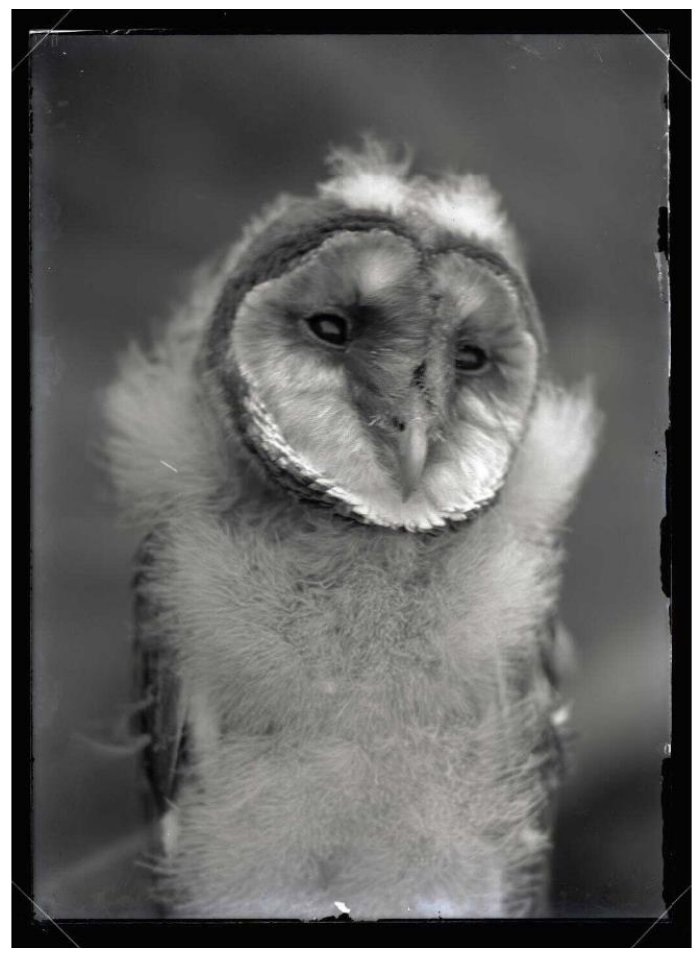

Figure 24. "Granny" barn owl portrait, 1904. FinleyA0589, William L. Finley Photograph Collection, OHS.

In 1905, after Finley had become a field representative for the National Audubon Society, he and Bohlman spent the summer on the border of Oregon and California. They visited what is now the Lower Klamath Wildlife Refuge and the Tule Lake National Wildlife Refuge to inspect conditions for National Audubon and take photographs. In their later report they explained they had focused on a few areas in order not to spend the summer constantly on the move, resulting in superficial impressions. ${ }^{6}$ The area they were evaluating for National Audubon was extensive. They had also realized they did their best photography when they immersed themselves in an area for an extended period.

6 “State Reports: Oregon,” Bird-Lore 7 (1905): 336-342. 
In late May of 1905, Finley and Bohlman set out from Ashland and crossed the Cascade Range on horseback. ${ }^{7}$ They brought camping gear, three cameras and about 700 glass plates for exposures. ${ }^{8}$ For much of the trip they traveled with a small boat, which they had to portage overland at several points. ${ }^{9}$ They traveled along the Klamath River following the edge of the Klamath marsh. Near Klamath Falls they took the Lost River to Tule Lake, just south of the Oregon-California border where they sought out a large grebe rookery that been reported. They did not find it, and at first saw few grebes if any, which Finley blamed on the market hunting of previous years. ${ }^{10}$ They did find cormorants and white pelicans, and, when talking to someone during a supply run, received a tip on where to look for grebes. They located the new grebe nesting ground, but it was smaller than the previously reported one. They also saw terns, stilts and avocets. They reported to Audubon they had found "the greatest rendezvous for Ducks and Teal we have ever seen" and that although the locals did not hunt during nesting season, in the fall there was a great deal of shooting by market hunters. ${ }^{11}$

At Lower Klamath Lake they found many nesting birds, including Caspian terns, great blue herons, cormorants, gulls, and white pelicans. The nests were not on shore, but on small islands made up of tule reeds in the lake. Finley and Bohlman also used these

\footnotetext{
${ }^{7}$ Finley to Grinnell, May 16, 1905, Folder-Finley, Box 7, Joseph Grinnell Papers, BANC MSS C-B 995, The Bancroft Library, University of California, Berkeley (hereafter Joseph Grinnell papers, BL); William L. Finley, "The Cruise of Two Camera Hunters," The Pacific Monthly, 23: 632-641.

${ }^{8}$ Finley to Grinnell, May 16, 1905 and July 17, 1905, Joseph Grinnell papers, BL.

${ }^{9}$ Finley, "The Cruise of Two Camera Hunters."

${ }^{10}$ Grebes have very soft feathers, especially on the breast, so their skins were popular for use in ladies' muffs and collars, as well as hats. Sometimes birds were killed and stripped of the down at the breast, and the rest of the carcass left behind.

11 “State Reports: Oregon,” Bird-Lore (1905): 336-342.
} 
islands to make camp, which was not very comfortable. There were more grebes nesting on Lower Klamath Lake than on Tule Lake, and the men were able to watch a couple of baby grebes fight their way out of their eggs, and get photographs of the newly hatched grebe chicks. The grebes were tough subjects to photograph; they dove quickly and then popped up again in unexpected places. Although Finley and Bohlman spent two days hiding in the reeds, they only got a few good exposures. ${ }^{12}$

Finley twice expressed his regrets to Joseph Grinnell that he was not able to collect specimens for him because of being so busy with the camera work, but he and Bohlman did document the process of preparing Western Grebe bird skins. ${ }^{13}$ In the series, an unidentified person prepares the skin of the dead grebe by cutting off the wings, splitting the skin and stretching it on a board (Figures 25, 26, 27, 28). ${ }^{14}$

12 William L. Finley, “The Grebes of Southern Oregon,” The Condor 9, no. 4 (1907): 97-101.

${ }^{13}$ Finley to Grinnell, June 22, 1905 and July 17, 1905, Joseph Grinnell papers, BL.

14 The negatives of the photographs documenting the skinning process are noted 1905 but who marked them and when is unknown. In 1908 when Finley and Bohlman returned to Southern Oregon, they did hire a collector, Henry Peck, to come along with them. It is possible the photographs were taken during the later trip. 


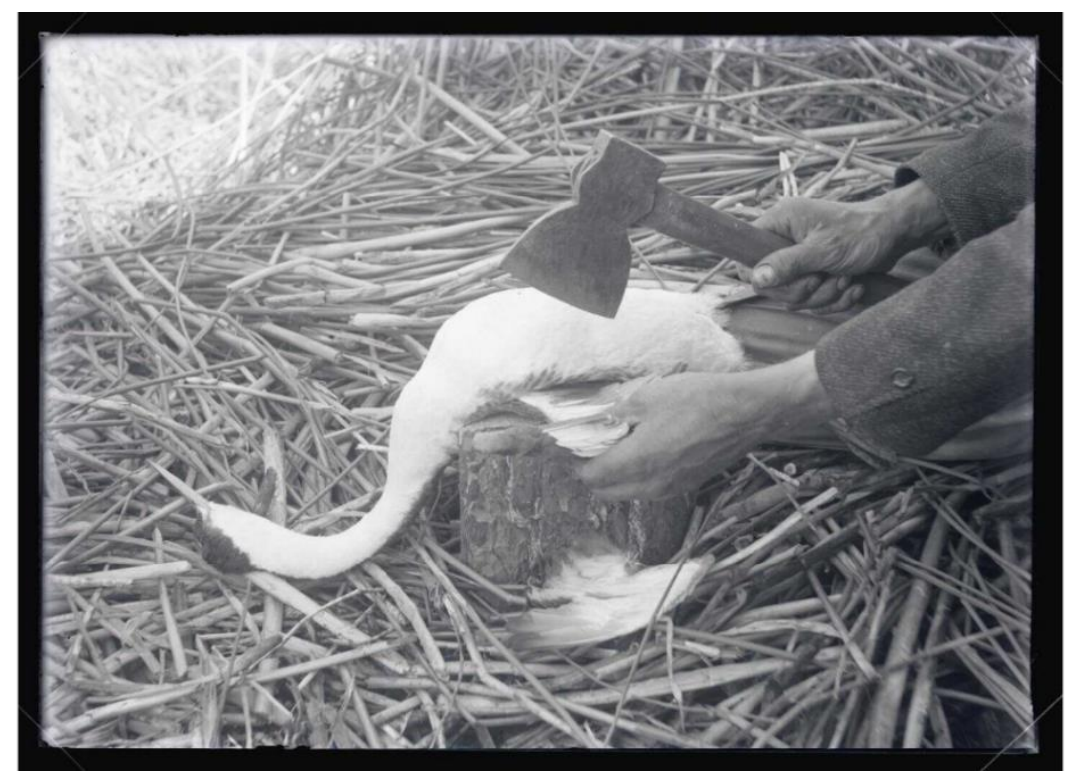

Figure 25. Western grebe skinning, cutting off wings to prepare bird skin specimen, 1905. FinleyA1691, William L. Finley Photograph Collection, OHS.

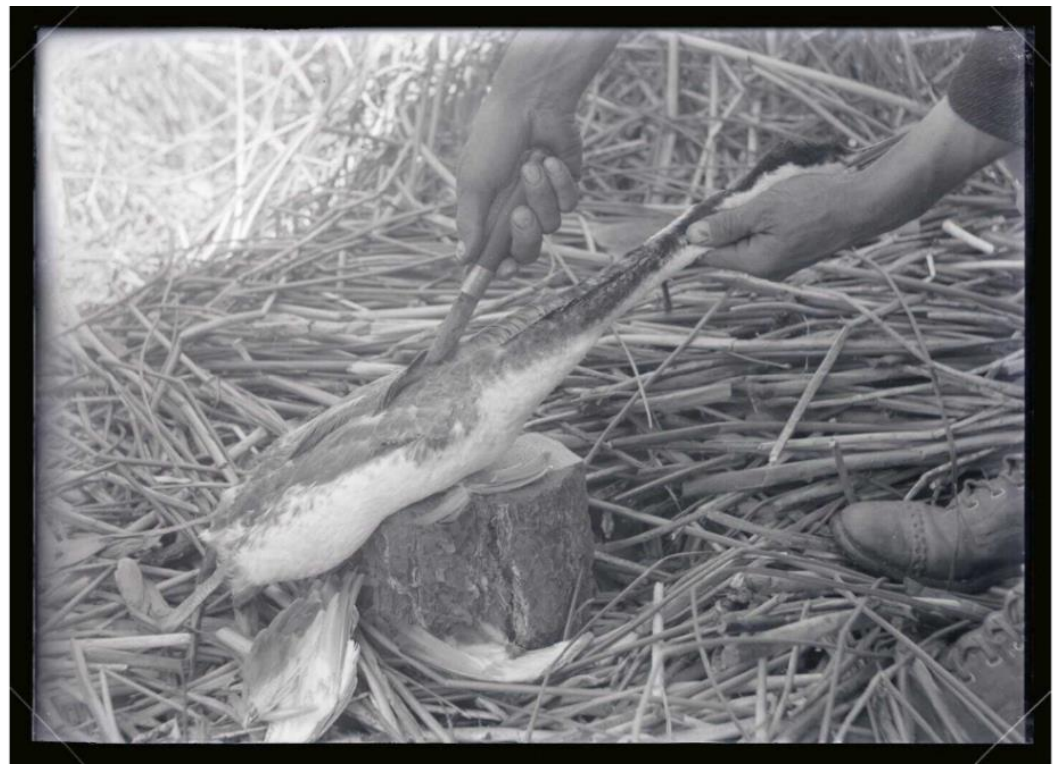

Figure 26. Western grebe skinning, opening the skin down the back, 1905. FinleyA1692, William L. Finley Photograph Collection, OHS. 


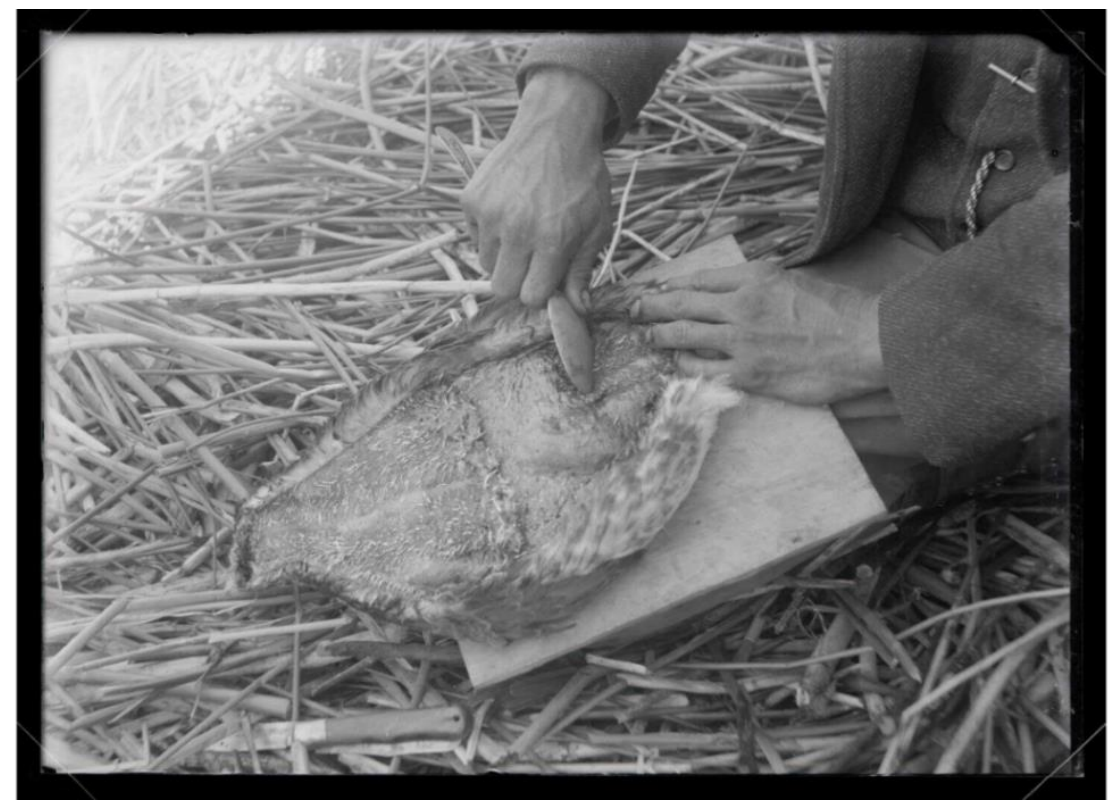

Figure 27. Western grebe skinning, scraping the skin, 1905. FinleyA1695, William L. Finley Photograph Collection, OHS.

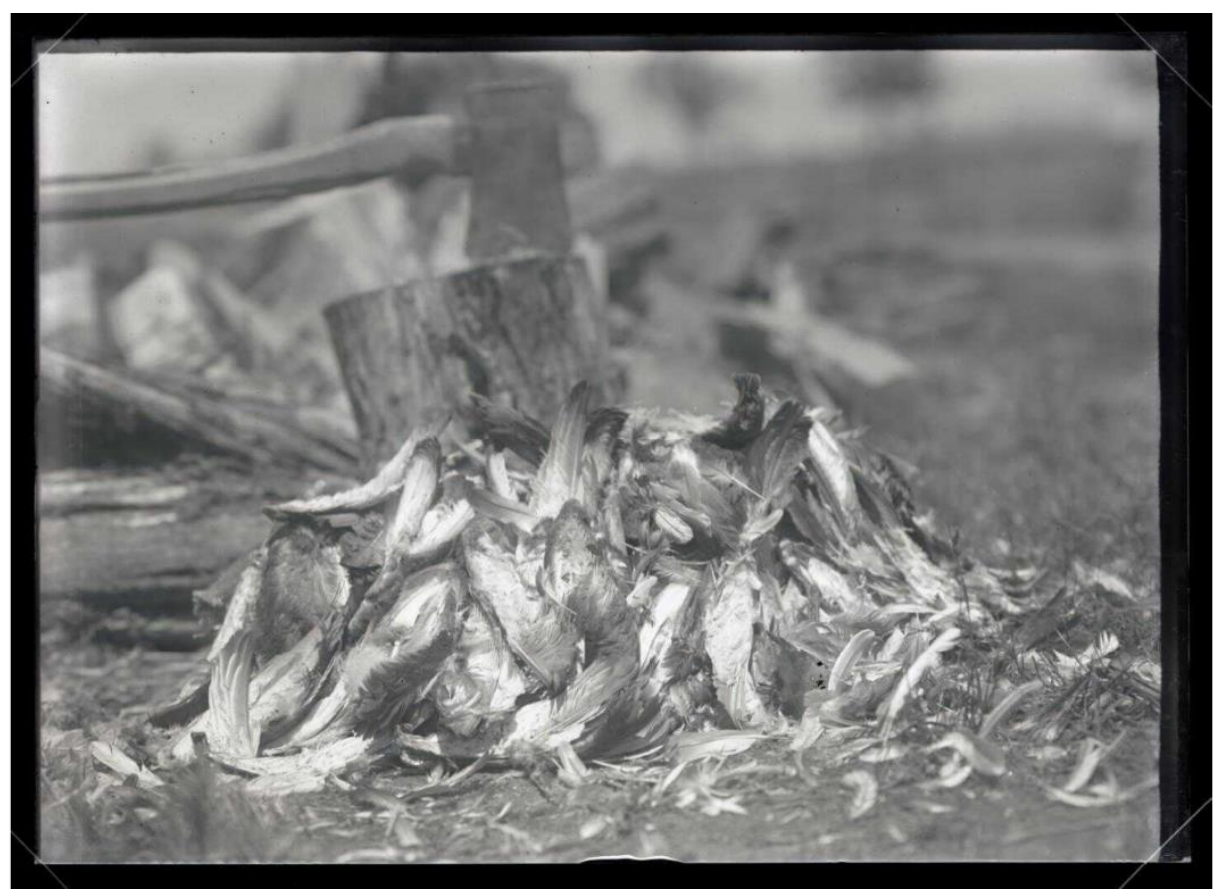

Figure 28. Western grebe skinning, wings at the chopping block, 1905. FinleyA1696, William L. Finley Photograph Collection, OHS. 
Finley and Bohlman were impressed with the sheer numbers of gulls they found and worked to get some clear pictures of the hundreds flying overhead. The camera had to be set up and focused, waiting for the birds to come into view. Getting a clear shot required excellent timing on the part of the photographer. They also wanted photographs of the nesting ground but found that when they went near the nests "the whole colony of birds went frantic" making photography impossible. They created a blind with an old umbrella and green canvas, cutting small holes to aim the camera through. Then at a distance they hid underneath it with their cameras and spent nearly an hour moving slowly toward the edge of the nesting ground until they were close enough to watch and take pictures of gulls. It was very uncomfortable — hot, and surrounded by the smell of dead fish. Also, the blind did not hide them from the mosquitoes and flies. ${ }^{15}$

Finley and Bohlman also found white pelican rookeries and used the blind to get close (Figure 29). Finley reported that without it young pelicans when approached would "vomit up fish" and then push to get away from the men into the middle of the massed group of young birds. They did get some excellent photographs, including shots of themselves interacting with the birds (Figure 30, Figure 33), a close-up of a young pelican (Figure 31), and a shot of a pelican taking off from the surface of the lake (Figure 32). ${ }^{16}$

\footnotetext{
${ }^{15}$ William L. Finley, "Among the Gulls on Klamath Lake," The Condor 9, no. 1 (1907): 12-16.

${ }^{16}$ William L. Finley, "Among the Pelicans," The Condor 9, no. 2 (1907): 35-41.
} 


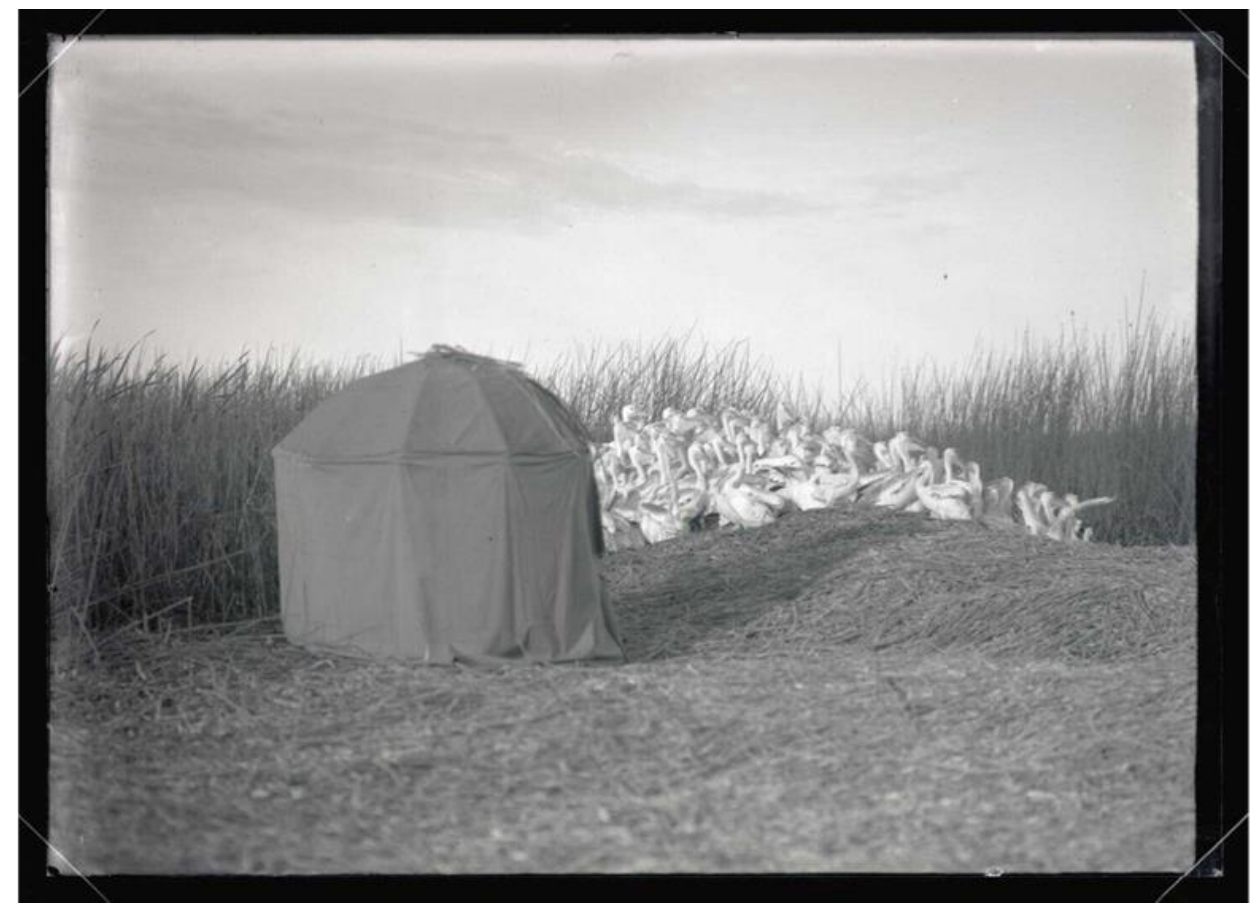

Figure 29. Pelicans investigate the umbrella blind, 1905. FinleyA1793, William L. Finley Photograph Collection, OHS.

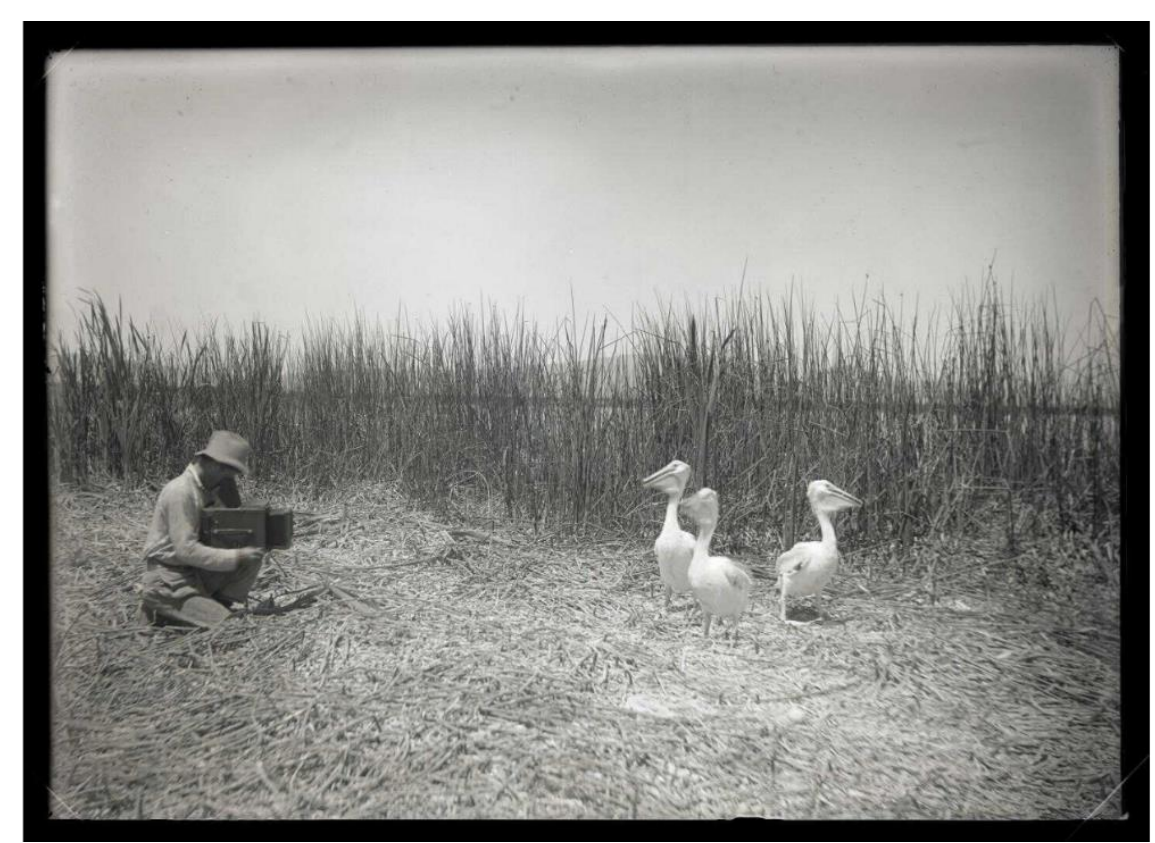

Figure 30. Finley photographing three young pelicans, 1905. Finley A1795, William L. Finley Photograph Collection, OHS. 


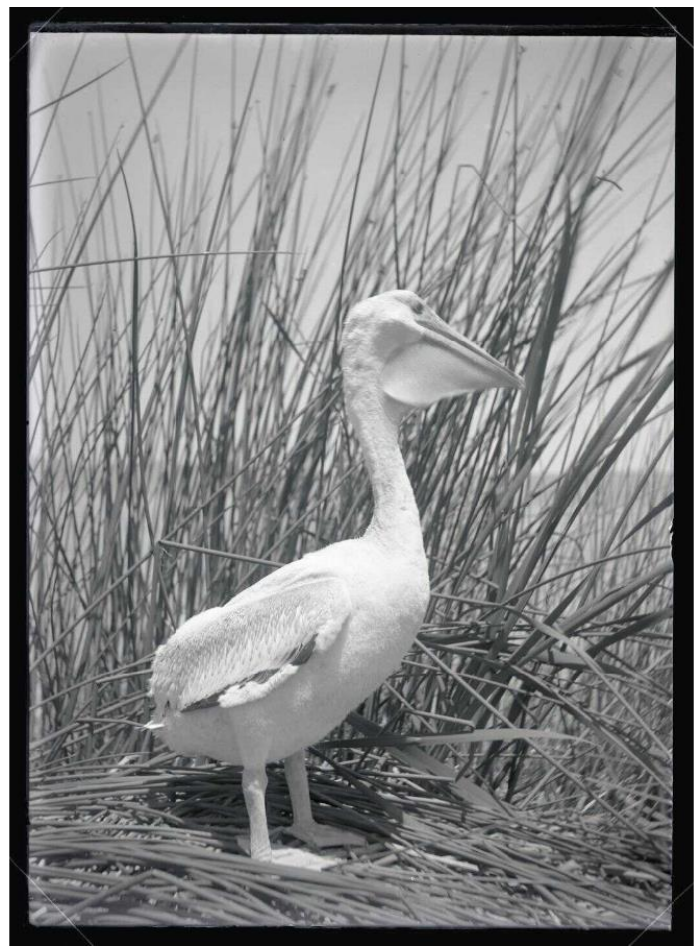

Figure 31. Young pelican, 1905. Finley A1778, William L. Finley Photograph Collection, OHS.

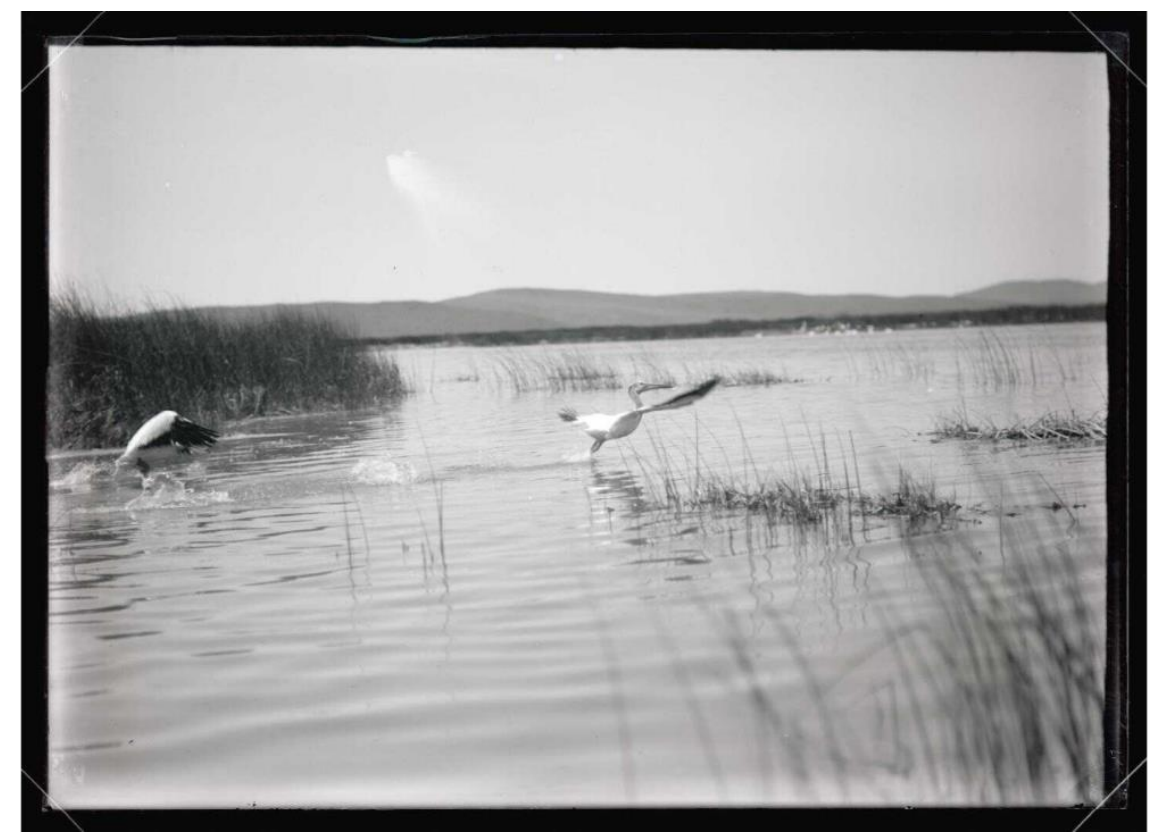

Figure 32. Pelican rising from the water, 1905. FinleyA1814, William L. Finley Photograph Collection, OHS. 


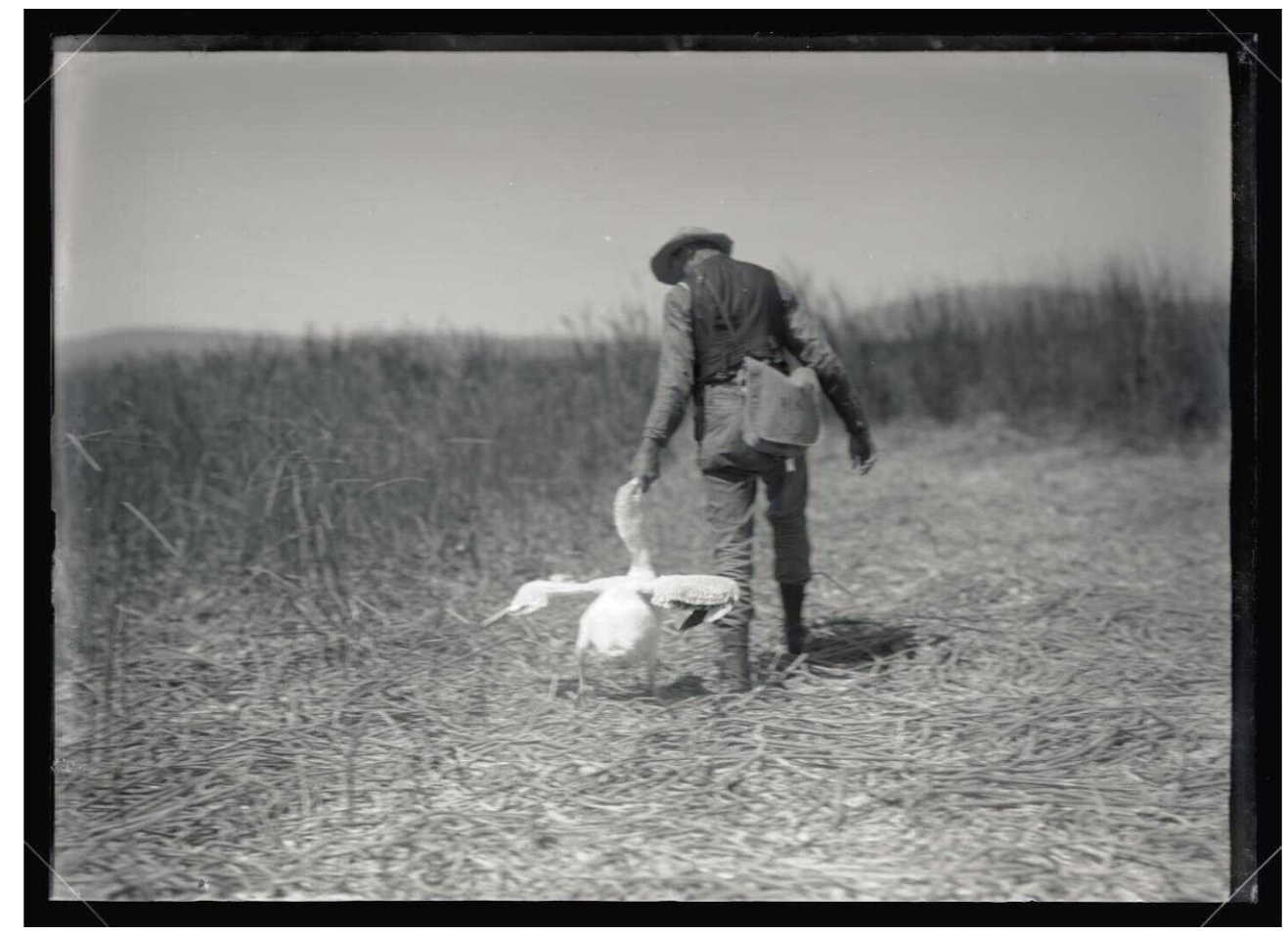

Figure 33. Bohlman walking with pelican, 1905. FinleyA1796, William L. Finley Photographs Collection, OHS.

While still in Southern Oregon Finley was excited to receive a letter from Joseph Grinnell, who wrote he had spotted a young condor in Southern California. Upon his return to Portland in summer 1905 Finley replied, reminding Grinnell that he and Bohlman had been eager to capture a life series of condors, and that if Grinnell had found a nesting pair it could be their opportunity. "I would like to visit the nest and get pictures of the egg and then wait til it hatches and picture the youngster from the egg to full feathers, it would make a cracking series and one of value."17

\footnotetext{
${ }^{17}$ Finley to Grinnell, July 17, 1905, Joseph Grinnell papers, BL.
} 
In December 1905 Finley again wrote Grinnell from Portland to say he was "very anxious to land that Condor series" as well as photographs of road runners, and to get out to the Channel Islands off of Southern California to photograph eagles. ${ }^{18}$ The day after Christmas he sent Grinnell yet another letter saying he would come to California in early February. He wrote that he and Bohlman, who would come to California in the spring, were focused on obtaining life series of their subjects. Finley wanted advice on locating desert birds, such as the road runner and the cactus wren, and details on how and when to go to the Channel Islands in search of nesting eagles. ${ }^{19}$ About the condors Finley wrote that he and Bohlman would "spare no efforts to land them." He asked Grinnell to keep an eye on the nesting pair Grinnell had found, and agreed with Grinnell's apparent advice that it would be better to wait to visit the nest until the egg were close to hatching, to lessen the possibility the adult birds might abandon the nest. ${ }^{20}$ In response, Grinnell seems to have warned Finley that although he knew the general area in the canyon, finding the exact location of the nest would take some effort. ${ }^{21}$ Finley asked Grinnell to try to keep the possible location of the condors quiet, for fear of a collector finding the spot. $^{22}$

In February of 1906, Finley and Irene married in a small ceremony at her parents' home in Santa Monica. On March 10, Finley, Grinnell and Walter P. Taylor, a student of

\footnotetext{
${ }^{18}$ Finley to Grinnell, Dec. 15, 1905, Joseph Grinnell papers, BL.

${ }^{19}$ Finley to Grinnell, Dec. 26, 1905, Joseph Grinnell papers, BL.

${ }^{20}$ Ibid.

${ }^{21}$ Finley to Grinnell, Jan. 30, 1906, Joseph Grinnell papers, BL.

${ }^{22}$ Finley to Grinnell, July 17, 1905 and Jan 30, 1906, Joseph Grinnell papers, BL.
} 
Grinnell's, set out on foot from Pasadena to walk up Eaton Canyon to where Grinnell had seen the condors. ${ }^{23}$ Bohlman had not yet arrived in California.

Finley was struck by the change in terrain, noting the contrast between the cultivated gardens of Pasadena's residential neighborhoods, the irrigated fields and vineyards they passed, and the condors' domain, "the roughest, wildest place without an indication of human habitation." The birds were nowhere to be seen. They searched for hours, shouting in hopes the disturbance would surprise a bird into revealing itself. That didn't work, so Finley fired a few shots with an old revolver. The noise startled a condor into the air, but they lost her on the canyon cliff. Shooting the gun again caused the bird to rise into the air once more, giving away the nest's location - in a small cave created by a boulder against the hillside. The bird flew off and the men climbed up to look. They discovered they had had the amazing good fortune to find a nest with one egg (Figure $34) .^{24}$

Finley hoped to get back before the egg hatched, but for a week it rained hard, and when he went back with cameras, the canyon was flooding and he couldn't reach the nest. The rain persisted for two weeks, to Finley's dismay. "I never saw such weather even in Oregon!"25

\footnotetext{
${ }^{23}$ Taylor, then eighteen years old and a student of Grinnell's at Throop Polytechnic Institute (later Caltech), would go on to a distinguished career as a biologist. He followed Grinnell to UC Berkeley, earning his doctorate in 1914. He worked as a biologist for the Biological Survey and U.S. Fish \& Wildlife, as well as holding academic appointments at several universities in the American Southwest.

${ }^{24}$ William L. Finley, "Life History of the California Condor. Part I. Finding a Condor's Nest," The Condor 8, no. 6 (1906): 135-42. Finley referred to the place as "Carnello Canyon" in this and other published pieces about finding the nest to hide the actual specific location.

${ }^{25}$ Finley to Grinnell, Mar. 21, 1906, Joseph Grinnell papers, BL.
} 


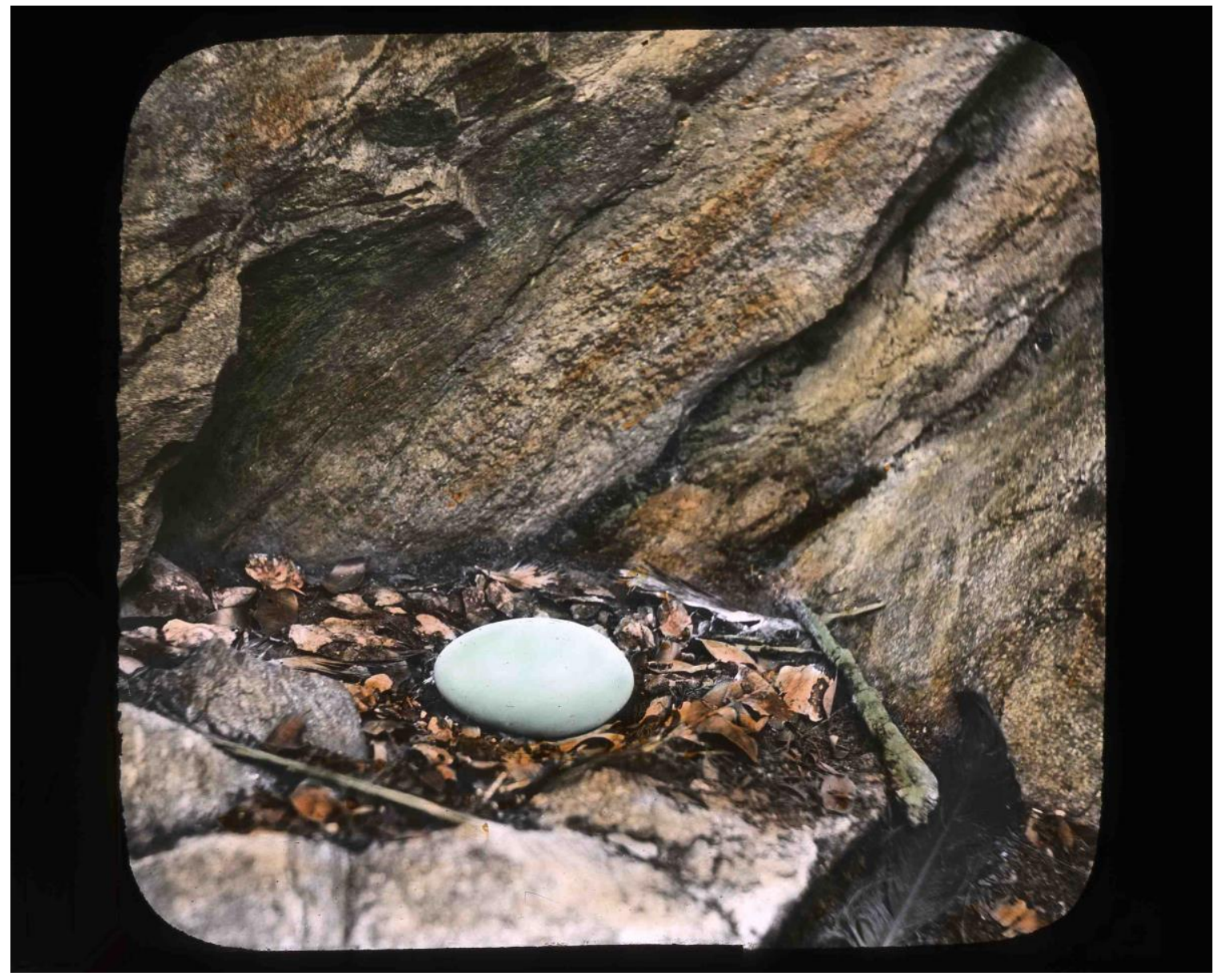

Figure 34. Condor egg on a ledge nest. Lantern slide. Audubon Society of Portland, United States Fish and Wildlife Digital Library. https://digitalmedia.fws.gov

On March 23, Finley tried again. Grinnell was not able to go, and Bohlman was still in Oregon, so Finley’s wife Irene came along to assist with photography. Landslides had washed out sections of the trail. The Finleys had to leave some of their equipment along the route and use rope to climb up to the nest, grabbing roots and bushes for support as they went. When they got close they could see the female condor in the cave; Finley climbed up to where he could look down into it and discovered a new chick, probably not more than a day old, in the nest (Figure 35). 


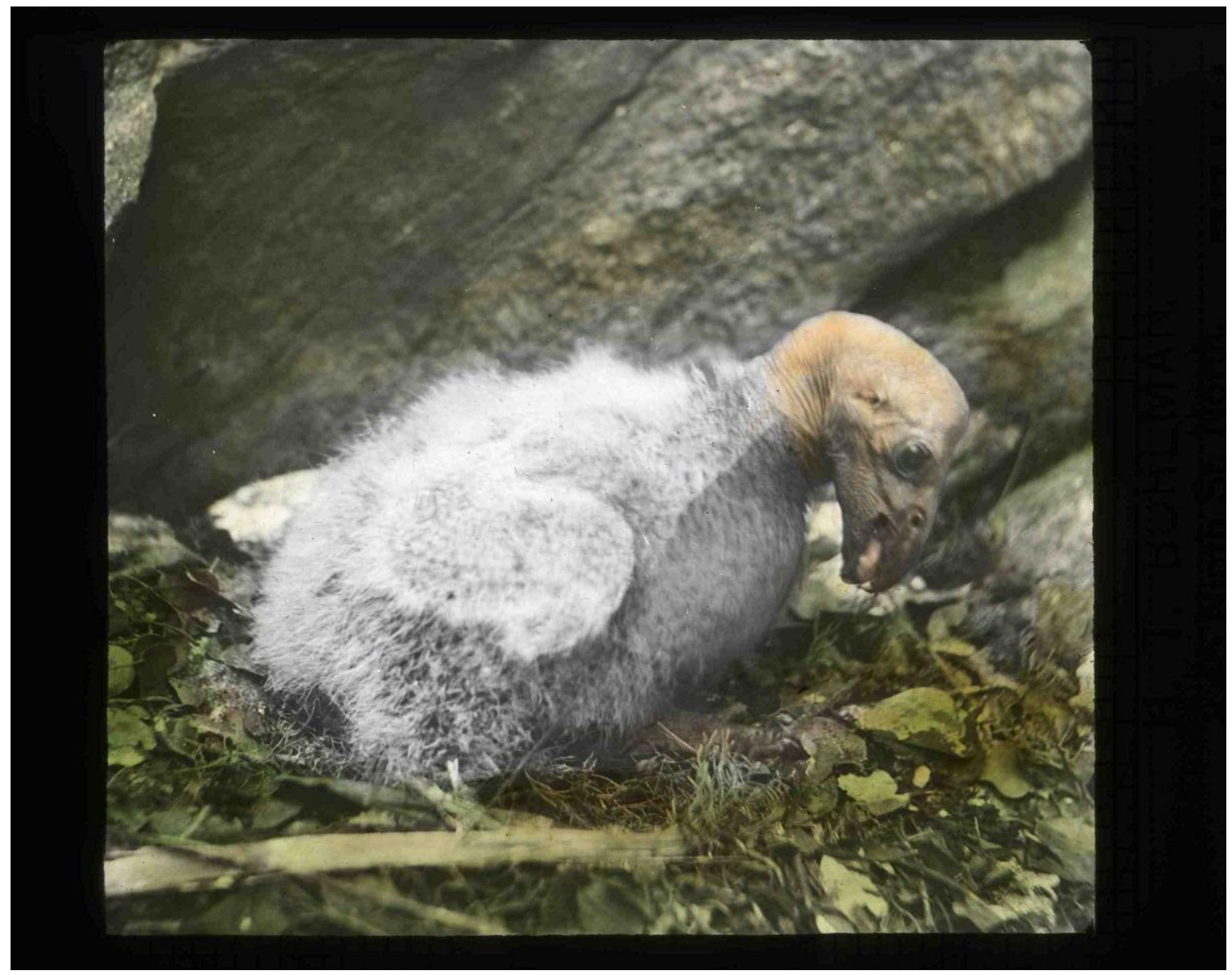

Figure 35. The condor chick newly hatched, 1906. Lantern slide. Audubon Society of Portland, United States Fish and Wildlife Digital Library. https://digitalmedia.fws.gov

The condor mother refused to leave, and tried to cover her chick from view. Although nervous about dealing with such a large bird while he precariously balanced on a narrow ledge, Finley was determined to get a shot, so he used a short stick to nudge the mother away, then reached in and took the chick. It was a dark afternoon, so Finley needed a slow exposure, and the baby condor would not hold still. Finley tried to work quickly, but after five exposures he suddenly realized the chick was getting cold, and put it back in the nest. The mother ignored it. Finley tried to nudge her back toward her baby, 
which by now was lying very still. They pulled the chick out again and Irene held him to warm him up. The male condor arrived, and was circling above the Finleys as they crouched on the rocks. Finley stood up holding his tripod high to ward off the big bird. When the baby bird began moving again, they put him back in the nest, and much to Finley's relief, the mother drew him toward her. ${ }^{26}$

Of the five exposures, two were good. Years later Finley wrote in Wild Animal Pets that he sent these to Bohlman. Bohlman telegraphed that he would take three months off work, and come to California. Since Finley had written the previous summer to Grinnell about the field work he and Bohlman planned in California for the spring of 1906 this was possibly a bit of added drama on Finley’s part, although Bohlman was more skeptical than Finley about the likelihood of success in getting the condor shots. ${ }^{27}$ Finley had felt sure they could find a nesting pair in the mountains above Pasadena; Bohlman had told Finley "it was "dollars to doughnuts"” even if Finley found a nest that they "would have to dangle at the end of a rope to see it." 28

Bohlman arrived in Southern California in early April 1906, bringing more gear. Finley and Bohlman made at least seven trips out to the nest to photograph the young condor in various stages of development, as well as observe and photograph the behavior

\footnotetext{
${ }^{26}$ William L. Finley, "Life History of the California Condor. Part I. Finding a Condor's Nest”; William L. Finley, "Home life of the California Condor," Century Illustrated 75 (1908):370-380.

${ }^{27}$ William L. Finley and Irene Barnhart Finley, Wild Animal Pets, C. Scribner's Sons, 1928, 159-160; Finley to Grinnell, July 17, 1905, Joseph Grinnell papers, BL.

${ }^{28}$ Finley, "Home Life of a California Condor."
} 
of the adult pair and the group as a family (Figure 36), a valuable record given the birds' scarcity. ${ }^{29}$

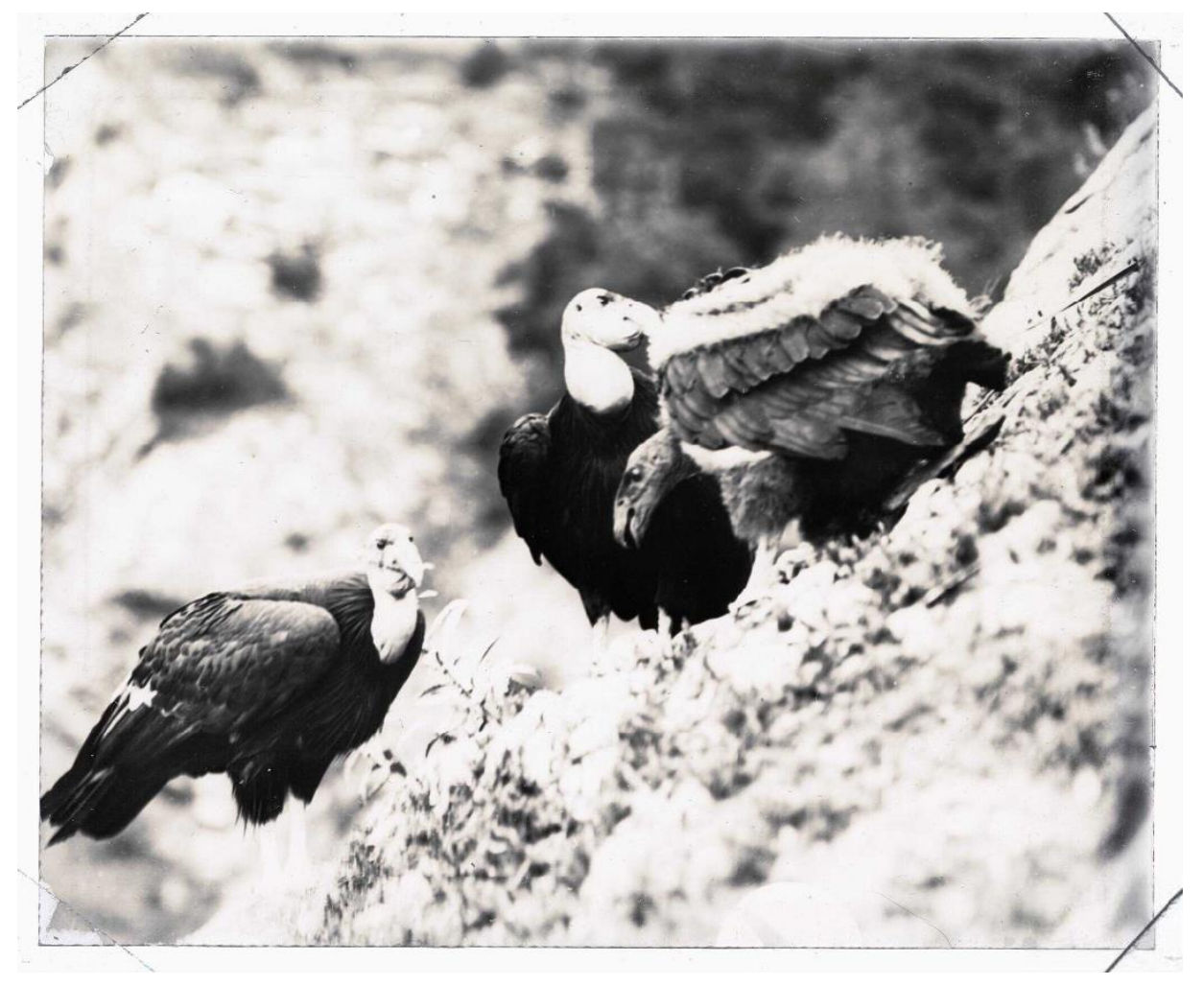

Figure 36. The California condor pair with chick. Finley C0158, William L. Finley Photographs Collection, OHS.

The weather continued to be uncooperative, making their work difficult. Although Finley was pleased with an April photo of one of the adult birds in flight, he noted they had to use longer exposures because of the cloudy weather, so early photos of the young condor were not clear, but "showed motion."30

\footnotetext{
${ }^{29}$ Finley refers to eight visits, and writes about a visit in early June. Finley did not in fact make the June trip himself, as he was recovering from a horseback riding accident on the island of San Clemente.

${ }^{30}$ Finley to Grinnell, April 13, 1906, Joseph Grinnell papers, BL.
} 
While in Southern California Finley had been in touch with other Cooper Club members H. J. Leland and John Eugene Law about potential locations for photography, and he and Bohlman went after more than just condors that spring and summer, but the condor series was their greatest success. ${ }^{31}$ Finley later referred to a summer spent unsuccessfully hunting for white cranes (probably referring to egrets) in Southern California with Bohlman. ${ }^{32}$ They took a number of photographs of gulls on the beach near Santa Monica. They took a trip to the Channel Islands to look for eagles, but it turned out to be something of a disaster.

In late May 1906 Finley and Bohlman were out on San Clemente Island looking for eagle and osprey nests when Finley was thrown from his horse and injured. They had traveled by launch from Catalina Island to San Clemente, where they had arranged to camp with a group of sheepherders. The sheepherders brought in three horses for the photographers, two to ride and one to serve as a pack animal. Finley's horse was, as he put it, "a son-of-a-gun, awful hard \& bold." 33 Since Finley's horse wanted to run, Bohlman rode with the pack horse while Finley went out ahead to scout. Finley spotted an eagles' nest and was heading back to Bohlman when the horse bolted, and then fell, sending Finley flying over its head. Finley reported to Grinnell, "I landed square on my face." His jaw was broken in two places, his lip cut through, along with broken teeth, cuts on his tongue, and a sprained wrist. He had to ride several miles back to camp, and then

\footnotetext{
${ }^{31}$ Finley to Grinnell, April 13, 1906, Joseph Grinnell papers, BL. Finley likely refers to active Cooper Club members H.J. Leland and J. Eugene Law.

${ }^{32}$ William. L. Finley, "The Trail of the Plume Hunter," Atlantic Monthly, 106 (1910):373-379.

${ }^{33}$ Finley to Grinnell, June 3, 1906, Joseph Grinnell papers, BL.
} 
go by launch back in bad weather to Avalon on Catalina Island, where they arrived after midnight. Bohlman went to find a doctor who set the bones temporarily and bandaged Finley up. The next morning they took the boat from Avalon to Los Angeles, and Finley had the bones reset and his tongue and lip stitched up at the hospital, where he stayed for a week. He was only able to take liquids for longer than that, but observed he was lucky not to have broken his neck. ${ }^{34}$

The accident essentially ended Finley's field work for the season. Bohlman went on his own to Eaton Canyon on June 11 and 12 to add to their series of the young condor's development. The photos came out well, but Finley and Bohlman were surprised at how slowly the bird grew. They had hoped to capture a complete sequence from egg to full feathers, but when Bohlman visited the bird it was still downy at about three months of age. Finley also wanted to be able to visit the birds at least one last time as he had become quite attached to them, so he and Bohlman pushed back a week their planned return to Portland. They realized the condor chick was unlikely to be fully fledged until August, which presented a problem as they had wanted a full series of the bird's development. ${ }^{35}$

Throughout, Finley worried collectors would find the condors' location. Condors were so rare and therefore in demand that he was even cautious in responding to a request for information about condors from Frank Chapman of the American Museum of Natural

\footnotetext{
${ }^{34}$ Finley to Grinnell, June 3, 1906, Joseph Grinnell papers, BL.

${ }^{35}$ Finley to Grinnell, June 22, 1906, Joseph Grinnell papers, BL.
} 
History, although Chapman strongly favored bird protection. ${ }^{36}$ Chapman was meeting with California artist, Charles J. Hittell who painted backgrounds for Chapman's taxidermy dioramas for the museum. ${ }^{37}$ Although Chapman did not ask directly for a physical specimen, Finley guessed Chapman would pay well for a condor. He admitted to Chapman he was working on a condor series but told Chapman he could only give him photographs. ${ }^{38}$

Finley and Bohlman began to think about taking the young bird with them when they left. They seem to have been troubled in equal parts by the realization the youngster would not be fully fledged when they left California, and fear that the bird would be shot by a collector. Although they also worried about the loss to the adult condors, who Finley noted were "very devoted" parents, they started thinking about the logistics of bringing the young bird with them to Oregon, such as whether taking it alive would be legal, if a permit would be needed, and how to make sure the bird made the trip safely. ${ }^{39}$

In July Bohlman and the Finleys returned to Portland. Finley and Irene settled into a tent on their land at Jennings Lodge, on the Willamette River south of Portland, while their house was being built. Finley wrote Grinnell that they had decided after all "to kidnap the young Condor" which they had named General. "He weighed 15 pounds and

\footnotetext{
${ }^{36}$ Chapman, an early Audubon leader, began Bird-Lore, which would later become Audubon Magazine. He started the Christmas Bird Count in 1900. An alternative to the holiday tradition of shooting as many birds as possible, the $\mathrm{CBC}$ has evolved into perhaps the world's largest and longest running citizen science effort. Chapman also notably conducted a personal count of dead birds on ladies' hats while walking through Manhattan. Like Finley, he was a photographer and self-taught naturalist.

${ }^{37}$ Also known as Carlos Hittell.

${ }^{38}$ Finley to Grinnell, June 22, 1906, Joseph Grinnell papers, BL.

${ }^{39}$ Ibid.
} 
we packed him out in a bag and shipped him to Portland by express." ${ }^{40}$ Another Cooper Club member, W. Lee Chambers, had had a permit they had been able to use for shipping the bird. ${ }^{41}$ Finley had worried he would not be up to the trip up the canyon to collect the young condor, as he had lost weight on the liquid diet and was weak after his accident. He and Bohlman considered asking Chambers to help but were reluctant to reveal the exact nesting location to anyone else. In the end Finley managed the trip fairly well. ${ }^{42}$ Although Finley regretted that he and Bohlman had not gotten any shots of the adult birds feeding the young one, and was bothered by the thought they had distressed the older birds, he wrote Grinnell that General made "a great pet." The bird seemed to be in good health and liked to have his head rubbed. Immediately after their arrival in Portland, General lived in Bohlman's backyard, and then they moved him to the Finleys' property on the Willamette River where Finley and Irene were camped for the summer (Figure 37$).{ }^{43}$ By mid-August the bird was not yet flying, although it would jump eight to 10 feet along the ground, wings flapping. He was curious, playful, and seemed to enjoy interacting with people (Figure 38, Figure 39). Finley reported General followed him around and pulled the buttons on his coat. ${ }^{44}$

${ }^{40}$ Finley to Grinnell, Aug. 15, 1906, Joseph Grinnell papers, BL.

${ }^{41}$ Finley to Grinnell, Aug.16, 1906, Joseph Grinnell papers, BL.

${ }^{42}$ Finley to Grinnell, Sept. 13, 1906, Joseph Grinnell papers, BL.

${ }^{43}$ Finley to Grinnell, Aug. 15, 1906, Joseph Grinnell papers, BL.

${ }^{44}$ Finley to Grinnell, Aug. 16, 1906, Joseph Grinnell papers, BL. 


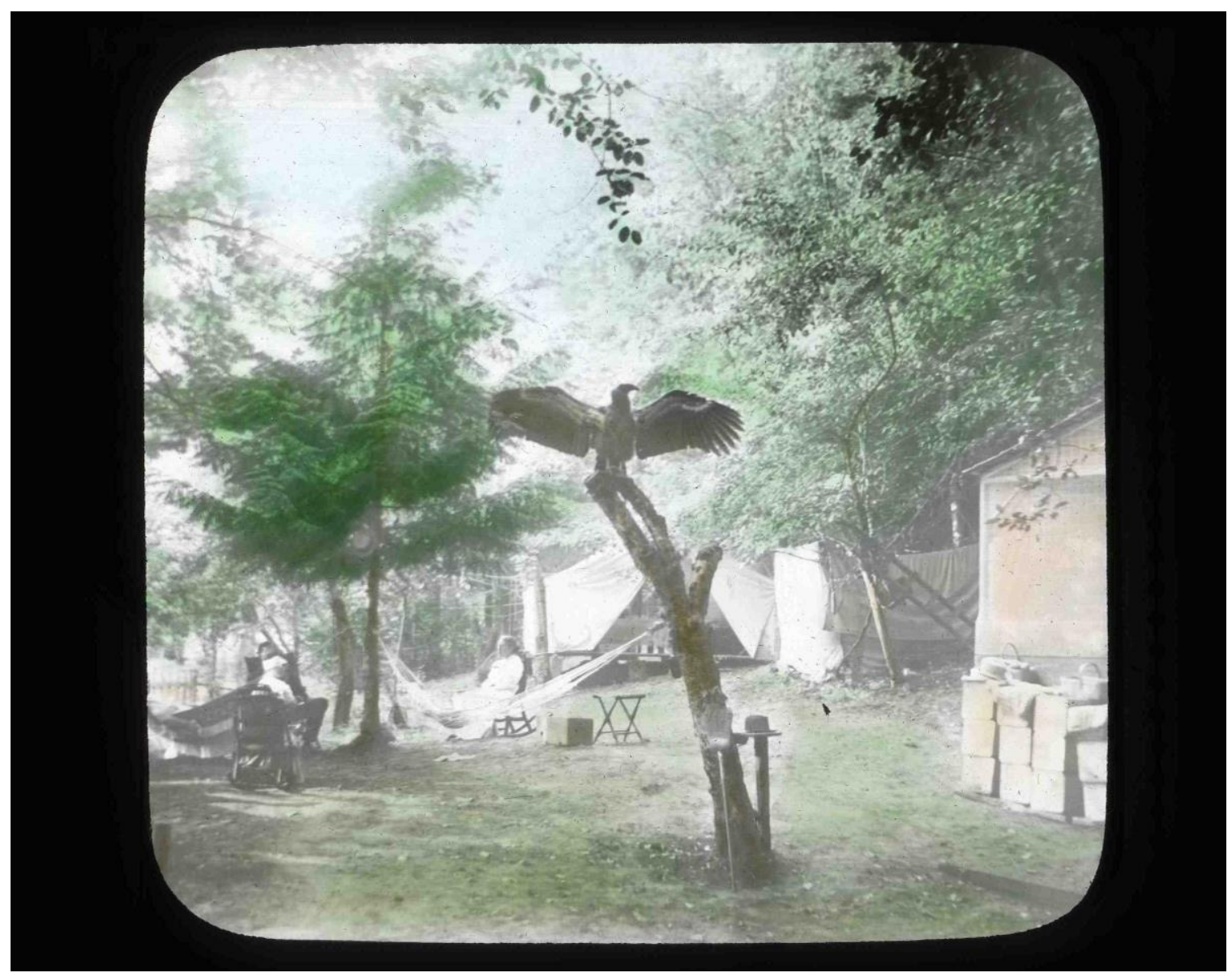

Figure 37. The condor "General" in camp at the Finleys' property at Jennings Lodge, south of Portland, 1906. Lantern slide. Audubon Society of Portland, United States Fish and Wildlife Digital Library. https://digitalmedia.fws.gov 


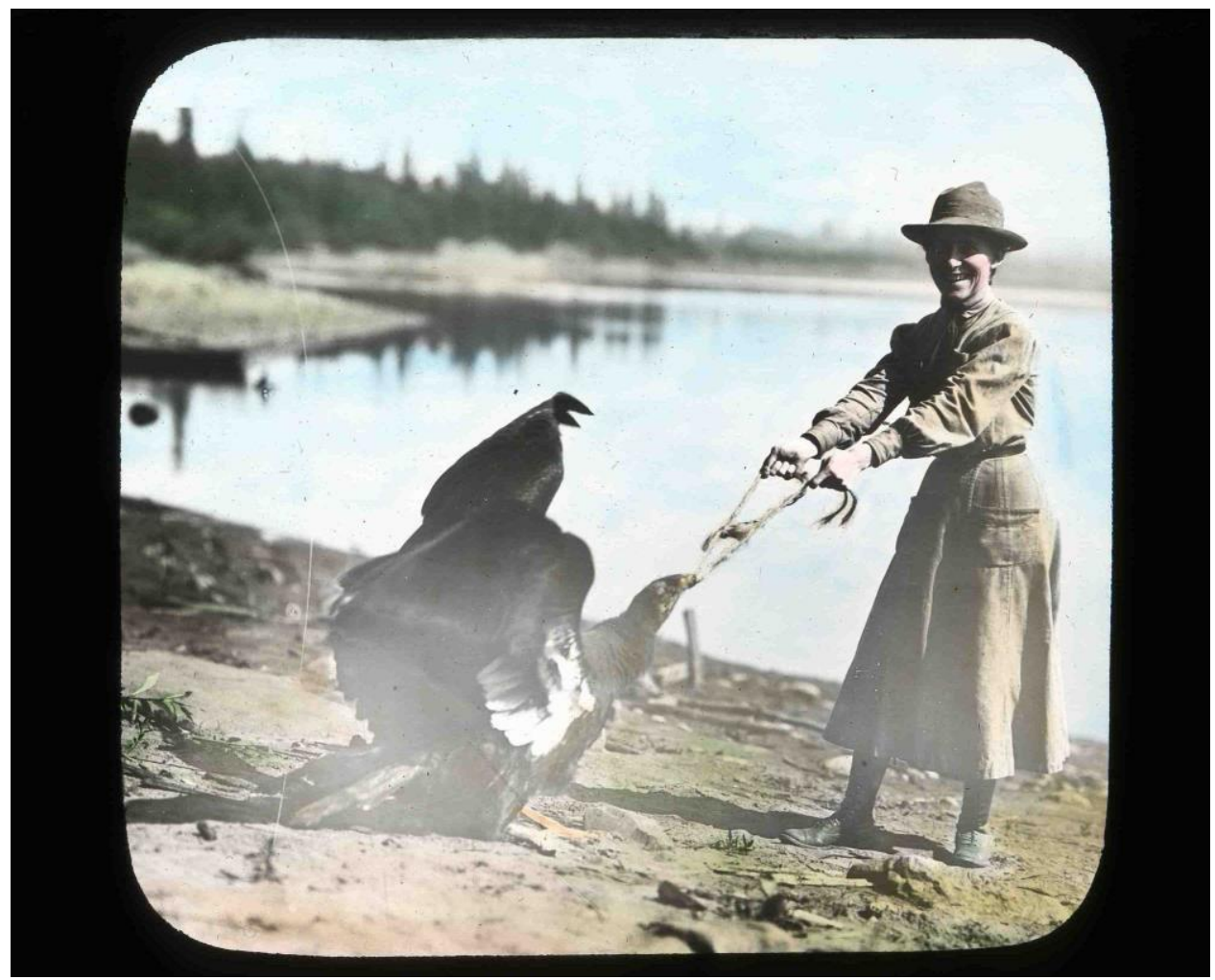

Figure 38. Irene Finley playing tug-o-war with General, 1906. Lantern slide. Audubon Society of Portland, United States Fish and Wildlife Digital Library. https://digitalmedia.fws.gov

Once the bird could fly, it would not be possible to keep him, so Finley began looking for a permanent home where General could be sent in the fall, after the photography series would be done. Since the Washington Zoo had three condors already, he thought it would be a good place for General. He hoped to "get a good price for him" as the money would come in handy to help pay for expenses, including the $\$ 400$ to $\$ 500$ in medical costs incurred by his accident on San Clemente Island. ${ }^{45}$ In the meantime, Finley was pleased with the opportunity to take many photographs of the bird.

${ }^{45}$ Ibid. 


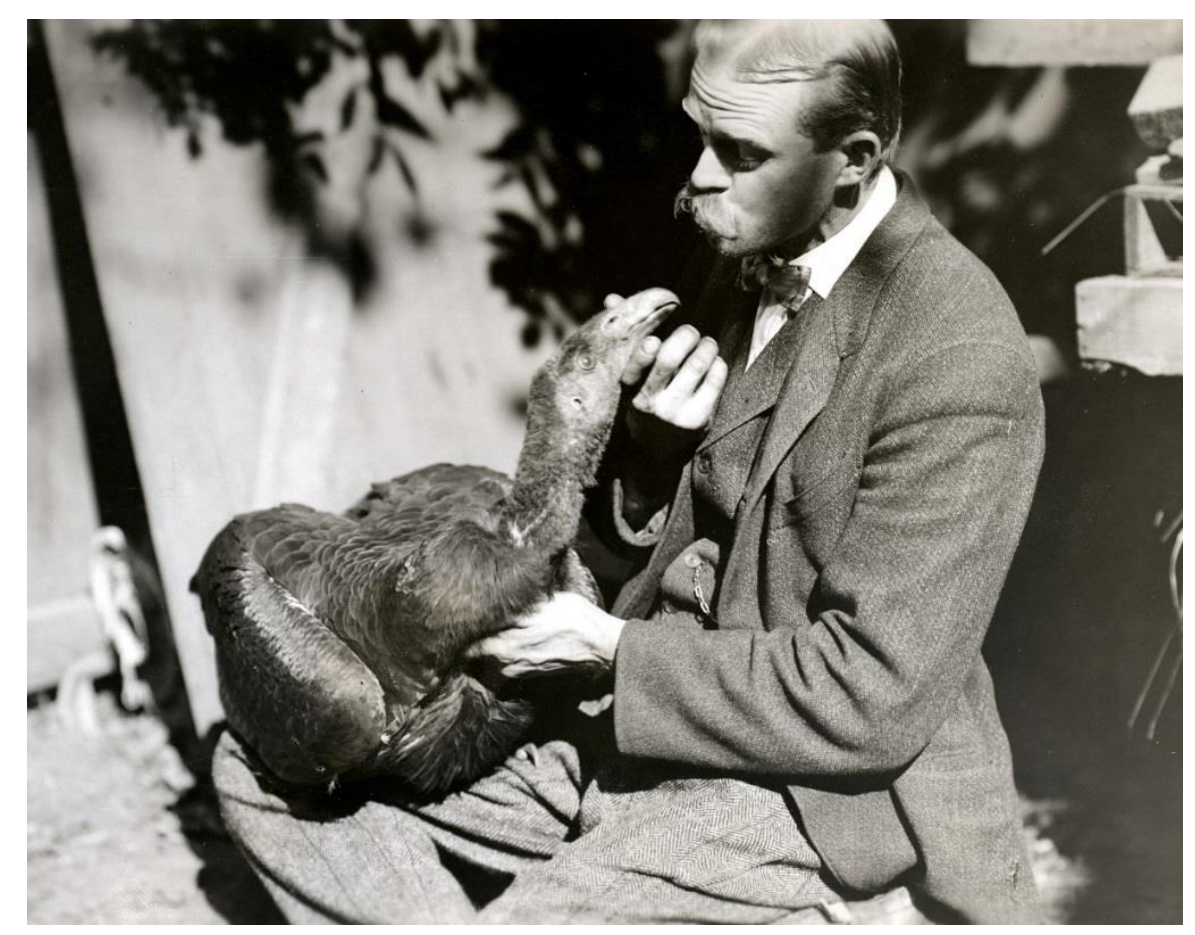

Figure 39. Herman Bohlman with General in Portland, 1906. With the permission of Museum of Vertebrate Zoology, University of California, Berkeley.

While General was living at his home Finley worked on a series on the condors for the Cooper Club journal The Condor, along with several popular magazine articles. In these pieces, he was deliberately vague about the details of the nest location, and careful that the accompanying photographs would not make the location easy to identify. Still, he worried birders in the area might figure out the specific place. ${ }^{46}$ Grinnell, who had first found the nest site, was also anxious to keep the location a secret and thought perhaps Finley was giving too much information in his various articles and lectures on the birds.

${ }^{46}$ Finley to Grinnell, Oct. 10, 1906, Joseph Grinnell papers, BL. 
Grinnell was especially concerned when an announcement appeared in Audubon's BirdLore stating the bird nest was in the mountains near Pasadena. Finley had in fact mentioned the San Bernardino Mountains to some people as a bit of misdirection, but had also tried to give Grinnell credit for his find. Since Grinnell lived in Pasadena, Finley supposed, someone had made a good guess. ${ }^{47}$

Finley's concern that the condors might be killed by collectors was not unfounded. In fact, the adult female of the nesting pair was shot two years later, and the carcass offered for sale to Dr. Grinnell for two hundred dollars. ${ }^{48}$ However, others questioned Finley's decision to take the young condor home with him. When Finley went to the annual Audubon Society meeting in New York City in October 1906, both Theodore Palmer and William Dutcher expressed concerns. W. Scott Way of the California Audubon Society had written to both accusing Finley of stealing the bird without a permit. Finley fumed, "if I were where I could reach Way I would want to give him a good punch in the eye." ${ }^{49}$ Finley showed Palmer and Dutcher the permit he had gotten from Chambers, but to ensure he and Bohlman stayed out of legal trouble he told Palmer it was Chambers who had collected and shipped the bird. Fortunately for Finley, Chambers backed his story. ${ }^{50}$

In the fall of 1906, the Washington Zoo offered seventy-five dollars for General. ${ }^{51}$ However, Finley sent General to the New York Zoo (today the Bronx Zoo). Live condors

${ }^{47}$ Finley to Grinnell, Dec. 26, 1906, Joseph Grinnell papers, BL.

${ }^{48}$ William L. Finley and Irene Barnhart Finley, Wild Animal Pets, 169-170.

${ }^{49}$ Finley to Grinnell, Oct. 30, 1906, Joseph Grinnell papers, BL.

${ }^{50}$ Finley to Grinnell, Nov. 20, 1906, Joseph Grinnell papers, BL.

${ }^{51}$ Finley to Grinnell, Sept. 13, 1906, Joseph Grinnell papers, BL. 
were much in demand for zoos due to their scarcity, and Finley was acquainted with William Temple Hornaday, then New York Zoo Director. The New York Zoo had waited four years to obtain its first California condor, a young bird taken from its nest by a boy, which had arrived at the zoo on March 14, 1905. Curator of Birds C. William Beebe described the species as "vanishing," a view that rationalized the urge to capture the birds in hopes of preserving them. ${ }^{52}$ Finley was also pessimistic about the future of the species. General was featured in a chapter of the Finleys' Wild Animal Pets. There Finley wrote that at the New York Zoo the bird had "companions, room for exercise, and plenty of wholesome food," but a page or two later observed the species could not be saved in zoos, as captive birds will not breed. Although condors do not reach maturity until they are six and may live as many as sixty years, General was not so lucky. He died at about 8 years of age. ${ }^{53}$

During the summer of 1908, Finley and Bohlman went to southeastern Oregon to finish their report on Oregon's interior wetlands for National Audubon. In 1905 they had not been able to visit all the significant nesting areas in the southern half of the state. They especially wanted to see Malheur Lake and the surrounding marshes, about 30 miles south of Burns. They left Portland on May 14, 1908, shipping Bohlman's White Steamer automobile up the Columbia River to The Dalles by boat. From there they drove south through Shaniko and Prineville to Burns. ${ }^{54}$

\footnotetext{
52 Beebe, C.W. The California Condor. Zoological Society Bulletin. New York Zoological Society. Vol 623 (1901-1906): 258-259

${ }^{53}$ W.L. Finley and Irene Finley, Wild Animal Pets, 170.

${ }^{54}$ Report of William L. Finley, Bird-Lore 10 (1908): 291-295.
} 
Using Burns as their base Finley and Bohlman made several extended trips of out into the wetlands. Bohlman had modified his car so they could use it for camping (Figure 40).

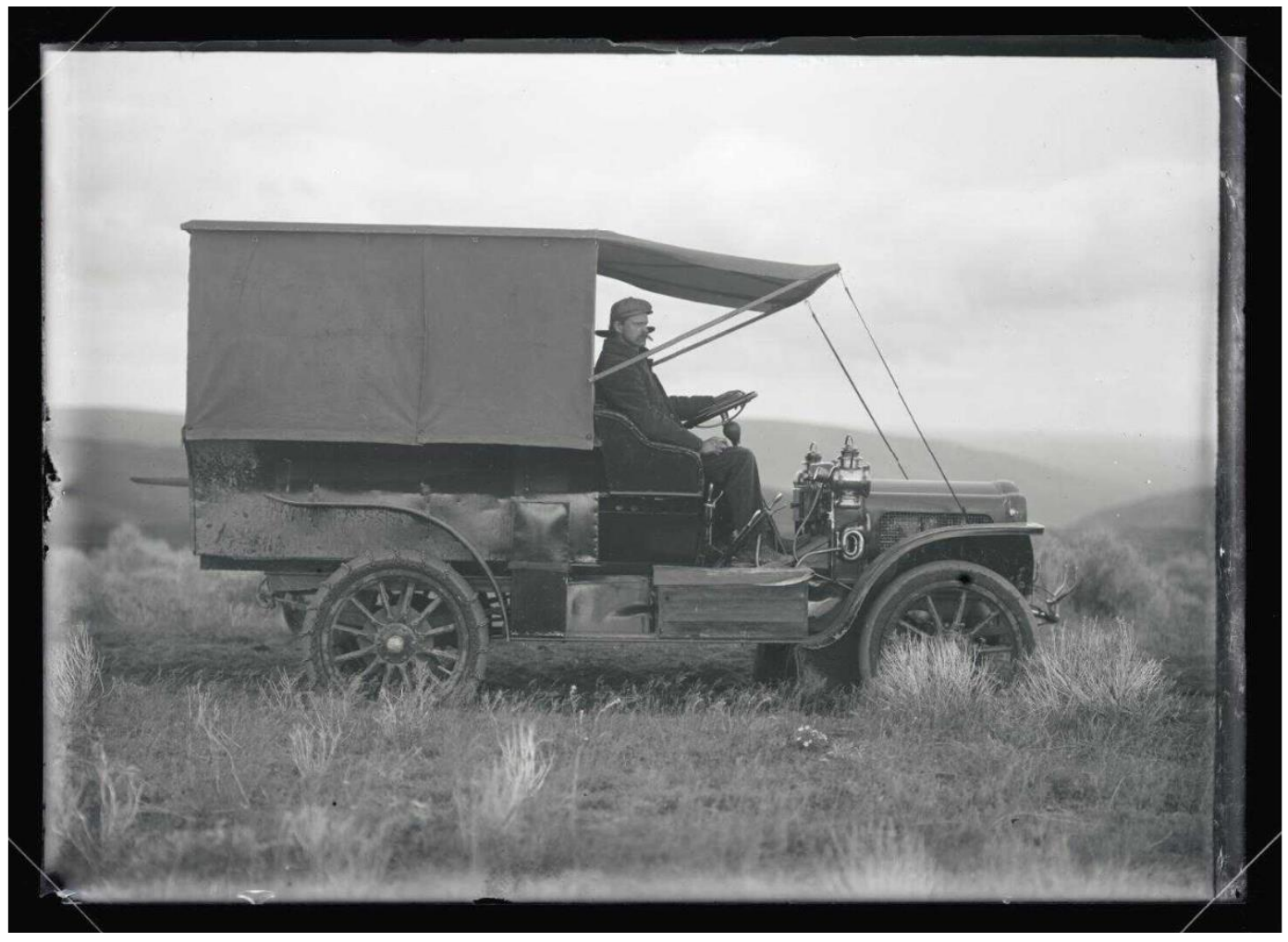

Figure 40. Bohlman at the wheel in Harney County, 1908. Finley A2299, William L. Finley Photographs Collection, OHS. 
They also explored the region by boat (Figure 41).

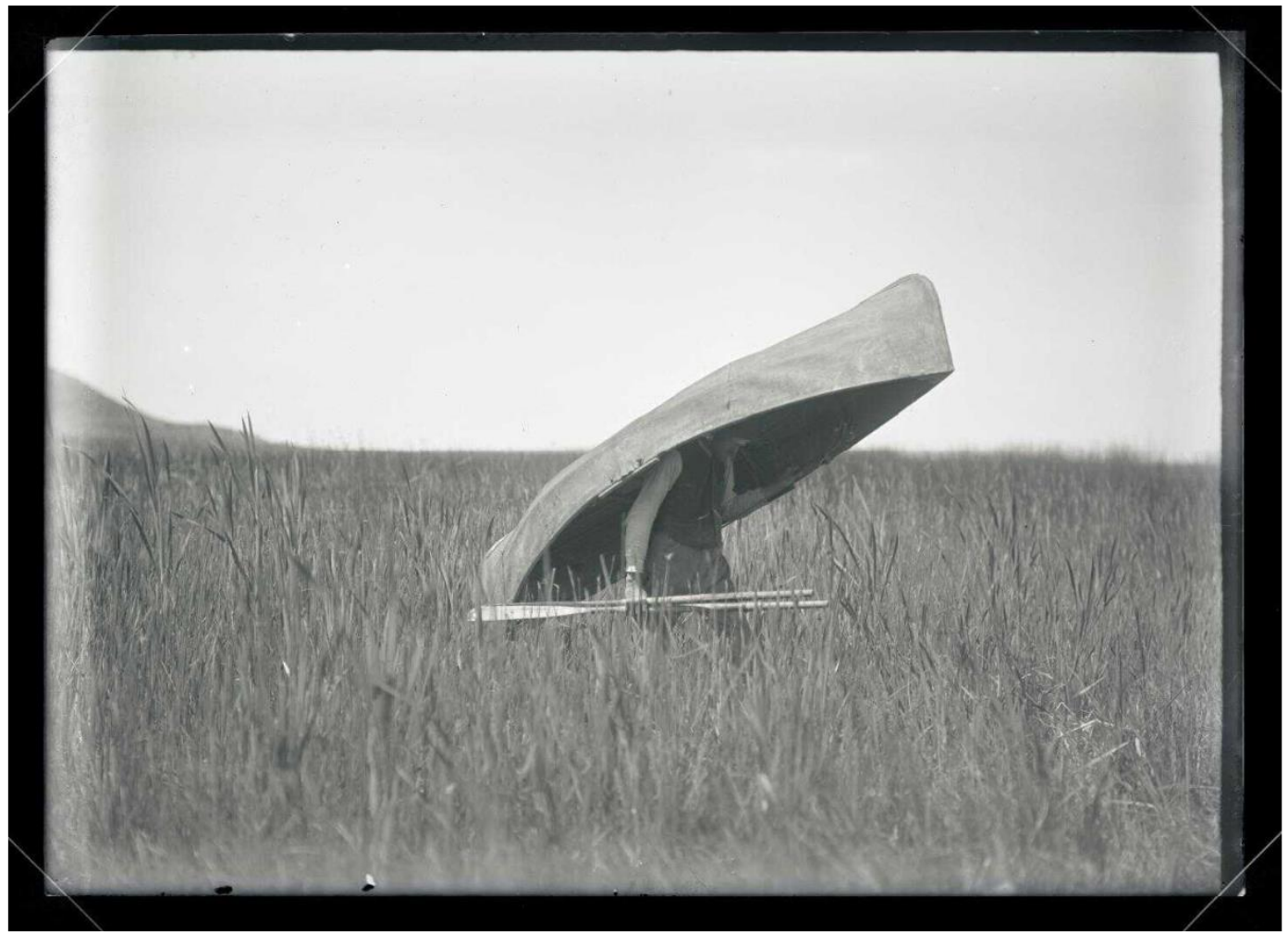

Figure 41. Bohlman carrying a canvas boat through the grass, Malheur, 1908. Finley A2313, William L. Finley Photographs Collection, OHS.

Finley noted that because Lake Malheur was just a few feet deep it was difficult to boat in. ${ }^{55}$ It was hard to walk in the marshes, too, and Finley ended up waist-deep in mud at least twice. They became lost among the tules, spending one night in the boat when they could not find their way back to camp. Finding places to camp was challenging as well. One night they slept on a muskrat house (Figure 42), but on the ${ }^{55}$ Ibid. 
second night it rained. They ended sitting up, back to back, in their boat under a small cover, waiting for daylight.

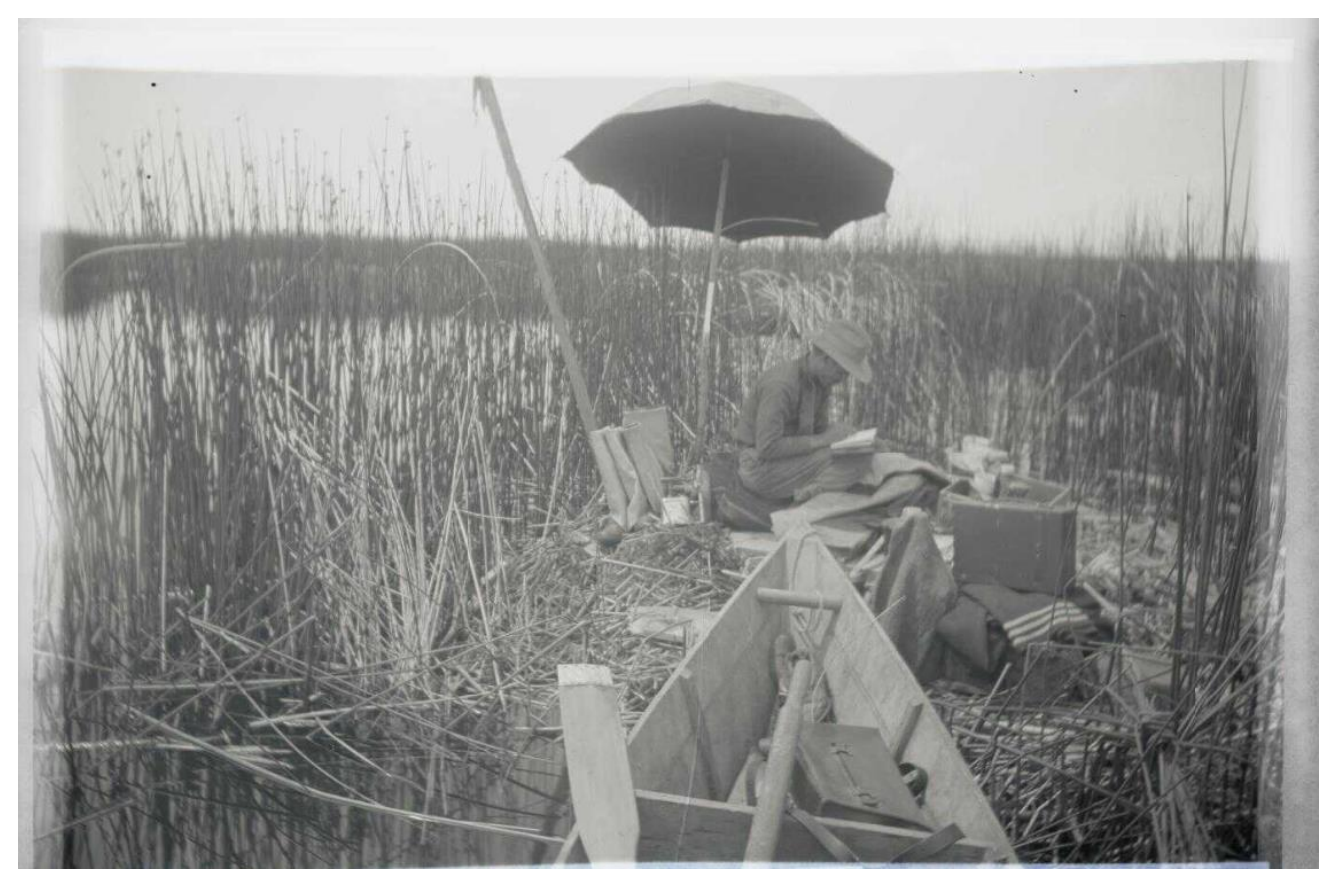

Figure 42. Finley sitting on a muskrat house, Malheur, 1908. Finley A2308, William L. Finley Photographs Collection, OHS.

They saw many ducks and geese, and discovered the largest colony of gulls and white pelicans they had ever seen. Finley wrote he was so excited he fell out of their boat holding some of their glass plate holders. ${ }^{56}$ They tried to capture the movement of so many birds in flight (Figure 43).

${ }^{56}$ William L. Finley, “The Trail of the Plume Hunter,” Atlantic Monthly, 106 (1910): 373-379. 


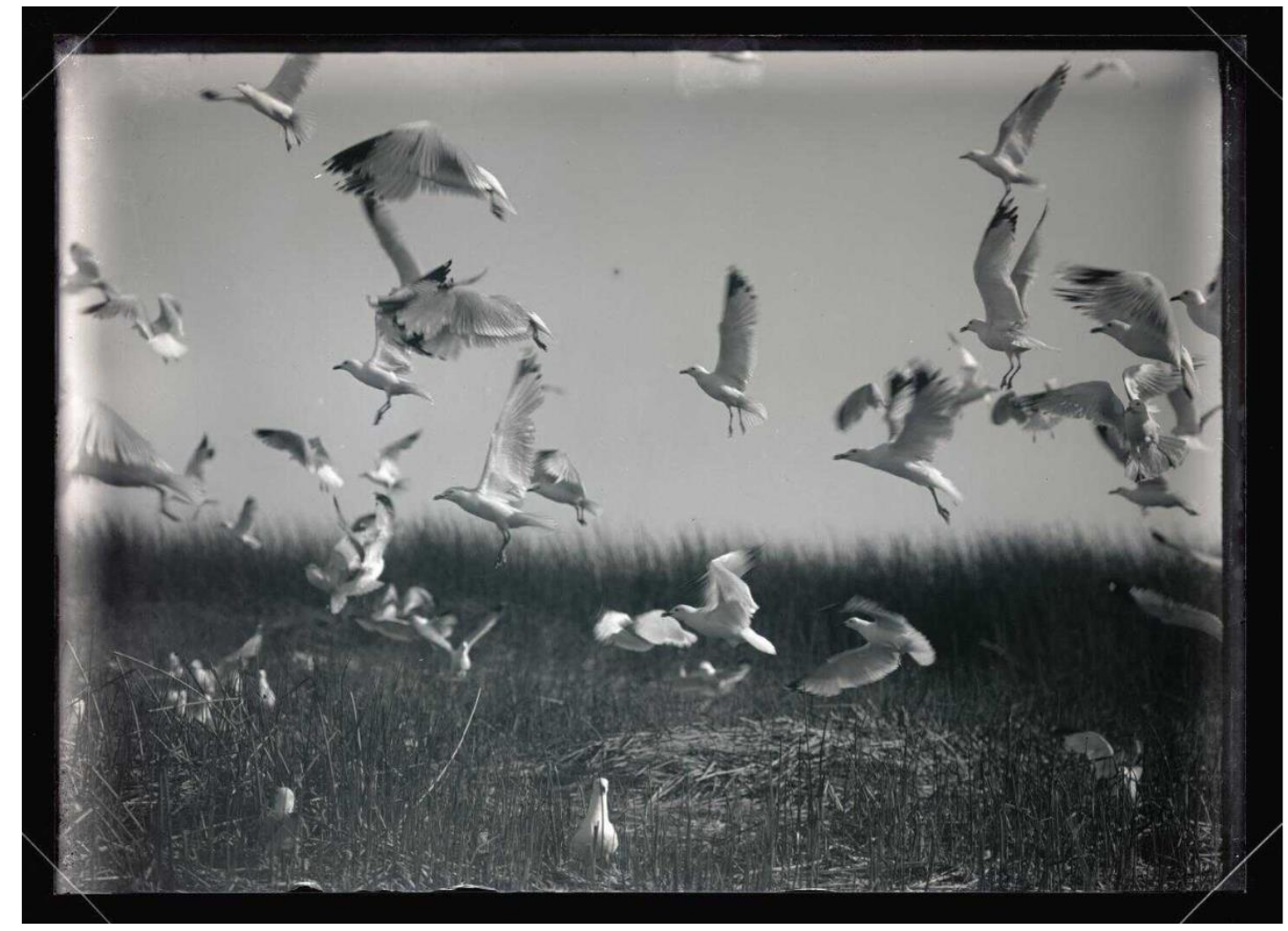

Figure 43. California gulls flying at Malheur Lake, 1908. Finley A2058, William L. Finley Photographs Collection, OHS.

They had hoped to find white egrets which had been reported in great numbers a few years before. Although they found their former nesting area, the nests held only bones. They saw just two live birds, and later realized it had likely been the same bird seen twice. They also came upon a grebe nesting area just after hunters had been through, finding dead birds stripped of the soft breast feathers and dying chicks. They took a photo of a dead grebe in the water next to two downy chicks still sitting in their nest. They used 
it for Audubon bird protection campaign flyers and later colored a lantern slide with bright red at the bird's neck. (Figure 44). ${ }^{57}$

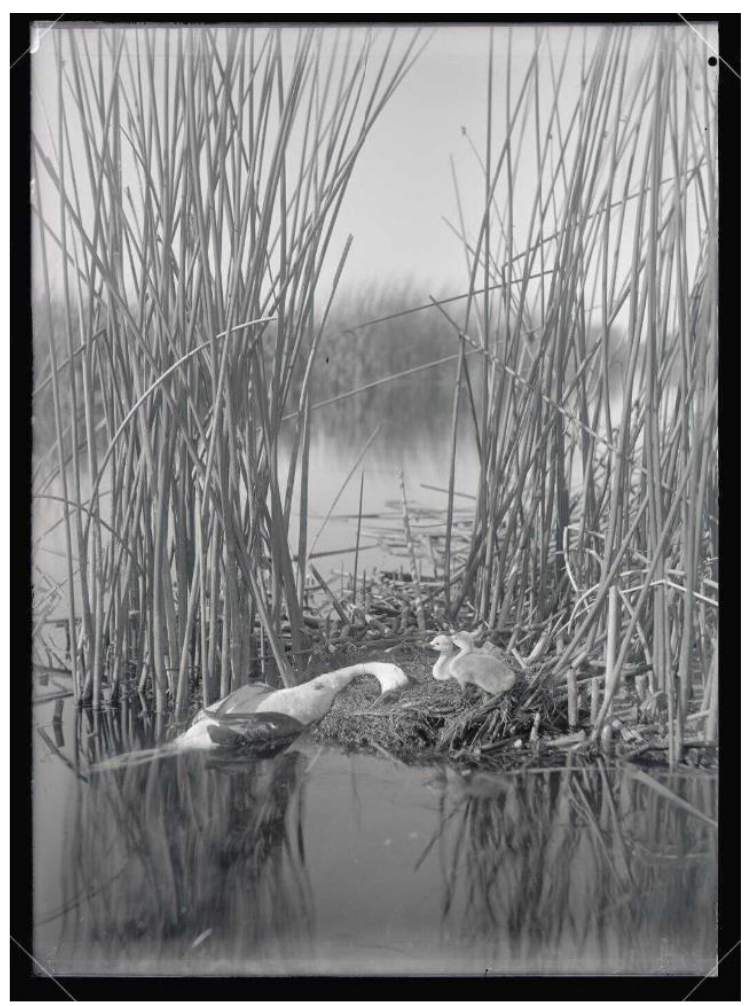

Figure 44. Dead grebe with two chicks in nest. Finley A2029, William L. Finley Photographs Collection, OHS.

The trips to the interior wetlands of Southern Oregon shifted the direction of Finley's life. He tried to convey in writing his childhood curiosity about migrating birds overhead and his desire to follow them or find their secret lands. He described riding over a peak to look down upon the Malheur valley, with the green marshes appearing like a

${ }^{57}$ Ibid. 
dream. ${ }^{58}$ Witnessing deterioration in the Southern Oregon nesting grounds over a few short years pushed Finley to further activism and stronger efforts to implement wildlife protection, but he had to do it without his former partner.

In the 1920s, comparing photography with other forms of visual art, Finley wrote that a photograph couldn't be compared with a drawing or painting. Photography, he felt, reflected a reality that a painting could not, which was a large part of its value, but also a kind of limitation. "In wild-life photography one generally has to take what he can get." Moreover, Finley stated, "by combining a technical knowledge of the camera with a sympathetic study of nature" the resulting photographs may have "artistic value." 59 Bohlman may have been a plumber by trade, but he had an artist's eye. He began landscape painting as a new avocation, leaving photography largely behind. In 1912 he joined Finley on a tour of the state with writer East Coast writer Dallas Lore Sharp, and took photos, but the 1908 trip to Malheur was he and Finley's last serious photography expedition together.

In the fall of 1908 Bohlman married Maud Bittleston, a friend of Irene Finley’s, on the Finley property by the Willamette River. Now 36, he was ready to settle down and focus on his business and family. He remained involved in the Oregon Audubon Society, painted, and was an automobile enthusiast. However, unlike Finley who enjoyed being in the public eye, Bohlman was private and reserved. ${ }^{60}$ The Finley-Bohlman photographs today are readily available, but Bohlman's paintings are not. He did not share Finley's

\footnotetext{
58 Ibid.

${ }^{59}$ William L. Finley, "Hunting Birds with a Camera."

${ }^{60}$ Mathewson, 14-15.
} 
drive to bring attention to their work. Early writing by Finley and others about how the two men worked as a team gives the impression that, despite their differences in personalities, they were compatible in their goals and views about their wildlife photography. But after nearly twenty years of working together to develop their naturalist knowledge and skills, and producing photographs, they took divergent roads.

Finley continued wildlife photography with his wife Irene, an able and willing partner in work as well as life. By 1910 he chafed at the difficulties of working across the country from the National Audubon office and the limited financial support Audubon provided for the work he wanted to do. Finances were becoming a personal issue as well. He had just been pushed off the demonstration train project by UC Berkeley faculty and the California State Game Commission. He was ready for a position with more authority, impact, and steady income. 


\section{Epilogue}

Fully Fledged: Finley’s New Direction 1910-1911

By 1910 Finley had made a name for himself as a popular nature photographer and writer, but he wasn't necessarily making a living at it. He had his position with Audubon with an annual salary, but he had to pay expenses. In addition, he was finding it onerous to have to write to the National Audubon office back East and wait for approval before taking on specific projects. He had also had a difficult year in other ways. His big trip to the Southwest with Irene had been marred by bouts of illness. He had been frustrated to have put in so much work on the demonstration train in California and then to have been dismissed. At age thirty-four, Finley was ready to be taken seriously. When he learned newly elected Governor Oswald West was looking for someone young and energetic to improve wildlife management in Oregon, Finley wanted the job.

Finley was surely not satisfied when National Audubon Secretary T. Gilbert Pearson responded to his query about the National Audubon budget for the Pacific Coast by saying Finley's salary was about all that had been budgeted. The National Society office was pressuring Finley to raise more money for the national organization, but his inclination was to raise money on the West Coast for work he could direct himself. ${ }^{1}$

\footnotetext{
${ }^{1}$ Finley to T. Gilbert Pearson, Nov. 9, 1910; T. Gilbert Pearson, Nov. 25, 1910, Folder 2, Correspondence Nov. 1910-Dec. 1910, Box 20, Series 3, William L. Finley papers, 1899-1946 (MSS Finley), Oregon State University Special Collections and Archives Research Center, Corvallis, Oregon (hereafter cited as Finley Papers, OSU).
} 
By December 1910 Finley decided the West Coast needed its own office of the National Audubon Society. He responded to Pearson's complaint about the lack of fundraising for National Audubon by arguing for such an office. "Things are quite different out here from the East," Finley wrote Pearson. Westerners, he noted, were reluctant to give money they believed would be spent on projects in the East. Finley cited a recent local newspaper editorial complaining that only $25 \%$ of the money raised by a harvest of timber in the Crater Lake Forest Reserve would be spent in Oregon while the rest would go to the "'Forest Bureaucracy of Washington." He reminded Pearson that Theodore S. Palmer, in his dual roles with the Biological Survey and National Audubon, wanted Audubon to fund a raise for L. Alva Lewis, one of the Southern Oregon game wardens, because the Biological Survey could not. This was the sort of project, Finley argued, for which people would contribute to a West Coast Audubon office; furthermore, they would then see the National Audubon Society as a truly national organization, "western as well as eastern."2

While negotiating with Pearson, Finley's mind was also on the state of Oregon's management of wildlife. Finley's experience coordinating game wardens for Audubon had made him acutely aware that state wildlife management was underfunded. The state did employ a State Game and Forestry Warden at a salary of one hundred dollars a month plus expenses. In addition, there were a number of deputy wardens paid varying amounts for services and expenses. ${ }^{3}$ However, the existing game warden system required one or

\footnotetext{
${ }^{2}$ Finley to T. Gilbert Pearson, Dec. 18, 1910, Finley Papers, OSU.

${ }^{3}$ Oregon Secretary of State, Biennial Report of the Secretary of State of the State of Oregon to the Twentyfifth Legislative Assembly for the Period of 1906-1908, 1909, 396-397; Oregon Secretary of State, Biennial
} 
two men to attempt to enforce regulations over large portions of the state-an impossible task. Finley wanted to create funding for more wardens to enforce regulations already on the books. He believed he could make a case for more money to the Oregon state legislature on the basis of economic benefits of wildlife and that it was possible to raise revenue through partnerships with sportsmen that Oregon could direct toward wildlife management.

The Oregon State Legislature had created a State Game Fund in 1905, funded by \$1 hunting licenses and in 1909 added a similar license requirement for anglers. However, the Legislature did not specify who was responsible for the Fund or how the money from license sales should be spent. ${ }^{4}$ Licenses were issued by counties, not directly by the state and, with little recordkeeping, by late 1910 no one knew how much money should be in the State Game Fund. California had a Fish and Game Commission charged with protecting wildlife using funds from hunting and angling licenses. Finley fixed his ambition on establishing something similar in Oregon.

When Oswald West was elected Governor he worried about private abuse of natural resources and believed federal and state cooperation would be necessary for efficient management of Oregon's timber, water, fish and wildlife. Sharing West's concerns, Finley saw a chance to gain a key role in West's Progressive vision for state government. He set his sights on an appointment as State Game Warden.

Report of the Secretary of State of the State of Oregon to the Twenty-sixth Legislative Assembly for the Period of 1908-1910, Secretary of State 1911, 257-258.

${ }^{4}$ Although State Game and Forestry Warden Robert O. Stevenson did hire more deputy game wardens in 1908. See Rymon, Critical Analysis of Wildlife Conservation in Oregon. 
Finley and Klamath game warden L. Alva Lewis had previously discussed the possibility of Lewis getting appointed State Game and Forestry Warden. They shared frustration that the current State Warden, Robert O. Stevenson, was unwilling to act upon their suggestions for innovations in game and wildlife management. ${ }^{5}$ Now that Finley saw the likelihood of expanding the scope of the State Game Warden position, he let Lewis know of his own interest in the job. Lewis told Finley that if he wanted the job he should "go for it." Lewis wrote Finley was "a strong candidate as you are well known as an authority on game and birds, and your appointment would give general satisfaction." He offered to round up support among Forestry officers and to talk to local Republicans he suspected had supported West in the election. He noted Finley's appointment might be politically expedient. ${ }^{6}$ Although West was a Democrat, he had friends in the Republican party, including his future brother-in-law Ben W. Olcott, who ran his election campaign. Finley agreed with Lewis that, as he was not really a party man, he might be acceptable to both Democrats and Republicans. ${ }^{7}$

Finley contacted friends and associates within the state and around the country to ask them to recommend him for the position. He wrote Theodore S. Palmer, then Assistant Chief of the Bureau of Biological Survey and Vice-President of the National Audubon Society, asking for his support, and to T. Gilbert Pearson, Secretary of National Audubon, pointing out that if he were successful in obtaining the Game Warden job he

\footnotetext{
${ }^{5}$ Finley to Lewis, Dec. 23, 1910, Finley Papers, OSU

${ }^{6}$ Lewis to Finley, Dec. 18 1910, Finley Papers, OSU.

${ }^{7}$ Finley to Lewis Dec 23 1910, Finley Papers, OSU.
} 
would be in a better position to support the National Audubon agenda in the state. ${ }^{8}$

Finley got letters of support from a variety of people including C.S. Jackson, editor of the

Oregon Journal, President Campbell of the University of Oregon, State Engineer John

Lewis, the State Superintendent of Schools, and several judges. Finley also had support

from Senator George Chamberlain Congressman Willis C. Hawley and new Railroad

Commissioner Frank Miller. ${ }^{9}$

On December 20, 1910, Finley wrote to Ben W. Olcott, incoming Secretary of

State, to formally request consideration for the appointment as State Game and Forestry

Warden. ${ }^{10}$ Finley also asked for time with West to discuss game laws, regardless of

whether the Governor was considering him for the Game Warden job. ${ }^{11}$ By early January

of 1911 Finley was working at West's request on a bill that would create a new

commission. Lewis sent Finley some advice on the best form of organization, noting that

with separate game warden and fish master positions, friction between the two was likely

to continue even with a single commission overseeing both. Lewis cautioned

${ }^{8}$ T.S. Palmer declined to support Finley in his capacity with the Biological Survey, suggesting the Forest Service was closer to game management and that Finley should solicit support there, and then wrote a supportive letter recommending Finley to West as an executive office of the National Audubon Society instead. T.S. Palmer to Finley, Dec. 24, 1910, Finley Papers, OSU.

${ }^{9}$ Finley to Lewis Dec 23 1910, Finley Papers, OSU.

${ }^{10}$ Olcott was appointed Secretary of State by West in 1911 when Frank Benson, whose illness had required Jay Bowerman to become Acting Governor, died while still holding the office of Secretary of State. Olcott served as Oregon Governor himself when Governor James Withycombe died in office in 1919 while Olcott was still serving as Secretary of State. Olcott lost the next election to the Klan-supported Democratic candidate Walter M. Pierce.

${ }^{11}$ Finley to Ben W. Olcott, Dec. 20, 1910, Finley Papers, OSU. Two versions of the letter appear in Finley's papers-one indicating he had also written directly to West, and the other with no mention of such a letter. 
"considerable jealousy exists between the salmon men and the sportsmen at present and this may be the cause of the whole plan failing."12

Finley's bill succeeded. In 1911 the Oregon Legislature replaced Oregon's Board of Fish Commissioners with a State Board of Fish and Game Commissioners. Finley had designed the Board to be as nonpartisan as possible and geographically representative of the entire state. The Governor could appoint four members, no more than two from the same political party. Two Commissioners should reside east of the Cascade Range, and two west. Those four members would choose the fifth member to complete the commission. The Board was given authority over revenue from hunting and angling licenses and fines to use for protection and propagation of fish and game. The Commission was also charged with appointing a State Game Warden and a Master Fish Warden, posts that had previously been filled by direct appointment of the Governor. Finley's intention in having the Commission select the State Wardens was to reduce political interference and promote consistency in state wildlife management. ${ }^{13}$

With a long strategy in mind, Finley now decided to try for a spot on the new commission. This surprised Lewis, who wrote "for the life of me I cannot see your object." ${ }^{14}$ Finley did still want to be State Game Warden, though Theodore Palmer of National Audubon discouraged him. Palmer worried a job as Oregon Game Warden would interfere with Finley's ability to effectively serve the Pacific Coast region as

\footnotetext{
${ }^{12}$ Lewis to Finley, Jan. 5, 1911, Folder 3, Correspondence Jan. 1911-May 1911, Finley Papers, OSU.

${ }^{13}$ William L. Finley. Game and Fish Protection and Propagation in Oregon 1911-1912. Portland: Boyer Printing Company.

${ }^{14}$ Lewis to Finley, Feb. 23, 1911, Finley Papers, OSU.
} 
Audubon's field agent. He recommended Finley take a spot on the Commission instead. ${ }^{15}$ Finley acknowledged Palmer's concerns, but thought he could improve the warden situation in Oregon with more authority and funds. He also told Palmer he couldn't afford to be a Board Commissioner long-term; it would be too much unpaid work. ${ }^{16}$

By joining the Board first, Finley calculated that he could weigh in on the selection of the fifth member and make a pitch to the rest of the Board for himself as the most qualified candidate for State Game Warden. By answering to a commission that was at least bipartisan and made up of men with interest and some knowledge of game and wildlife management, he could then implement his long-term vision for wildlife management in the state - a robust system of game law enforcement by wardens supported by a stable source of funding; close partnerships with federal agencies, sportsmen, and business; and educational programs and high-profile projects, especially related to propagation of game, to encourage public support for the Commission's work and for wildlife protection in general.

Governor West took his time setting up the new commission. In early March of 1911, the Oregonian reported that Finley had been selected by West, but Finley had not heard from West directly. West was still making decisions about other potential commissioners. Lewis warned Finley that Stevenson, who knew of Finley's interest in the job of State Game Warden, was declaring it his opinion that Finley would not accept an

15 T.S. Palmer to Finley, March 13, 1911, Finley Papers, OSU.

${ }^{16}$ Finley to T.S. Palmer, March 18, 1911, Finley Papers, OSU. Commissioners would be paid a five dollar per diem while the Board was in session, and this amount could not exceed $\$ 100$ annually. Commissioners could also be reimbursed for traveling expenses. William L. Finley, Game and Fish Protection and Propagation in Oregon 1911-1912 (Portland, Ore.: Boyer Printing, 1912). 
appointment as a commissioner. ${ }^{17}$ Finley quickly wrote Governor West to say that although he has heard "it is being reported around by certain people" that Finley would not accept a commissioner appointment, he certainly would. ${ }^{18}$ In May of 1911 the new Board of Fish and Game convened, with Finley as a Commissioner. He successfully persuaded the other commissioners to hire him as State Game Warden and then resigned from the Board to fill the post, stepping into his first full-time professional position.

Finley had successfully established himself professionally as a popular naturalist and wildlife manager. He now had a wealth of experience and contacts to draw on. $\mathrm{He}$ quickly implemented highly visible projects such as the reintroduction of elk at Billy Meadows in Eastern Oregon, the Rainbow railroad car to restock trout, and the magazine Oregon Sportsman. His tenure with the Game Commission was rocky, though. His working style was not well suited to the day-to-day running of a government agency. ${ }^{19} \mathrm{In}$ 1919 he was fired as the Game Commissioners lost patience with his independence, concern for non-game species and general habitat, as well as his persistent campaigning for improvements of conditions at the Malheur and the Klamath Basin bird refuges.

By then he realized the best use of his talents was as a popularizer of conservation ideas. He likely came into family money at about this time, and no longer needed the

\footnotetext{
${ }^{17}$ Lewis to Finley, Mar. 7, 1911, Finley Papers, OSU.

${ }^{18}$ Finley to West, March? 1911 (Complete date not legible.), Finley Papers, OSU.

${ }^{19}$ Governor West, to his chagrin, discovered Finley, along with the Fish Master and the Board of Commissioners, did little record-keeping of accounts. He fired two commissioners in 1914 to make room for new appointees who would follow West's direction. They shifted Finley to the State Biologist position. The Board of Commissioners soon reasserted itself and reinstated Finley as Game Warden. In 1917 he took on the State Biologist position again, which gave him time to work on Oregon Sportsman, supervise game farms, and continue his lecturing and field work.
} 
financial security of a steady job. ${ }^{20} \mathrm{He}$ had never given up his lecture tours, field work and lobbying with Audubon entirely, but he was now more free to pursue them. He partnered with his wife Irene, and Arthur Newton Pack of the American Nature Association, to make wildlife films, and continued writing for a general audience. He also teamed with Jay "Ding" Darling and Ira N. Gabrielson on the issue of conditions at the bird refuges in Southern Oregon. ${ }^{21}$ They achieved some success with the federal government's 1935 purchase of about 65,000 acres and water rights on the Blitzen River to be added to the Malheur Wildlife Refuge, but the degradation of the Southern Oregon bird refuges was a painful continuing disappointment.

When I began investigating William Finley's work as a conservationist, I was puzzled by the variety of his activities and the incongruous ways he was portrayed in different historical accounts. Hence this thesis had a modest goal— to put together Finley's seemingly scattered contributions and make sense of how he created his unusual career. I also hoped to fill in details of his life within the broad contours of what was generally known. Thus this work emphasizes Finley’s photography partnership with Herman Bohlman and participation in ornithology organizations as the foundation to his broader career. Further scholarship on Finley's life and work could include the role of

\footnotetext{
${ }^{20}$ To illustrate Finley's new ease about his personal finances, shortly after he was fired, the Finleys replaced their small house at Jennings Lodge on the Willamette River with a much grander home designed by Portland architect Wade Hampton Pipes.

${ }^{21}$ Darling was a conservationist and Pulitzer Prize winning cartoonist who led the Biological Survey in the 1930s and created the federal Duck Stamp. Gabrielson had worked for the Biological Survey in the Pacific Northwest and when the Survey became U.S. Fish and Wildlife, Gabrielson was its first director.
} 
social and professional networks in conservation, wildlife management in the Pacific Northwest, and early popular science communication.

Full consideration of Finley's life and career will likely contribute to recent scholarship in environmental history that moves beyond earlier arguments about conservation vs. preservation and whether man stands apart or is a part of nature, to present alternative narratives of how Americans thought about their relationship to wilderness and wildlife. Finley was highly connected in the American conservation movement, and so was both influenced by and an influence on the ideas of others. As a popular communicator through writing and film, he was in position to disseminate emerging ideas of scientists and the new class of professional wildlife managers to the general public. Through his association with Audubon, he also connected the concerns of such professionals with the Audubon movement's grassroots activist agenda. Further investigation of his life and work will contribute to our understanding of how American ideas about the environment travelled and evolved. In his writing, filmmaking, and photographs, William Finley portrayed birds as both beautiful and valuable. His ability to convey the joy he felt engaging with wildlife speaks to us across the years, and is in the end, his most lasting legacy. 


\section{Bibliography}

Primary Sources:

Archive Collections:

Herman T. Bohlman Photograph Collection ca. 1898-1925 (P202), Oregon State University Special Collections and Archives Research Center, Corvallis, Oregon.*

William L. Finley Letters and Scrapbook, MSS 2654, Oregon Historical Society Research Library, Portland, Oregon.

William L. Finley Papers, MSS Finley, Oregon State University Special Collections and Archives Research Center.*

William L. Finley Photographs Collection, circa 1900-1940 (Org Lot 369), Oregon Historical Society Research Library.*

Joseph Grinnell Papers, BANC MSS C-B 995, The Bancroft Library, University of California, Berkeley.

Joseph and Hilda Wood Grinnell Papers, U BANC MSS 73/25 c, The Bancroft Library, University of California, Berkeley.

Oregon Audubon Society Records, MSS 2990, Oregon Historical Society Research Library. 
*Portions of these collections can now be accessed through Oregon Digital in the set "Reuniting Finley and Bohlman." https://oregondigital.org/sets/finley-bohlman

Writings of William L. Finley:

Finley, William L. “An Adventure in Modern Photography.” The Pacific Monthly. Vol. 13 (January 1905): 16-23.

. American Birds, Studied and Photographed from Life. New York: C. Scribner's Sons, 1907.

—_. "Among the Gulls on Klamath Lake." The Condor 9, no. 1 (1907): 12-16.

—. "Among the Pelicans". The Condor 9, no. 2 (1907): 35-41.

—. "Among the Sea Birds of the Oregon Coast." The Condor 4, no. 3 (1902): 53-57.

—. "Among the Sea Birds off the Oregon Coast, Part I." The Condor 7, no. 5 (1905): 119-27. . "Among the Sea Birds off the Oregon Coast, Part II." The Condor 7, no. 6 (1905): 161-69.

—_. "The Barn Owl and Its Economic Value." The Condor 8, no. 4 (1906): 83-88.

_. "The Bird of Night." The Pacific Monthly 13 (1905): 350-357.

—_. "Catching Birds with a Camera." The Condor 3, no. 6 (1901): 137-39.

—_. "The Cruise of Two Camera Hunters." The Pacific Monthly. 23 (1910): 631-641.

—. "Feathered Foragers," Sunset 19, no. 4 (August 1907): 382-387.

—_. "The Golden Eagles of Mission Ridge." San Francisco Call, October 21, 1906.

—_."The Grebes of Southern Oregon". The Condor 9, no. 4 (1907): 97-101.

_. "Home life of the California Condor." Century Illustrated, 75 (1908): 370-380. 
—. "Hunting Birds with a Camera: A Record of Twenty Years of Adventure in Obtaining Photographs of Feathered Wild Life in America.” National Geographic. (August 1923):160-201.

—. "Life History of the California Condor. Part I. Finding a Condor's Nest." The Condor 8, no. 6 (1906): 135-42.

— . "Life History of the California Condor Part III. Home Life of the Condors." The Condor 10, no. 2 (1908): 59-65.

—. "Life History of the California Condor Part IV. The Young Condor in Captivity." The Condor 12, no. 1 (1910): 5-11.

—. "Photographing in a Heron Village." Pacific Monthly, 13 (1905): 296-301.

—. "Photographing the Aerie of a Western Red-Tail." The Condor 7, no. 1 (1905).

Cooper Ornithological Society: 3-7.

—. “A Study in Bird Confidence." The Condor 7, no. 4 (1905): 91-95.

—. "Study of Birds and Their Economic Value," Leaflets Listing and Describing

Birds of Oregon; No. 1. Portland, Or: [Oregon State Biologist], 1907.

—. "The Trail of the Plume Hunter.” Atlantic Monthly, 106 (1910): 373-379.

—. "Two Vireos Caught with a Camera." The Condor 5, no. 3 (1903): 61-64.

Finley, William L. and Irene Finley. Little Bird Blue. Boston: Houghton Mifflin Co., 1915.

Finley, William L. and Irene Barnhart Finley. Wild Animal Pets. C. Scribner's Sons, 1928. 
Finley, William L., and Oregon. State Board of Fish Game Commissioners. Game and Fish Protection and Propagation in Oregon, 1911, 1912. Portland: Boyer Print., 1912.

William L. Finley short films:

Finley, William L. and Irene Finley. Chumming with Chipmunks. 1921. Bray Studios. $\underline{\text { https://archive.org/details/chumming_with_chipmunks_1921 }}$

—.Mount McKinley National Park. 1930. Nature Magazine. Digitized from film reels, William L. Finley Papers, 1899-1946 (MSS Finley), Oregon State University Special Collections and Archives Research Center, Corvallis, Oregon. https://oregondigital.org

—. The Pribilof Islands. 1930. Nature Magazine. Digitized from film reels, William L. Finley Papers, 1899-1946 (MSS Finley), Oregon State University Special Collections and Archives Research Center, Corvallis, Oregon. https://oregondigital.org

—. Wild Animal Outposts. 1926. Nature Magazine. Digitized from film reels, William L. Finley Papers, 1899-1946 (MSS Finley), Oregon State University Special Collections and Archives Research Center, Corvallis, Oregon. https://oregondigital.org

Finley, William L. and Arthur N. Pack. Back into the Ages. 1924. American Nature Association. MI 04261, Oregon Historical Society. 
—. Back into the Ages. 1924. American Nature Association. MI 04262, Oregon Historical Society

_. Canadian Geese. 1917. American Nature Association. MI 04255, Oregon Historical Society.

The Forests. 1927. American Nature Association. Digitized from film reels, William L. Finley Papers, 1899-1946 (MSS Finley), Oregon State University Special Collections and Archives Research Center, Corvallis, Oregon. https://oregondigital.org

—. Getting Our Goat. 1930. American Nature Association. Digitized from film reels, William L. Finley Papers, 1899-1946 (MSS Finley), Oregon State University Special Collections and Archives Research Center, Corvallis, Oregon. $\underline{\text { https://oregondigital.org }}$

_. Glaciers and Whales. 1926. American Nature Association. MI 01576, Oregon Historical Society.

—. The Great Bear of Alaska. 1926. American Nature Association. MI 01579, Oregon Historical Society.

_. Incomplete Film Segments. 1930. American Nature Association. Digitized from film reels, William L. Finley Papers, 1899-1946 (MSS Finley), Oregon State University Special Collections and Archives Research Center, Corvallis, Oregon. $\underline{\text { https://oregondigital.org }}$ 
- In the Wake of the Wapiti. 1927. Digitized from film reels, William L. Finley Papers, 1899-1946 (MSS Finley), Oregon State University Special Collections and Archives Research Center, Corvallis, Oregon. https://oregondigital.org —. Off to Glacier Bay. 1926. American Nature Association. MI 01575, Oregon Historical Society.

- The Passing of the Marshlands. 1930. American Nature Association. Digitized from film reels, William L. Finley Papers, 1899-1946 (MSS Finley), Oregon State University Special Collections and Archives Research Center, Corvallis, Oregon. https://oregondigital.org

—. Pueblo and Navajo 1925 American Nature Association. MI 04263, Oregon Historical Society.

—. Skagway River and St. George Island in Alaska. n.d. American Nature Association. MI 03235, Oregon Historical Society.

—. Thar She Blows. 1926 American Nature Association. MI 01577, Oregon Historical Society.

Other Primary Sources

Ancestry.com. 1850 U.S. Federal Census - Slave Schedules [database on-line]. Provo, UT, USA: Ancestry.com Operations Inc, 2004. Original data: United States of America, Bureau of the Census. Seventh Census of the United States, 1850. Washington, D.C.: National Archives and Records Administration, 1850. M432, 1,009 rolls. Through HeritageQuest. https://www.ancestryheritagequest.com 
Anderson, Preston E. "Ornithological Photography: An Appreciation of Two Earnest Workers." Camera Craft. vol.14: 115-124.

Anthony, A.W. “Oregon’s Imported Songsters,” Zoe 2 (1891): 6-11.

"The Audubon Society." Forest and Stream 26 (Feb. 11, 1886): 41.

"Bird Studies and Pictures from Life with a Camera: William Lovell Finley, Herman T. Bohlman." (1905) The Craftsman, Vol 8 (1905): 613-622.

Beebe, C.W. The California Condor. Zoological Society Bulletin. New York Zoological Society. Vol 6-23 (1901-1906): 258-259.

Bohlman, Herman T. "Collecting Among Aquatic Birds," Oregon Naturalist 4, (MarchApril 1897).

Carey, Charles Henry. History of Oregon Vol II. Oregon: Pioneer Historical Publishing Co. Oregon, 1922: 384-385.

Chapman, Frank M. Bird Studies with a Camera: With Introductory Chapters on the Outfit and Methods of the Bird Photographer. D. Appleton and Company, 1900.

City Club of Portland (Portland, Or.), City Club of Portland Bulletin vol. 04, no. 27: 2 (1924-4-11). City Club of Portland. Paper 45. $\underline{\text { http://pdxscholar.library.pdx.edu/oscdl_cityclub/45 }}$ p.2

Combes, Edward. Report on Technical Education and Manual Training at the Paris Universal Exhibition of 1889, and in Great Britain, France, and the United States of America. New South Wales: G.S.Chapman, acting government printer, 1891: 228.

Editorials, The Condor 10, no. 1 (1908): 51-52. 
"Finley Drunk, Charge: Undertaker Arrested on Reckless Driving County: Motorman Says Young Man in Company With Woman Speeded Along Hawthorne Ave." Oregonian, February 22, 1920. 12:3.

Finley, Newton Gleaves. 1922. Memories of Travel Across the Plains in 1852.

Typewritten manuscript. Bancroft Library, University of California, Berkeley. BANC MSS C-D 5182.

Finley, Asa, will, text available USGenweb.com http://files.usgwarchives.net/mo/saline/wills/fnlywill.txt

Gaston, Joseph. Portland, Oregon, Its History and Builders: In Connection with the Antecedent Explorations, Discoveries, and Movements of the Pioneers that Selected the Site for the Great City of the Pacific, Volume 3. Chicago: S.J. Clarke Publishing Company, 1911.

Gleaves Family Slave Registry. Gleaves Family Website. www.gleavesfamily.com/files/descendants_of_matthew_glaves/2009_Chapter_11_Slave _Registry_pages_689-706.pdf

Grinnell, Hilda Wood. “Joseph Grinnell: 1877-1939.” The Condor, 62, no. 1 (1940): 334.

Grinnell, Joseph, and Witmer Stone. "The Functions of the A. O. U. Committee on Nomenclature." The Auk 29, no. 4 (1912): 561-68. doi:10.2307/4071827. Hall, E. Raymond. “Obituary: Joseph Grinnell.” The Murrelet, 20 (1939): 46-47. "Hunting Wild Birds with the Camera" Camera Craft, 17, no. 3 (March 1910): 127. 
Jewett, Stanley G., and Ira Noel Gabrielson. Birds of the Portland Area, Oregon, By Stanley G. Jewett and Ira N. Gabrielson. Pacific Coast Avifauna ; No. 19 (1929): 1-54.

Jewett, Stanley. 1946. From Field and Study: The starling in Oregon. The Condor 48 (1946):245

“Joint Meeting of the American Ornithologists' Union and the Cooper Club of California" The Condor, Vol. 5, no. 4 (1903): 108-109.

“Law Enforcement in Oregon.” Bird-Lore, 11, no. 4 (1909): 188.

Linsdale, Jean M. “In memoriam: Joseph Grinnell.” Auk, 59 (1942): 269-85.

Lord, William Rogers. A first book upon the birds of Oregon and Washington: a pocket guide and pupil's assistant in a study of the more common land birds and a few of the shore and water birds of these states. Portland, OR: W. R. Lord, 1902. Rev. and enlarged edition. Biodiversity Heritage Library.

Manumission certificate: Sampson Gleaves. Catalog no. 1997-214-35. Collection of History San Jose.

http://historysanjose.org/wp/wpcontent/uploads/2016/11/199721435.jpg

Manumission certificate: Plim Jackson. Catalog no. 1997-297-1. Collection of History San Jose. http://historysanjose.org/wp/wp-content/uploads/2016/11/19972971.jpg Metcalfe, Gertrude. "Birds of the Northwest: the Nesting Season". Pacific Monthly, 9, no. 4 (1903): 221-222.

“Mr. Finley Again in Good Health” Camera Craft, 17, no. 5 (1910):202.

“New Bird Photographer” Evening Star, November 22, 1905: 20. 
“New York Trade School.” The Metal Worker. Sanitary and Heating Publishing. January 6 1894: 41.

"Notes and News." The Auk. Vol. 23, No. 1 January 1906.

The Oologist, Albion, NY.,1897-1898.

Oregon Naturalist, Oregon City, Or., 1894-1897.

Oregon Secretary of State, Biennial Report of the Secretary of State of the State of Oregon to the Twenty-fifth Legislative Assembly for the Period of 1906-1908, 1909.

Oregon Secretary of State, Biennial Report of the Secretary of State of the State of Oregon to the Twenty-sixth Legislative Assembly for the Period of 1908-1910, Secretary of State 1911.

The Oregon Sportsman, Oregon, 1913-1917.

Portland (Or.) Board of Education. (1884) Annual Report of the Public Schools vol. 11, vols. 19-24: 757-758, 919.

Pigarth, "A Gun Camera,” Forest and Stream, 39 (August 1892): 92.

"Professor William Lovell Finley Will Lecture Before Audubon Society on 'Birds of the Coast'." Los Angeles Herald, Volume 32, Number 114, January 23, 1905.

“Report of William L. Finley.” Bird-Lore, 11, no. 6 (1909): 301-304.

“Roosevelt to Secure Photographs of Birds." San Francisco Call, Vol. 105, No. 106, March 16, 1909. 
Sage, Jno. H. "Twenty-second Congress of the American Ornithologists' Union," The Auk 22, no. 1, American Ornithologists' Union, 1905: 71-76.

Sharp, Dallas Lore. Where Rolls the Oregon. Boston: Houghton Mifflin, 1914.

Silz v. Hesterberg, (1908) United States Supreme Court, 211 U.S. 31. Casetext. https://casetext.com/case/silz-v-hesterberg

“State Reports: Oregon.” Bird-Lore, 7, no. 1 (1905): 103-108.

“State Reports: Oregon.” Bird-Lore, 11, no. 6 (1909): 328-329.

Swarth, Harry Schelwald. A Systemic Study of the Cooper Ornithological Club. San Francisco: n.p. 1929.

University of California, Berkeley. (1904) Register-University of California. University of California Press.

William Gleaves Family Bible, Gleaves Family website.

http://www.gleavesfamily.com/home/bibles/william_gleaves_bible.html

Secondary Sources

Alagona, Peter S. After the Grizzly Endangered Species and the Politics of Place in California. Berkeley: University of California Press, 2013.

Barrow, Mark V. Jr. Nature's Ghosts: Confronting Extinction from the Age of Jefferson to the Age of Ecology. Chicago; London: University of Chicago Press, 2009.

Barrow, Mark V. Jr. A Passion for Birds: American Ornithology After Audubon. Princeton University Press: Princeton, New Jersey, 1998. 
Benson, Etienne. "Endangered Birds and Epistemic Concerns: The California Condor," in Endangerment, Biodiversity, and Culture, ed. by Fernando Vidal and Nélia Dias. New York: Routledge, 2016.

Blackford, Mansel G. "The Lost Dream: Businessmen and City Planning in Portland, Oregon, 1903-1914." The Western Historical Quarterly 15, no. 1 (1984): 39-56. doi:10.2307/968558.

Brower, Matthew. Developing Animals: Wildlife and Early American Photography. Minneapolis: University of Minnesota Press, 2010.

Brower, Matthew. "Trophy Shots: Early North American Photographs of Nonhuman Animals and the Display of Masculine Prowess." Society \& Animals 13, no. 1 (2005): 13-32.

Cronon, William. "The Trouble with Wilderness; Or, Getting Back to the Wrong Nature." Environmental History 1, no. 1 (1996): 7-28.

Doughty, Robin W. Feather Fashions and Bird Preservation: A Study in Nature Protection. Berkeley: University of California Press, 1975.

Dunaway, Finis. Natural Visions: The Power of Images in American Environmental Reform. Chicago: University of Chicago Press, 2005.

Dunlap, Thomas R. In the Field, Among the Feathered: A History of Birders and Their Guides. New York: Oxford University Press, 2011.

Farber, Paul L. "The Transformation of Natural History in the Nineteenth Century." Journal of the History of Biology 15, no. 1 (1982): 145-52. 
Foster, J. Doug. "Necessary co-existence: Lower Klamath and Tule Lake Wildlife Refuges, Part I and Part II" in Shaw Historical Library, Wings That Fill the Sky: America's First Waterfowl Refuge. Klamath Falls, OR: Shaw Historical Library, 2008

Foster, Doug. "Refuges and Reclamation: Conflicts in the Klamath Basin, 19041964." Oregon Historical Quarterly 103, no. 2 (2002): 150-87.

Graham, Frank, Jr. The Audubon Ark: A History of the National Audubon Society. 1st University of Texas Press ed. Austin: University of Texas Press, 1992.

“Growing Up and Growing Old" Riverviews, (Summer 2016), City of Portland, Bureau of Environmental Services, https://www.portlandoregon.gov/bes/article/534311

Hays, Samuel P. "Comment: The Trouble with Bill Cronon's Wilderness." Environmental History 1, no. 1 (1996): 29-32.

Hays, Samuel P. Conservation and the Gospel of Efficiency: the Progressive Conservation Movement, 1890-1920. ACLS Humanities E-Book. Pittsburgh, Pa.: University of Pittsburgh Press, 1999.

Historical Statistics of the United States Millennial Edition Online, Table Ba4335-4360. https://hsus.cambridge.org

Jacoby, Karl. Crimes against Nature: Squatters, Poachers, Thieves, and the Hidden History of American Conservation. Berkeley: University of California Press, 2001.

Jobanek, George A. The Northwestern Ornithological Association. Oregon Birds: The Quarterly Journal of Oregon Field Ornithology, 24, no. 1: 11-17. 
Johnson, Jason B. Slavery in the Gold Rush days: New discoveries prompt exhibition, reexamination of state's involvement. San Francisco Chronicle. January 27, 2007.

Kellert, Stephen R. "Historical Trends in Perceptions and Uses of Animals in 20th Century America." Environmental Review: ER 9, no. 1 (1985): 19-33.

Kohler, Robert E. All Creatures: Naturalists, Collectors, and Biodiversity, 1850-1950. Princeton: Princeton University Press, 2006.

Kohler, Robert E. "Paul Errington, Aldo Leopold, and Wildlife Ecology: Residential Science." Historical Studies in the Natural Sciences 41, no. 2 (2011): 216-54. Langston, Nancy. Where Land \& Water Meet: A Western Landscape Transformed. Weyerhaeuser Environmental Books. Seattle: University of Washington Press, 2003.

Lipin, Lawrence M. Workers and the Wild: Conservation, Consumerism, and Labor in Oregon, 1910-30. Working Class in American History. Urbana: University of Illinois Press, 2007.

Lutts, Ralph H. The Nature Fakers: Wildlife, Science \& Sentiment. Golden, Colo.: Fulcrum, 1990.

Mark, Stephen R. Conflict and Compromise: William Finley and the Revival of Lower Klamath Lake. In Shaw Historical Library, \& Oregon Tech Development Foundation. (2008). Wings that fill the sky: America's first waterfowl refuge. (Journal of the Shaw Historical Library; v. 22). Klamath Falls, OR: Shaw Historical Library. 
Mason, Kathy S. "Out of Fashion: Harriet Hemenway and the Audubon Society, 18961905." Historian 65, no. 1 (2002): 1-14.

Mathewson, Worth. William L. Finley, Pioneer Wildlife Photographer. Corvallis, Or.: Oregon State University Press, 1986.

McAllister, Tom, “Our First 50 Years-1902-1952,” Audubon Society of Portland website, under History. http://audubonportland.org/files/first50

Merchant, Carolyn. Spare the Birds!: George Bird Grinnell and the First Audubon Society. New Haven: Yale University Press, 2016.

Merchant, Carolyn. "Women of the Progressive Conservation Movement, 1900-1916." Environmental Review 8, no.1 (spring 1984): 57-85.

Mighetto, Lisa. "Science, Sentiment, and Anxiety: American Nature Writing at the Turn of the Century." Pacific Historical Review 54 (1985): 33.

Mitman, Gregg. Reel Nature: America's Romance with Wildlife on Film. Weyerhaeuser Environmental Classic ed. Weyerhaeuser Environmental Classics. Seattle: University of Washington Press, 2009.

Moss, Jeffrey W., and Cynthia B. Lass. "A History of Farmers' Institutes." Agricultural History 62, no. 2 (1988): 150-63. http://www.jstor.org.proxy.lib.pdx.edu/stable/3743290.

Munford, Kenneth, “The Oregon and California Railroad” Horner Museum Tour Guide Series, Benton County Historical Society website, http://www.bentoncountymuseum.org/index.php/research/sites-of-interest/hornermuseum-tour-guide-series/the-oregon-and-california-railroad-1978 
Nash, Roderick Frazier. Wilderness \& the American Mind, 4th edition. New Haven: Yale University Press, 2001.

Orr, Oliver H. Saving American Birds: T. Gilbert Pearson and the Founding of the Audubon Movement. Gainesville: University Press of Florida, 1992.

Paul, Rodman W. "After the Gold Rush: San Francisco and Portland." Pacific Historical Review 51, no. 1 (1982): 1-21. doi:10.2307/3639818.

Perez, Kim. "'Nature as a Field for Fiction": Mabel Osgood Wright Responds to the Nature Faker Controversy." Interdisciplinary Studies in Literature and Environment 19, no. 1 (2012): 24-42.

Petterson, Palle B. Cameras into the Wild: A History of Early Wildlife and Expedition Filmmaking, 1895-1928. Jefferson: McFarland \& Company, Publishers, 2011. Philippon, Daniel J. Conserving Words: How American Nature Writers Shaped the Environmental Movement. Athens: University of Georgia Press, 2004.

Price, Jennifer. Flight Maps: Adventures with Nature in Modern America. 1st ed. New York, NY: Basic Books, 1999.

Read, Richard T. "In Pursuit of Professionalism: The Oregon State Academy of Sciences, 1905-1914." Oregon Historical Quarterly 90, no. 2 (1989): 167-98. http://www.jstor.org.proxy.lib.pdx.edu/stable/20614242

Read, Richard T. "Institutionalizing Science in Oregon: The Role of the Oregon State Academy of Sciences, 1905-1914.” Master's thesis, Oregon State University, 1983. 
Reiger, John F. American Sportsmen and the Origins of Conservation. 3rd, Rev. \& Expanded, Ed., 1st OSU Press ed. Corvallis: Oregon State University Press, 2001. Robbins, William G. The Oregon Environment: Development vs. Preservation, 19051950, Corvallis: Oregon State University, 1975.

Robbins, William G. Landscapes of Promise : The Oregon Story, 1800-1940. Weyerhaeuser Environmental Book. Seattle, Wash.: University of Washington Press, 1997.

Russell, Ward, oral interview by Oliver P. Pearson (Berkeley, March 4, 1992), excerpt, Museum of Vertebrate Zoology, http://mvz.berkeley.edu/Grinnell_Method.html Rymon, Larry Maring, A Critical Analysis of Wildlife Conservation in Oregon, Oregon State University, 1969.

Shugart, Herman H. Foundations of the Earth: Global Ecological Change and the Book of Job. New York: Columbia University Press, 2014.

Snyder, Noel and Helen. The California Condor: A Saga of Natural History and Conservation. San Diego: Academic Press, 2000.

U.S. Environmental Protection Agency, DDT: A Review of Scientific and Economic Aspects of the Decision to Ban its Use as a Pesticide, EPA/540/1-75-022 (Washington D.C.: Environmental Protection Agency, 1975), 62-68. Walker, Charlotte Zoë. Sharp Eyes: John Burroughs and American Nature Writing. 1st ed. Syracuse, N.Y.: Syracuse University Press, 2000. 
Warren, Louis S. The Hunter's Game: Poachers and Conservationists in Twentiethcentury America. Yale Historical Publications. New Haven, CT: Yale University Press, 1997.

Wells, Kentwood D."What's in a Name? The Magic Lantern and the Stereopticon in American Periodicals 1860-1900," The Magic Lantern Gazette 20 (Fall 2008): 319.

Wilson, Alexander. The culture of nature: North American landscape from Disney to the Exxon Valdez. Cambridge, MA: Blackwell, 1992.

Wilson, Robert M. Seeking Refuge: Birds and Landscapes of the Pacific Flyway. Weyerhaeuser Environmental Book. Seattle: University of Washington Press, 2010.

Worster, Donald. Nature's Economy: A History of Ecological Ideas. Cambridge; New York, NY, USA: Cambridge University Press, 1994. 